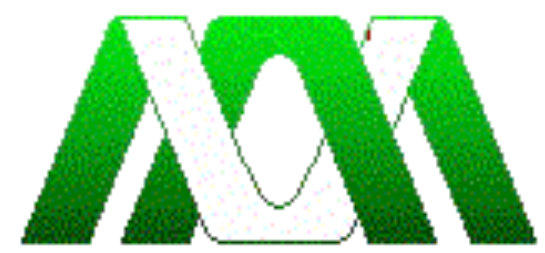

Casa abierta al tiempo

\title{
¿VÍCTIMAS O TRABAJADORES? \\ Niños jornaleros y producción \\ de subjetividades en el capitalismo tardío
}

Tesina que para obtener el grado de Maestra en Ciencias

Antropológicas presenta

Valentina Glockner Fagetti

Universidad Autónoma Metropolitana, Iztapalapa.

Directora: Dra. Margarita Zárate Vidal Asesor: Dr. Federico Besserer Alatorre Asesora: Dra. Adela Miranda Madrid

México, D.F., Junio del 2009 


\section{Agradecimientos}

Mi más profundo y sincero agradecimiento es para la Dra. Margarita Zárate Vidal, directora de esta tesina, y mis asesores: el Dr. Federico Besserer Alatorre y la Dra. Adela Miranda Madrid, sin cuya dedicación, consejos y observaciones a mi trabajo esta investigación no hubiera sido posible.

Agradezco también con mucho cariño a los integrantes del Equipo de Estudios Transnacionales de la Universidad Autónoma Metropolitana-Iztapalapa por haberme brindado su invaluable apoyo a través de sus ideas y comentarios teóricos y analíticos que enriquecieron mucho esta investigación.

Mi agradecimiento además al Consejo Nacional de Ciencia e Investigación CONACYT por la beca otorgada durante el periodo 2007-2009 para la realización de mis estudios de maestría y al proyecto número 91387 del fondo CONACYT denominado "Trabajo jornalero en Yurécuaro. Realización o negación", a cargo de la Dra. Adela Miranda, por prestarme apoyo logístico y económico para la realización del trabajo de campo en el estado de Michoacán.

A todos los profesores que durante este tiempo de formación me brindaron su asesoría y su apoyo, así como sus comentarios críticos y sus cuestionamientos.

A mis padres y a Daniel, desde luego y como siempre, por sostenerme en más de mil maneras.

Finalmente, mas no por último, agradezco mucho a Socorro Flores por su inestimable ayuda durante este par de años y por su generosa disposición para ayudarme en todo tipo de contratiempos. 
Mi experiencia con los niños indígenas migrantes comenzó en febrero del 2005 cuando a través del proyecto "Formación y fomento intercultural" que la Unidad de Culturas Populares e Indígenas del Estado de Morelos llevaba a cabo en una primaria urbana federal ubicada en la población de Oacalco, municipio de Yautepec, conocí a un grupo de niños indígenas mixtecos que habían migrado hacía varios años con sus familias a esa localidad para trabajar en los campos de fresa, pepino y jitomate.

Mi tarea comenzó siendo la de colaborar en el proceso de formación de una banda filarmónica donde niños indígenas mixtecos originarios de la región de La Montaña de Guerrero y niños mestizos nativos del municipio se encontraban para conocerse, integrarse y crear música. Mi propósito inicial se volvió entonces el de conocer mejor a esos niños, para poder así aportar algo significativo a la experiencia. Mi interés, mi asombro y mi acercamiento comenzaron siendo algo personal y cargado de emociones, pero pronto cobraron tanta importancia para mí, mi proyecto de vida y mi propio entendimiento de la labor antropológica que quise darle a ese interés, a ese cariño y a ese compromiso despertado por los niños un sustento y una profundidad teórica y etnográfica. El resultado fue mi tesis de licenciatura titulada: De la Montaña a la Frontera: identidad, representaciones sociales y migración de los niños mixtecos de Guerrero.

Aunque a lo largo de estos años me he ido haciendo más conciente -y espero que con mayor lucidez- del importante papel que las emociones han jugado en el origen y el desarrollo de mi investigación con los niños, así como sus implicaciones y repercusiones en la misma, a menudo he tenido que detenerme para intentar comprender esta condición de relación-trabajo y poder entender sus limitaciones y sus posibilidades tanto negativas como positivas; pero desde luego nunca he pretendido dejarla fuera, como muchos antropólogos para quienes la investigación y el trabajo de campo constituyen importantes prolongaciones de la experiencia humana y valiosas 
oportunidades de profundizar nuestro conocimiento de las sociedades y de nosotros mismos, así como de aprender acerca de las relaciones, el cariño y el compromiso.

En estos más de tres años en los que he mantenido un contacto constante con los niños Na Savi (mixtecos) de Guerrero, ya sea en sus comunidades de origen en La Montaña o en su "otro pueblo", conformado por los asentamientos relativamente recientes del norte de Morelos donde se han establecido junto con sus familias, he podido verlos crecer, terminar la primaria, incorporarse al trabajo jornalero a la par de los adultos, a algunos pocos comenzar la secundaria, o hacerse cargo de sus familias cuando el padre y/o los hermanos mayores han migrado; en suma, volverse adultos y, a veces, formar sus propias familias a lo que uno podría llamar la "prematura" edad de catorce o quince años.

Durante estos años he podido presenciar el nacimiento de más de una docena de hermanos y hermanas, la vuelta y el reencuentro con padres y madres migrantes a los que quizás ellos no conocían o de quienes guardaban sólo un vago recuerdo. Los he visto tener que marcharse a los Estados Unidos, habiéndose convertido en adultos durante de los nueve meses que toma la gestación de sus propios hijos, en busca del sustento y del sueño que persiguen tantos de sus paisanos y familiares. Los he visto tener que dejar atrás a sus propios hijos. Los he visto volver. A algunos con las manos vacías, a otros con algunos ahorros, todos llenos de anécdotas que contar, de experiencias que los han cambiado y fortalecido y que para algunos han sido determinantes para mantenerse aferrados al sueño de volver junto a los suyos -lo consigan o no- y que a otros les han hecho experimentar profundas contradicciones, a veces irreconciliables.

Durante todo este tiempo la experiencia de verlos crecer, desinteresarse por mis preguntas, por los juegos que antes jugábamos, los dibujos con los que antes me deleitaban, ha estado permanentemente acompañada de una preocupación por su bienestar y su futuro. Una preocupación que muchas veces me ha llevado a cuestionar mi propio papel como investigadora, como antropóloga, como ciudadana y como amiga. Una preocupación que me ha dado muchas más preguntas que respuestas y por la cual he decidido continuar mi investigación.

Ahora, varios años después de mi primer encuentro con los niños, y a la luz de una profundización teórica, puedo ver que tanto sus experiencias como las mías, son parte y producto del mismo momento histórico. Sus vivencias y sus preocupaciones, al 
igual que las mías, son producto de la modernidad, "llena de de paradojas y contradicciones", pues ambas nacen de un estar dominados "por las inmensas organizaciones burocráticas que tienen el poder de controlar, y a menudo de destruir, las comunidades, los valores, las vidas", pero también por un intento de "no vacilar en nuestra determinación de enfrentarnos a tales fuerzas, de luchar para cambiar su mundo y hacerlo nuestro" (Berman 1989:XI). Si algo he aprendido de los niños indígenas migrantes es que esto es posible y que "crear y asirnos a algo real aun cuando todo se desvanezca" no es una quimera. Desde luego con esto no quiero decir que nuestras formas de ser modernos o de insertarnos en la modernidad sean las mismas.

"Ser modernos es encontrarnos en un entorno que nos promete aventuras, poder, alegría, crecimiento, transformación de nosotros y del mundo y que, al mismo tiempo, amenaza con destruir todo lo que tenemos, todo lo que sabemos, todo lo que somos" (Berman 1989:1). En ese sentido los niños indígenas migrantes jornaleros son sujetos en pleno devenir, sujetos en tránsito que se construyen, crecen, aprenden y se enfrentan a las contradicciones y las terriblemente ambiguas y no siempre favorables posibilidades de la modernidad.

Y si como postula Berman (1989:XII) es "imposible captar y abarcar las potencialidades del mundo moderno sin aborrecer y luchar contra algunas de sus realidades más palpables", entonces mi interés y mi "preocupación" personalantropológica son las más modernas de las experiencias. Pero desde luego, también son una pregunta acerca de las posibilidades que tienen "los hombres y mujeres que son los sujetos tanto como los objetos de la modernización [...] de cambiar el mundo que está cambiándoles, abrirse paso a través de la vorágine y hacerla suya" (Berman 1989:2) para recuperar y valorar así sus propias maneras de ser modernos. 


\section{Introducción}

Cuando esté poquito grande ya me van a aceptar en el trabajo... Voy a trabajar en la fresa, o quién sabe, porque mi mamá quiere que sea doptor. Nomás que se necesita estudiar cómo.

\section{- Rodolfo, 9 años.}

\section{Por qué niños y por qué jornaleros}

A pesar de que existen amplios y muy numerosos estudios sobre el trabajo agrícola jornalero, las empresas agrícolas y la horticultura de exportación; la cuestión del trabajo infantil en este sector de la agricultura moderna de México ha sido todavía escasamente estudiado y son pocos los investigadores que han escrito textos extensos sobre este tema. Entre éstos cabe destacar los trabajos de Adela Miranda (2008), Kim Sánchez (2001 y 2005), Rodríguez Solera (2007) y Margarita Nemecio (2004 y 2006). No obstante, hacen falta todavía más estudios que documenten y examinen esta problemática, no sólo porque afecta directamente la vida de al menos un par de millones de niños en el país, sino porque sus características y desarrollo durante las últimas décadas exige de una reflexión sistemática y comprometida que profundice nuestro entendimiento del trabajo infantil como parte de la estructuración de una serie de procesos político-económicos de carácter global y como una estrategia más de adaptación del mercado laboral a las nuevas formas de producción y explotación del capitalismo tardío, al tiempo que reconozca la agencialidad de los niños jornaleros, el contexto socioeconómico de las familias y cree nuevos espacios para comprender su construcción como sujetos.

Hacer esto nos permitirá trascender ciertas discusiones y miradas simplistas que satanizan el trabajo infantil por juzgarlo como algo totalmente pernicioso, partiendo del análisis de uno de sus síntomas más vistosos, como la deserción y el fracaso escolar. Buscando aportar elementos para superar este atolladero, en esta investigación se pretende discutir la cuestión del trabajo infantil jornalero viendo más allá de éste, para 
enmarcarlo en el contexto histórico, político y económico que lo ha hecho posible y para señalar que el punto central de esta problemática no es el trabajo en sí, sino la explotación a la que estos niños son sometidos cuando participan en este tipo de trabajo agrícola.

Sabemos por las cifras de la Secretaría de Trabajo y Desarrollo Social que tan sólo en las plantaciones de exportación del norte del país se calcula que trabajan aproximadamente 900 mil niños jornaleros, que representan casi el 27\% del total de la fuerza de trabajo en este sector. Estos niños, que son sometidos a jornadas laborales que en ocasiones superan las ocho horas y que muchas veces no reciben un salario porque su paga es incluida en la raya de sus padres, tienen una tasa de mortandad que supera en un $24.4 \%$ a la media nacional, a causa de infecciones gastrointestinales y respiratorias que bien podrían curarse o prevenirse con atenciones médicas y servicios higiénicos básicos; o bien porque su inmadurez fisiológica los hace mucho más vulnerables a los efectos nocivos de los agroquímicos. Por si fuera poco, a esto debemos añadir los no poco frecuentes accidentes a los que los niños están expuestos en los campos debido a una convivencia cotidiana con maquinaria, camiones y herramientas que varias veces les han costado la vida. Finalmente, cabe añadir que los índices de mortandad se incrementan en el caso de los niños jornaleros indígenas debido también a sus peores condiciones nutricionales; y quienes además tienen un prácticamente nulo acceso a las de por sí escasas posibilidades de recibir una educación, de manera que para ellos su condición étnica constituye un factor más de vulnerabilidad y marginación.

Desafortunadamente, el fallecimiento de niños en los campos agrícolas no es un acontecimiento poco frecuente. Tan sólo en una temporada en los campos de Sinaloa, periodistas del Excélsior registraron el fallecimiento de 30 menores de edad (Turati et al. 2007). Sin embargo, normalmente estos casos no son dados a conocer debido a las presiones y amenazas que los dueños de las empresas o los contratistas hacen a los padres de los menores, normalmente indígenas monolingües, de que no volverán a encontrar trabajo en ningún campo de la región, forzándolos a firmar arreglos particulares donde eximen a la empresa de toda responsabilidad y aceptan indemnizaciones económicas mínimas (Ocampo 2007 y diarios locales como Suracapulco y El Diario de Chihuahua). 
A principios del 2007 y gracias a la intervención del Centro de Derechos Humanos de La Montaña Tlachinollan, se dio a conocer más ampliamente el caso del fallecimiento del niño nahua David Salgado de 9 años de edad luego de que fuera atropellado por un camión mientras cosechaba jitomates en Sinaloa junto con su hermano y sus padres. Lamentablemente en este caso, además de que la empresa lograra mediante las presiones de sus abogados que los padres analfabetas firmaran una exención de responsabilidad con la excusa de que el menor no tenía un contrato firmado, la Secretaría de Salud actuó como cómplice al emitir un acta de defunción que apunta que el niño había muerto por un traumatismo craneoencefálico en la vía pública (Tlachinollan 2007).

Resulta sobrado decir cuán importante es que la antropología se interese cada vez más por el papel que los niños indígenas juegan en el contexto de la migración jornalera y el trabajo en los campos agrícolas de exportación, avanzando en el entendimiento de la naturaleza de las relaciones sociales y económicas que éstos establecen en el marco de su participación laboral. Asimismo, es fundamental que cada vez más investigaciones tomen como centro de su interés a los niños migrantes y jornaleros con el propósito de ampliar nuestra visión y comprensión de éstos como individuos que tienen capacidad de acción en el contexto de las grandes estructuraciones político-económicas. También como un grupo de la sociedad que cada vez con mayor frecuencia está siendo sujetos de discursos y políticas públicas específicas, así como de nuevas estrategias de producción y de consumo, todo ello en una era caracterizada por un creciente individualismo y la búsqueda de individuos cada vez más flexibles, móviles y auto-regulados.

En esta investigación se hará, por lo tanto, un recorrido de los lugares que conforman la trayectoria migratoria de estos niños, participando en su construcción como sujetos y en la constitución de sus mapas vividos. Esto con el fin de examinar los procesos socio-históricos, simbólicos, económicos y políticos que han moldeado a los espacios vividos y transitados por los niños, con el fin de poder situarlos y entenderlos como una serie de espacios continuos o interconectados, atendiendo a las ideas expuestas por Gupta y Ferguson (1992) que expondré más adelante. Asimismo, se busca evidenciar el modo en que la subjetividad, las experiencias y la agencialidad de los niños son parte y producto de la emergencia y la transformación de estos espacios. 
Se retomarán algunas de las principales contribuciones de la antropología contemporánea sobre la infancia con el fin de llamar la atención y demostrar la pertinencia y la importancia de construir investigaciones antropológicas abiertas al cambio epistémico que una teorización sobre la infancia requiere y dispuestas a asumir los retos metodológicos que ésta postula.

Como señalan Blvebond-Langer y Korbin (2007:242), la popularidad de los estudios sobre la infancia ha ido creciendo en la antropología durante las últimas décadas en gran parte debido a la progresiva atención que han recibido los problemas globales de la infancia, generando la necesidad de estudiarla como un microcosmos cuyos problemas conciernen, están vinculados y son producto de todas las sociedades.

Como ha sido el caso con otros grupos sociales, raciales o de género, la antropología de la infancia también ha hecho un llamado de atención sobre la importancia de no producir conocimientos parciales que respondan a conceptos universalistas, concepciones homogeneizantes, y a no asumir modelos o posturas preconcebidas, teleológicas o adultocéntricas. Por lo tanto, la antropología contemporánea de la infancia postula por la comprensión de los niños como actores constructores de significado, con capacidades específicas y situados en planos de experiencia multifacéticos, y donde coexisten la vulnerabilidad y la agencia. Entonces, al igual que sucede con la clase y el género, la infancia debe ser pensada y teorizada como una categoría cultural, sujeta a determinadas relaciones de poder y a diversas interpretaciones y que, por lo tanto, posee un enorme potencial para la investigación.

Por lo tanto, cuando se trabaja con niños, es indispensable tomar en cuenta todo lo siguiente: "selectivity of representation, uncritical quoting, polyphony of voices, whose point is being made, and whose agenda is being served". El reto está entonces en no limitarnos a documentar las voces de los niños, sino en acompañar sus testimonios con una reflexión acerca del modo en que lo que están diciendo se sitúa y se enmarca en un contexto más amplio y complejo, prestando atención a las constricciones sociales y culturales que operan en el momento de la investigación. Esto nos permite ver cómo la antropología de la infancia se origina y tiene sentido más allá de su ámbito, brindando a la disciplina antropológica nuevas posibilidades teóricas, heurísticas y metodológicas. Así pues, "el estudio etnográfico de la niñez sirve no sólo para debatir teorías y orientaciones dominantes, sino para modificar y corregir ideas establecidas acerca de 
las vidas cotidianas y las experiencias de los niños" (Blvebond-Langer y Korbin 2007:243245) en sociedades cada vez más multivocálicas y democráticas. 


\section{Pobreza, desarrollo y trabajo jornalero}

\section{Sujetos móviles y multi-situados}

En este primer apartado se expone y argumenta la idea de que un estudio de las experiencias infantiles de migración y trabajo jornalero que parta de una conceptualización de los mismos como sujetos móviles y multi-situados en el marco de vastos procesos económicos, sociales y políticos, nos permitirá lograr una comprensión más compleja del modo en que sus vidas están articuladas e interconectadas con fenómenos locales, nacionales y globales de diverso alcance y profundidad, que no sólo determinan y transforman sus vidas, sino que les proporcionan marcos para la acción como individuos y como miembros de una comunidad.

Siendo así, a lo largo de esta tesina se hará una revisión de los lugares, geográficamente discontinuos, en los que los niños indígenas jornaleros crecen, se socializan y se desenvuelven acompañando a sus familiares en la ruta migratoria y compartiendo con ellos la responsabilidad de la supervivencia económica. Comenzaremos con la región de La Montaña de Guerrero, una de las zonas de mayor expulsión jornalera del país. Revisaremos luego algunos aspectos de los campos jornaleros, tomando como base mi propia experiencia en Morelos y la bibliografía sobre Sinaloa, con el fin de comprender, por una parte, cómo se han generado a lo largo de los años las condiciones socioeconómicas y políticas que han llevado a miles de familias campesinas a prácticamente no tener otra opción para sobrevivir que la de emplearse en el trabajo agrícola jornalero, caracterizado por ser mal pagado y explotador; y por la otra, comprender cómo esta migración precaria y vulnerante se genera para adaptarse a las nuevas exigencias de la producción posfordista.

He decidido hacer este recorrido porque a partir de sus experiencias itinerantes entre sus comunidades de origen en la sierra de Guerrero, los campos jornaleros y, algunas veces, los Estados Unidos, los niños migrantes conectan y unen todos estos 
lugares, lejanos entre sí, para conformar su geografía personal y su propio mapa de lo vivido, que posteriormente les permitirá trazar y entender su propio lugar en el mundo. Se parte entonces de una visión "microhistórica" que nos permite entender que "cada ser humano representa y manifiesta su propia historia" con la cual da sentido al mundo, entrelazando los sentidos que los otros han construido para él y los que él construye para sí mismo (Toren 2007).

Se propone por consiguiente trabajar sobre un "modelo de articulación" como postulan Gupta y Ferguson (1992), que nos permita pensar a los niños como actores móviles y sujetos de procesos y acontecimientos que tienen lugar no en paisajes socioculturales fragmentados e independientes, sino en espacios "jerárquicamente interconectados", lo cual nos abre la posibilidad de develar y analizar mejor las características y el funcionamiento de las "topografías del poder".

Al ser pensadas dentro de un modelo de cambio cultural donde lo local se relaciona dialécticamente con escenarios espaciales mayores (Gupta y Ferguson 1992), las experiencias de vida de los niños jornaleros migrantes cobran un mayor sentido como "ventanas" o puntos de inflexión a partir de los cuales nos es posible comprender fenómenos tan intrincados como el éxodo campesino, las cadenas de producción posfordista o la explotación capitalista del mercado laboral agrícola contemporáneo; al tiempo que logramos un entendimiento más vasto de las transformaciones acaecidas en los escenarios locales, nacionales y globales, o bien en las formas de experimentar y vivir cada una de estas dimensiones en un constante ir y venir entre ellas.

Se postula entonces la pertinencia de pensar a los niños jornaleros como sujetos multi-situados, puesto que si los observamos y conceptualizamos solamente como sujetos pertenecientes a una comunidad determinada, localizada en un escenario geográfico específico, fracasaremos desde un comienzo al examinar la profundidad de los procesos en los que se encuentran inmersos. Por lo tanto, estos niños indígenas son habitantes de comunidades Na Savi de la Montaña de Guerrero, pero son también migrantes itinerantes, en constante ir $y$ venir de sus comunidades a los campos jornaleros y a las pequeñas urbanizaciones de los Estados Unidos donde sus padres se emplean en las plantas procesadoras de alimentos. Incluso su propia condición de sujetos en pleno desarrollo biológico y social hace de estos niños sujetos múltiples, en 
tanto que viven y se apropian de manera distinta de cada uno de los lugares que visitan dependiendo también de la edad que tenían cuando estuvieron allí y del rol que de acuerdo a ello y al nuevo contexto sociocultural les fue asignado al interior de su familia.

Como postulan Gupta y Ferguson (1992:9), en el contexto pulverizado de la posmodernidad, el espacio no se ha vuelto algo irrelevante, sino que ha sido reterritorializado de un modo que nos obliga a reconceptualizar la política de la comunidad, la solidaridad, la identidad y la diferencia cultural. En este mundo reterritorializado, la movilidad veloz y expansiva de la gente se hace acompañar de una aparente des-territorialización de la identidad que lejos de denotar una pérdida de las raíces territoriales o la erosión de la distinctividad cultural de los lugares, nos obliga a preguntarnos sobre los procesos -más que sobre las esencias- que están involucrados en las experiencias de la identidad cultural.

En un mundo donde las identidades están siendo cada vez más desterritorializadas, la idea de una conexión natural y esencial entre el lugar y los sujetos o las culturas está siendo cada vez más cuestionada y problematizada. La ironía, y lo interesante, como señalan Gupta y Ferguson (1992:10), es que a medida que las conexiones entre comunidades y lugares se tornan más inasibles, y estos se vuelven cada vez más borrosos e indeterminados, la idea de la existencia de localidades cultural y étnicamente distintas se vuelve todavía más importante, en tanto que la erosión de las conexiones supuestamente naturales entre culturas y lugares de ninguna manera nos ha llevado a una homogeneización modernista y global de la cultura.

Por lo tanto, siguiendo a estos autores, podemos decir que ahora se vuelve cada vez más importante estudiar los procesos mediante los cuales los migrantes se apropian y construyen sus propios lugares de pertenencia a través de sus vivencias, sus prácticas cotidianas, sus recuerdos y su imaginación, sin importar si éstos son un lugar 'de origen', 'de paso' o 'de permanencia'. Asimismo, resulta fundamental estudiar los procesos económicos, políticos y sociales a partir de los cuales estos lugares se crean y se transforman en un mundo "globalmente interconectado" (Gupta y Ferguson 1992:11), y sin olvidar el profundo "bifocalismo" que caracteriza a las existencias vividas en el plano de lo local y el poderoso papel que juega el lugar en la experiencia vivida; o de cómo se articula todo esto con la fuerte espacialización que caracteriza a la economía 
global capitalista pues, finalmente, los lugares son imaginados siempre en el contexto de determinaciones político-económicas concretas que responden a su propia lógica.

Todo esto, desde luego, nos abrirá nuevas perspectivas tanto teóricas como metodológicas para el trabajo con los niños indígenas migrantes, en tanto que nos ofrece otras perspectivas sobre la representación, la objetivación y la escritura antropológica. El objetivo entonces es ir más allá de las concepciones naturalizadas de las culturas, las colectividades y los sujetos para explorar la producción de la diferencia y la exclusión en "espacios comunes, compartidos y conectados" (Gupta y Ferguson 1992:16) en el marco de relaciones de poder específicas. Así también se debe resaltar la importancia de lo vivido y de la imaginación en la experiencia de los lugares y en la construcción de mapas íntimos cuya principal virtud es precisamente mostrar las interconexiones que existen entre lugares aparentemente discontinuos.

\section{La geografía de la pobreza: La Montaña de Guerrero}

La Montaña de Guerrero es una de las regiones catalogadas como de "más alta marginación" en México. En el 2005 el Programa de las Naciones Unidas para el Desarrollo (PNUD) determinó que el municipio Na Savi de Metlatónoc' era el más subdesarrollado del país por sus altos índices de marginación, mortandad, desnutrición y pobreza, y por poseer un Índice de Desarrollo Humano equiparable al de Malawi, en África (ver Nemecio 2006 y Ocampo 2005).

Los factores que han contribuido a que esto sea una realidad mesurable que cada año expulsa a miles de familias indígenas en un éxodo migratorio que comprende los campos jornaleros del centro y el norte del país y varios estados de los Estados Unidos, son múltiples y complejos. Entre ellos podemos citar, brevemente, décadas de políticas gubernamentales erradas o negligentes para el campo y la población indígena, un grave deterioro ecológico y la supeditación de la economía campesina a la economía capitalista global.

Ya desde la década de los 50's Alfonso Fabila, César Tejeda, Maurilio Muñoz y Salomón Nahmad alertaban sobre la delicada y precaria situación ecológica y socioeconómica de la región denominada Mixteca-Nahua-Tlapaneca (Muñoz 1963)

\footnotetext{
${ }^{1}$ A este municipio pertenecen los niños jornaleros migrantes con los que se realizó la presente investigación.
} 
donde, como su nombre lo indica, habitan un gran número de indígenas Na savi (mixtecos), Nahuas y Me'phaa (tlapanecos) y que abarca los distritos de Morelos, Álvarez y Zaragoza, en el actual estado de Guerrero.

Para el año de 1963 el antropólogo Maurilio Muñoz indicaba que las condiciones socioeconómicas de la población de esta región se mantenían "casi en la misma situación que durante la Colonia" (Muñoz 1963:35). Entre las causas se cuentan una indiscriminada explotación de los bosques y otros recursos naturales, y un mal aprovechamiento de los suelos, la fauna y los recursos minerales disponibles. Lo primero por el otorgamiento de derechos de explotación de los bosques a empresas madereras y aserraderos pertenecientes a particulares con intereses ajenos a las comunidades y que han terminado con más del 60\% de los recursos forestales (Canabal 2001:30). Lo segundo por varias razones: la presión que el rápido crecimiento demográfico ha ejercido sobre las tierras de labranza², por la escasez y la precariedad de las mismas, por la preeminencia del riego de temporal, así como por la falta de apoyos y capacitaciones a los campesinos para hacer frente a la erosión y la baja productividad. Canabal (op. cit) reporta que ya entre 1988 y 1990 Banrural había reducido $85 \%$ el financiamiento del maíz en Guerrero y en 1990 nueve de cada diez maiceros no recibieron crédito oficial. Posteriormente, el financiamiento de Pronasol tampoco alcanzó a cubrir el monto ni la extensión de tierra que antes beneficiaba Banrural.

A esto debemos añadir la drástica y sostenida explotación de sus recursos forestales desde la época de la Colonia, cuando las haciendas volantes hacían pastar en el territorio indígena de La Montaña hatos ambulantes de hasta 400,000 cabras, pagando una renta mínima a las comunidades que atravesaban y en un tránsito que iba desde Puebla hasta la costa del Pacífico (Dehouve 2001:64, 69). Al finalizar la Colonia, la exportación de madera creció para sustituir dos productos típicamente coloniales: la cochinilla y la manta. En la región de La Montaña esta explotación se mantuvo constante aunque en menor escala que la de los bosques de Chihuahua, por ejemplo, debido a la falta de comunicaciones. No obstante, hoy que los habitantes mestizos de Tlapa acusan a las comunidades indígenas de haber destruido los recursos

2 Según Beatriz Canabal (2001:30) la población se ha cuadruplicado en la región de La Montaña entre 1921 y 1990, y el rendimiento de la tierra ha decaído hasta en un $50 \%$. 
naturales de su hábitat al emplear técnicas agrícolas como la roza y quema o tlacolol, olvidan que estos bosques han estado sujetos a la explotación desde el siglo XVI (Dehouve 2001:242).

A principios de los 60's Muñoz (1963:49-50) escribía que la región había llegado al "límite del aprovechamiento de los recursos agrícolas disponibles", siendo que de los 1.2 millones de hectáreas de cerros, barrancas y lomeríos que la conforman, sólo el 25\% es o era- útil para la agricultura, en su mayoría de temporal. Asimismo señala que la zona de Metlatónoc era la mejor dotada de montes para la agricultura y pastizales para la ganadería que, aunque precarios, permitían un modesto desarrollo de la crianza de animales. No obstante, la apertura de la mayoría de las 53,220 hectáreas que Muñoz menciona como susceptibles de ser utilizadas para estos fines, se debía hacer afectando los bosques.

De manera que hoy el deterioro ecológico de esta región montañosa a menudo es citado como "alarmante" a causa de graves procesos de erosión, contaminación de ríos y mantos freáticos, deforestación, cambios de uso de suelo, incendios y plagas forestales, depredación de flora y fauna, y un precario tratamiento de residuos sólidos; a lo cual se suma un $43.2 \%$ de pérdida de la vegetación natural (Chávez Román 2004:32-33).

Ya en 1996 el volumen de la producción de maíz en la Montaña había sido el más bajo del estado de Guerrero con 33,299 toneladas, por lo que no alcanzó a satisfacer la demanda local estimada en 80,000 toneladas al año (Canabal 2001:33). Los campesinos se tornaron aún más dependientes de la compra de maíz proveniente de otras regiones e incluso importado, a pesar de que en el mismo año el $68.4 \%$ del total de las tierras cultivables se dedicaban a este grano según datos de Beatriz Canabal.

El excelente trabajo etnohistórico de Danièle Dehouve (2001) nos ayuda a comprender los motivos por los cuales las comunidades indígenas han llegado a esta condición de precariedad, mostrándonos que la historia de la región de la Montaña donde se ubican los municipios indígenas que nos interesan, es decir la provincia de Tlapa- ha estado marcada por una casi continua condición de sujeción social y económica. En primer lugar debido a la conquista azteca y el correspondiente pago de tributos a dicho imperio que tuvo lugar durante la época prehispánica, y posteriormente a causa de la repartición de sus riquezas en una encomienda y un 
corregimiento, y por la constante explotación por parte de las haciendas ambulantes que sacaban provecho de sus tierras sin cultivar. Las divisiones establecidas al final del siglo XVI determinaron que la provincia de Tlapa quedaría sujeta a la diócesis de Puebla gracias a que los españoles establecidos en la meseta central del país se encontraban "en una situación comparable a la de los aztecas" (Dehouve 2001:33), buscando el control de las rutas de acceso hacia las tierras tropicales del sur de México.

Los beneficios económicos del saliente papel de Tlapa como lugar de paso estratégico entre La Montaña y La Costa fueron grandes, aunque desde luego nunca estuvieron en manos de los indígenas de la región, sino de los alcaldes, intendentes y españoles que controlaban el comercio y el tránsito por su territorio. Esta preeminencia comenzó a ser minada cuando la evolución económica de la región durante el siglo XVIII sentó las bases para reorganización administrativa y el surgimiento de grandes centros comerciales en La Costa. Por lo tanto, para el siglo XIX, Tlapa figuraba como una zona poco desarrollada y atrapada entre dos grandes polos comerciales: Puebla al norte y La Costa al sur (Dehouve 2001:35).

Luego de la fundación en 1849 del estado de Guerrero y de que Tlapa se le adhiriera, ésta comenzó a ver reducidos constantemente sus límites territoriales, quedando mermada y debilitada en importancia y extensión, dado que su jerarquía se basaba, desde la conquista azteca, en su condición de intermediaria entre la meseta central y la costa del pacífico (Dehouve 2001:36).

A esto se debe añadir la dramática disminución de la población indígena durante los siglos XVI y XVII, a causa de las terribles epidemias que se extendieron por toda la Nueva España. Se calcula que la mortandad fue de entre el 30 y el $76 \%$ de la población, alcanzando en algunos lugares hasta el $98 \%$. El impacto social y económico de esta merma demográfica se veía incrementado por el hecho de que el número de muertos no se restaba a los censos de tributarios y por lo tanto el monto de los tributos que cada pueblo debía entregar a la corona española no disminuía (Dehouve 2001:4548). Por otra parte, la presencia cada vez mayor de haciendas en esta región contribuyó a empeorar aún más esta situación en tanto que, en la medida en que los caciques se apoderaban de extensiones cada vez más grandes de tierras 
originalmente propiedad de los indígenas, varios pueblecitos y rancherías iban desapareciendo (Dehouve 2001:52).

Dehouve relata que no obstante esto, desde el siglo XVIII la región de Tlapa presentaba ya "un aspecto completamente moderno" y que la región de La Montaña se diferenciaba fuertemente de La Costa por el "peso de su indianidad", pues hasta el censo de 1745 la población de, por ejemplo el municipio de Metlatónoc, todavía era puramente indígena, al contrario de otras parroquias donde comenzaba a darse la presencia de algunas familias de españoles y mestizos (Dehouve 2001:49,52).

Sabemos entonces que desde la primera mitad del siglo XVI y durante casi todo el siglo XVII se consolidó una fuerte diferencia entre la región de La Montaña y la de La Costa, que desde un principio fue privilegiada por los españoles por sus ventajas productivas para la caña de azúcar, el cacao y el ganado. Aunque todavía hasta comienzos del siglo XVIII las haciendas y el capital privado vieron restringido su crecimiento por la propiedad indígena de la tierra, tanto en La Montaña como en La Costa, esta situación habría de llegar a su fin a mediados del siglo XIX cuando los hacendados comenzaron a apropiarse de las tierras comunales (Dehouve 2001:62-63).

Pero mucho antes de esto, con el cobro de rentas por las tierras utilizadas para el pastoreo por las haciendas ambulantes y la prestación de "servidumbres" por parte de los indígenas que debían trabajar para los hacendados y cuyas tierras sufrían constantes daños por el paso de los animales, los pueblos indígenas quedaron marcadas por constantes conflictos agrarios intercomunitarios que se extendieron durante todo el siglo XVIII y que debilitaron gravemente la cohesión regional. Los hacendados, buscando tierras cada vez más baratas azuzaron y multiplicaron estos conflictos, interviniendo en las pugnas locales y agudizando sus contradicciones internas (Dehouve 2001:65-66).

Durante el siglo XIX las haciendas se extendieron en La Montaña al igual que en el resto del país, casi siempre a costa de las tierras comunales indígenas y aprovechando los conflictos que los caciques tenían con los locales para extenderse también sobre sus propiedades que solían incluir varios pueblos. El extremo de esta situación se dio cuando los indígenas de Zitlaltepec fueron obligados a pagar una renta anual al hacendado mientras que éste utilizaba a su gusto los pastizales que había acaparado (Dehouve 2001:70). 
A mediados del siglo XIX la nueva legislación "liberal" denominada Ley de Desamortización o "Ley Lerdo" redujo a cenizas la relativa inmunidad que la propiedad comunal de las tierras había concedido a los indígenas y el proceso de extensión de las haciendas se aceleró. Aunque en Tlapa el primer efecto de esta Ley fue permitir la extensión de las haciendas sobre las propiedades eclesiásticas, en una segunda etapa en 1869, la legislación puso en peligro los bienes comunales indígenas al permitir la adjudicación de los terrenos no cultivados y posteriormente permitiendo la desamortización de los bienes comunales para el otorgamiento de títulos de propiedad privada (Dehouve 2001:70-72).

No obstante los pueblos de La Montaña, "que mantenían una fuerte cohesión interna, escaparon a esta regla y utilizaron la privatización de las tierras como un simple artificio jurídico a fin de asegurar la salvaguardia de los bienes comunales". Cuando llegó la Revolución, ésta logró desaparecer la única hacienda de importancia que había logrado construirse en La Montaña, antes propiedad del empresario poblano Guillermo Ancho y que había sido vendida al estadounidense Lewis Lamm. Para 1940 la reforma agraria había reestablecido en La Montaña la situación prevaleciente hasta antes de que en el siglo XIX las haciendas ambulantes amenazaran la continuidad de las comunidades indígenas (Dehouve 2001:72-73).

Sin embargo, Dehouve (2001:291) señala que "la lentitud de las evoluciones económicas y sociales de la sierra de Tlapa en la primera mitad del siglo XX es sorprendente", pues cuando ella llegó a la región en 1967 encontró una sociedad regional quizá muy parecida a la del comienzo de la Revolución, por mantener todavía algunos rasgos como "la explotación de la población indígena por los comerciantes mestizos de Tlapa, y la práctica generalizada de la compra "a tiempo", un sistema de habilitaciones manejado por un número limitado de revendedores indígenas en los pueblos, así como la sobrevivencia de perjuicios de "castas" que se expresaban por ejemplo en las limitaciones raciales de acceso al único restaurante de la ciudad. "En la sierra las comunidades conservaban un funcionamiento originado en el porfiriato y, más allá, en el periodo colonial tardío".

La casi permanente condición de precariedad e inestabilidad que a lo largo de los siglos ha caracterizado al modo de subsistencia agrícola de los indígenas de La Montaña ha hecho que éstos desarrollaran y se apoyaran en la producción de diversos 
productos artesanales, principalmente a partir de la palma. No obstante, y como menciona Muñoz (1963:89) debido a que ésta no crece en la región que los indígenas habitan, su dependencia de los intermediarios, tanto para la provisión de la materia prima como para la comercialización del producto final, es doblemente onerosa. Aún así, Muñoz señala que en 1963 el total de los 48,762 habitantes del distrito de Morelos (al que pertenece Metlatónoc) dependían económicamente la elaboración de sombreros de palma.

Actualmente en las comunidades $\mathrm{Na}$ savi o mixtecas del municipio de Metlatónoc la fabricación de sombreros sigue siendo una actividad económica de suma importancia para las familias que han perdido la capacidad de la auto subsistencia alimentaria, mucho más todavía para las que no reciben ingresos de familiares en Estados Unidos o para los ancianos que se han quedado solos luego de que sus hijos se marcharan o formaran sus propias familias. Nemecio (2004) menciona que en varias comunidades de la Montaña Alta y Baja la importancia de esta actividad sigue siendo enorme para completar los magros ingresos de la agricultura y que la participación de las niñas es fundamental, en tanto que representan mano de obra "desocupada".

Resulta desalentador notar que siendo una actividad importante en La Montaña la producción de sombreros sigue siendo realmente mal remunerada. En las comunidades Na Savi de Atzompa o Yuvinani, por ejemplo, la docena de sombreros terminados tal y como lo requieren los intermediarios que los transportan a Tlapa se vende a 23 ó 25 (22 ó 26 pesos para las comunidades estudiadas por Nemecio 2004:117), cuando su elaboración puede tomar de dos a tres semanas, dependiendo del tiempo que se le dedique y si es temporada de lluvias o secas. No obstante, el "ciento" de palma puede costar entre 18 y 30 pesos (que alcanza para dos docenas), por lo que la producción debe ser veloz y abundante.

El rendimiento promedio de esta actividad apenas ha variado desde el tiempo en que Muñoz escribía su etnografía. Más preocupante es ver que tampoco ha variado desde 1936, época en que Pauzic recorrió la región de Tlapa, cuando el sombrero tlalpeño representaba el 87\% de la producción en La Montaña, ni cuando en 1967 Dehouve encontró que el precio por sombrero oscilaba entre los 25 y los 50 centavos, por lo que estos ingresos no eran suficientes ni siquiera para que las familias adquirieran 
la cantidad mínima de maíz para la subsistencia, siendo la proporción entre salario/horario una de las más bajas que existen (Dehouve 2001:294).

Finalmente, el extraordinario crecimiento poblacional iniciado con el siglo XX constituyó la punta de lanza que terminó de volver irremediable la presión sobre las limitadas y agotadas tierras comunales de La Montaña, por lo que los campesinos comenzaron a vender sus cosechas mucho antes de que éstas maduraran a causa de la anticipada escasez de maíz. Pauzic (citado en Dehouve 2001:300) calculaba ya en 1936 que los campesinos perdían cerca de 60,000 pesos anuales por la venta anticipada de su maíz a un precio 4.5 veces menor a lo que ellos lo adquirían en los mercados de Tlapa. Cabe señalar también que a finales de la década de los 90's Beatriz Canabal (2001:37) encontró que ésta continuaba siendo una práctica recurrente de los campesinos montañeros quienes, por la acelerada pérdida de los suelos y la falta de apoyos económicos y técnicos, muchas veces tenían que recurrir también a prestamistas locales o al préstamo en grano.

Este tipo de acaparamiento y especulación resultaba sobre todo beneficioso para las élites españolas, que todavía en la década de 1950 controlaban el comercio entre Tlapa y otras provincias, gobernando la ciudad y conservando celosamente sus privilegios. Paralelamente a esto las cofradías religiosas indias, ahora llamadas Mayordomías, continuaron siendo poderosos auxiliares del comercio regional. Aumentaron así en número y capital, adaptándose a las nuevas actividades de producción y en ocasiones prestando a los campesinos el capital de los santos con tasas de interés de hasta del 100\% (Dehouve 2001:299-301).

Los municipios de La Montaña conquistaron su plena autonomía agraria en el siglo XX gracias al desinterés mostrado por el Estado respecto al problema de la tierra. No obstante las comunidades indígenas continuaron siendo presa fácil de personas acomodadas y bilingües que bajo el puesto de "secretarios" perpetuaron su control sobre éstas, como fue el caso de Metlatónoc. Pero aunque aislados y mal comunicados, los indígenas estaban muy bien integrados en el sistema político que los controlaba mediante una jerarquía de pequeños y medianos caciques y en el que el sistema de cargos local jugaba un importante papel (Dehouve 2001:304-308).

Todo esto dio lugar al panorama idóneo para que en 1950 la introducción de una "verdadera actividad asalariada" de tipo temporal como la migración agrícola 
jornalera se generalizara en toda la región de la Montaña. Los indígenas comenzaron entonces a ser enganchados en las ciudades de Tlapa y Chilapa para ser transportados a las grandes plantaciones de Morelos para cosechar jitomate, caña de azúcar y café (Dehouve 2001:295). En este momento se abría una ruta para la migración estacional que hoy se ha extendido a plantaciones tan remotas como las de San Quintín en Baja California, y que continúa siendo fundamental para la supervivencia de miles de familias indígenas empobrecidas de La Montaña, principalmente para aquellas para quienes por su misma condición de extrema precariedad económica o por la falta de redes sociales de apoyo, la migración internacional no representa una opción viable para asegurar su subsistencia.

Canabal (2001:42) señala que en 1970 el 14\% de la población total del Estado había migrado, llegando a constituir casi el $20 \%$ en 1990, según datos del INEGl. Asimismo se sabe que el estado de Guerrero ocupa el primer lugar en el índice de migración interna de México, pues más de 128,000 jornaleros agrícolas se trasladan cada año a Sinaloa, Sonora y Baja California (SIPAZ), destacando La Montaña como la principal expulsora de indígenas jornaleros de la entidad (Sánchez 2001:85). Además, Guerrero ocupa el quinto lugar en cuanto a migración internacional en tanto que alrededor de 73,000 guerrerenses emigran cada año a Estados Unidos (INEGI 2000) y se calcula que actualmente cerca de 950,000 de sus ciudadanos viven en aquél país (SIPAZ).

Resultado de los procesos de intervención del Estado y las transformaciones socioeconómicas que marcaron al siglo XX, las comunidades indígenas se fueron caracterizando por una reducción en su tamaño y por la importancia otorgada al trabajo colectivo en pro de la modernización. A finales de los años 70 los anhelos de modernidad regían todas las decisiones y los conflictos regionales. Además, Dehouve (2001:324) describe cómo los interminables conflictos oponían a los grupos sociales debilitando a la comunidad, que ya no se presentaba poderosa y unificada frente las comunidades vecinas. Su sistema político religioso se reestructuraba según las prioridades del momento.

Lo valioso del trabajo de Dehouve (2001:328) es que nos muestra que la comunidad indígena es una "institución compleja multiforme y multifuncional" que ha servido a los más diversos intereses, privados y comunales, desde su invención durante 
la Conquista española y su imposición como forma de vida a las poblaciones autóctonas. Posteriormente, durante la época de la Colonia, su relación con el desarrollo del capitalismo se modificó profundamente con el fin de "lograr al mismo tiempo la evangelización, la integración política y la inserción económica de los indios en la sociedad colonial". Las relaciones con el capital pasaban ahora por intermedio de ciertas capas del campesinado que poseían el poder comunal, por lo que la comunidad indígena "en sus instituciones, en sus prácticas políticas, sus contornos incuso, representó a la vez el marco y el reto de las estrategias económicas campesinas [...] Así, la aparente sobrevivencia de una misma forma de la organización social recubre en realidad un proceso ininterrumpido de transformaciones y adaptaciones a las etapas sucesivas de desarrollo del mercado mundial".

Hoy, La Montaña de Guerrero se ha convertido en una de las zonas más marginadas del país, de lo cual, sus altas cifras en mortandad materna y desnutrición infantil son sólo un indicador. Según datos citados por Nemecio (2004:68), actualmente en La Montaña el $83.9 \%$ de la población es analfabeta, sólo el $67 \%$ de las localidades cuenta con servicios educativos, los servicios de salud cubren sólo al $68 \%$ de la población con un médico para cada 1,956 habitantes y una cama para cada 8,672, cifras muy inferiores a las mínimas recomendadas por la OMS. Además, en Guerrero la mortandad materna entre las mujeres indígenas es de las más elevadas en el mundo, pues mueren 281 por cada 100,000 recién nacidos mientras el promedio nacional es de 151 y de 51 en las mujeres mexicanas (SIPAZ)

Abel Barrera, director del Centro de Derechos Humanos de la Montaña Tlachinollan resume la situación actual de la siguiente manera: "ahí viven unos 300.000 indígenas, pobres de los más pobres (incluyendo los dos municipios más pobres del país), hay droga, hay militares y hay migrantes pero no hay de qué comer [pero] también ahí se gestan movimientos de resistencia: por la educación, por la salud, por la defensa de los derechos de los migrantes." 3

${ }^{3}$ Citado en la página web del Servicio Internacional para la Paz (SIPAZ): http://www.sipaz.org/fini_esp.htm 


\section{Pobreza y subdesarrollo: la construcción de un sujeto}

La intervención del Estado en la geografía social y económica de las comunidades indígenas de La Montaña comenzó en 1964 a través del Instituto Nacional Indigenista (Dehouve 2001:309), el que más adelante sería asistido por otras numerosas dependencias del gobierno. Siendo su principal objetivo la modernización de las comunidades indígenas para incorporarlas al progreso de la economía y la cultura nacionales, durante varias décadas el INI construyó vías de comunicación terrestres y aéreas, estableció redes telegráficas y eléctricas, introdujo cooperativas, abrió tiendas para la comercialización de los productos campesinos, construyó escuelas-albergues, y capacitó y contrató cientos de promotores indígenas.

Por medio de éstos últimos en particular el Estado hizo fluir a las comunidades grandes cantidades de dinero destinadas a las familias montañeras, que ya a finales de los 70's comenzaron a experimentar los beneficios de las primeras transferencias económicas periódicas como pago por el trabajo de sus hijos promotores. Una transformación particularmente importante para familias campesinas habitualmente desprotegidas ante la insuficiencia crónica de ingresos por el trabajo agrícola (Dehouve 2001:311-312).

Poco hacía falta para que lo que el INI juzgaba como el "atraso" social y económico en el que supuestamente vivían las comunidades indígenas del país fuera internacionalmente reconocido como "subdesarrollo". Concretamente, una serie de decisiones tomadas entre 1945 y 1955 por parte de los países industrializados en el marco de las transformaciones sociopolíticas y económicas de la posguerra. Así se delinearon los conceptos a partir de los cuales Occidente se redefiniría a sí mismo y a sus estructuras globales de poder con respecto al desde entonces llamado "Tercer Mundo", y el "subdesarrollo" proporcionó el marco conceptual y discursivo para ello (Escobar 1988:429).

Tan pronto como 1949, el Banco Mundial -uno de los principales instrumentos para el desarrollo económico y la liberalización del comercio junto con el Fondo Monetario Internacional-, ya se encontraba ensayando sus primeros programas de Desarrollo en Latinoamérica e introduciendo la ahora clásica retórica del "círculo vicioso de la pobreza", tan socorrida en México por los programas de transferencias 
económicas condicionadas iniciados durante el sexenio de Carlos Salinas de Gortari, y constantemente mencionada por el PROGRESA (Programa de Educación Salud y Alimentación) de Ernesto Zedillo ${ }^{4}$ y el Oportunidades de los dos últimos gobiernos panistas.

A grandes rasgos y en un nivel macro, el discurso del subdesarrollo tenía como objetivo crear una sociedad equipada con los factores materiales y organizacionales requeridos para facilitar el rápido acceso a las nuevas formas de vida creadas por las sociedades industrializadas. El objetivo: crear nuevas oportunidades de inversión en el extranjero y nuevos mercados para los productos de los países industrializados (Escobar 1988:429-430). Adaptado al contexto del "Tercer Mundo" y visto a nivel del discurso social puesto en marcha por los gobiernos mexicanos, el mito del desarrollo se tradujo en programas que partían, como señalan Favela et al. (2003:39), del "concepto teórico y práctico de que las capacidades básicas de los individuos son el punto básico que debe armonizar la productividad y la remuneración de las actividades económicas con el derecho de una vida digna".

Correspondía entonces al gobierno dotar a los individuos de las herramientas básicas, para que luego éstos pudieran transformar positivamente sus condiciones de alimentación e higiene, logrando un mejor desempeño educativo y rompiendo con el "círculo vicioso de la pobreza", la ignorancia, la enfermedad, la insalubridad y la desnutrición "que tiene atrapados a muchos millones de mexicanos en la pobreza" (Zedillo 1997). El ansiado resultado serían individuos "virtuosos" que pudieran realizar actividades mejor remuneradas, obtener mayores recursos y mejorar su calidad de vida por sí mismos. Es un ejemplo paradigmático de las transformaciones acontecidas en el marco del cambio de la sociedad fordista, basada en el bienestar, a la posfordista, caracterizada por la primacía de la "auto-ayuda", la ciudadanía, la beneficencia y la ayuda voluntaria, pero también por el auto-control y la auto-vigilancia.

Sin embargo, bajo la pretensión de estar dando un enfoque "integral" al problema de la pobreza, erradicando las supuestas condiciones que están en "la raíz" de ésta, los programas de desarrollo social y transferencias económicas como Progresa u Oportunidades no hacen sino evitar abordar la imperiosa necesidad de generar

4 Para un elocuente ejemplo de esto ver el discurso que el entonces presidente de México Ernesto Zedillo (1997) pronunció en 1997 durante la presentación del PROGRESA en una comunidad rural de Hidalgo. 
programas que incrementaran la oferta laboral y el monto de los ingresos, así como abatir la enorme desigualdad estructural que impera en el país (Favela et al 2003:40). Al mismo tiempo, al señalar que puede existir tal cosa como las "raíces de la pobreza", no se está haciendo más que naturalizarla, sugiriendo la idea de que si la miseria y la marginación persisten se deberá a que los pobres no han sabido aprovechar las condiciones de educación, nutrición y salud que se les han ofrecido para superar sus precarias condiciones de escolaridad, salud, nutrición y vivienda, dejando al fracaso como una cuestión de incapacidad personal y no como una cuestión de estructuras económicas y de poder que son increíblemente difíciles de romper y trascender.

En realidad, este tipo de programas fueron creados en el marco de la coyuntura planteada al comienzo de la década de los ochenta por la crisis económica y las políticas de ajuste estructural que generaron altas tasas de desempleo, y que llevaron al gobierno federal a implementar acciones concretas a nivel nacional que permitieran a los sectores más marginados de la población sobrevivir a esta situación. La política social se convirtió entonces no sólo en el mecanismo a través del cual esta meta sería alcanzada y el gobierno fundamentaría gran parte de su relación con los grupos sociales marginados, sino que constituyó también el medio por el cual se fueron moldeando sujetos sociales específicos y se fue construyendo una determinada concepción del "pobre" y la "pobreza" en México.

El discurso del desarrollo, escribe Arturo Escobar (1988:430-431), fue el resultado de la elaboración gradual y la combinación de una serie de elementos entre los que se cuentan la producción de nuevas formas de conocimiento y nuevas instituciones, la respuesta a los cambios acontecidos en la dinámica del capital, el reflejo de una nueva sensibilidad internacional hacia la pobreza y del éxito del Plan Marshall. Todos juntos, generaron una serie de elementos, instituciones, prácticas y relaciones sociales que aseguraran y perpetuaran su existencia junto con su profesionalización y la consiguiente creación de verdades y normas acerca del Tercer Mundo.

Una de estas verdades es la distinción establecida entre la pobreza extrema y la pobreza moderada mediante "criterios científicos" de medición y valoración introducidos por primera vez por el PRONASOL, y su consiguiente valoración y catalogación de los municipios como "marginados" o "altamente marginados". Siendo así, los programas de desarrollo social sentaron las bases para la institucionalización de 
la pobreza y el ejercicio del poder basado en las carencias y las necesidades de los pobres. Surgía entonces un nuevo tipo de gubernamentalidad que comprendía no sólo la prescripción de políticas vinculadas con el desarrollo económico, sino la creación de una serie de instituciones destinadas a producir, racionalizar y controlar a los individuos a través de medios discursivos y materiales basadas en sus carencias y necesidades.

Al mismo tiempo, con la consolidación de los "estudios sobre el desarrollo" en las universidades más prestigiosas del mundo y la recién creada "economía del subdesarrollo", se descubría que el Tercer Mundo no podía confiar en el ahorro para impulsar su crecimiento porque éste era prácticamente inexistente, mientras que los beneficios del capital podrían ser copiosos en la privilegiada arena de la industrialización. Ésta sería además la mejor manera de conducir a las enormes masas de población excedente a actividades más productivas, en vez de dejarlas malgastarse en el campo, bajo condiciones productivas terriblemente ineficientes. A partir de ese momento la industrialización se convirtió en la clave para el desarrollo (Escobar 1988:431-433).

La proletarización del campesinado constituía una condición si no total, al menos parcialmente necesaria para el funcionamiento del patrón de desarrollo capitalista establecido durante la posguerra. De este modo se podría obtener, por una parte, mano de obra barata y poco calificada y, por la otra, a través de las cadenas globales de producción de alimentos, comida barata para alimentar al creciente proletariado. Esto puede de hecho ser considerado, señala Ong (1991:282), uno de los principios claves de la nueva división internacional del trabajo comandada por las compañías transnacionales.

Siendo así, durante los 80's se inició una incorporación más acentuada de México a la globalización mundial a través del modelo neoliberal y con enormes repercusiones para la dinámica de los sectores rurales y urbanos (Aragonés 2004:239). En el caso del campo en particular, este modelo económico que colocó al sector agrícola mexicano en directa competencia con las grandes potencias productoras en el mercado global no hizo sino provocar, como señala Aragonés (2004), un enorme deterioro social y económico que ha profundizado la miseria, la desnutrición y la dependencia alimentaria de nuestro país respecto a los Estados Unidos, además de provocar un incremento vertiginoso en la migración. 
Otra de las principales consecuencias de la aplicación de las políticas neoliberales en el sector agrícola, que ha privilegiado la competitividad y la maximización de las ganancias a través de una lógica empresarial y la exportación de cultivos no tradicionales, ha sido una enorme desregulación de los mercados rurales, deteriorando gravemente los mecanismos de reproducción económica de los campesinos mexicanos (Sánchez 2001:81).

En este contexto, ciertos aspectos de la política social en México como las transferencias económicas condicionadas, ampliamente difundidas en el sector rural, han sido un coadyuvante particularmente efectivo en tanto que, sin mejorar sustancialmente las condiciones de vida de la población campesina en las zonas rurales más marginadas, han contribuido enormemente a la introducción de valores y necesidades antes ajenas, basados fundamentalmente en concepciones urbanas del bienestar y enmarcándose a la vez "en una estrategia de crecimiento económico de bajo perfil que ha sido acompañada por altos niveles de subempleo e informalidad" (Favela et al. 2003:49).

A esto se debe añadir que la eficacia de programas como el Progresa ha sido limitada en tanto que "sus objetivos de proporcionar educación básica, salud y alimentación no parecen, por sí solos, suficientes para garantizar que sus beneficiarios obtengan en el mediano plazo una nueva y mejor ubicación en la sociedad, aunque sus acciones están diseñadas para generar condiciones que den nuevas habilitaciones entre la población objetivo", además de que "quienes fueron beneficiados por el programa no pudieron encontrar trabajo en el campo donde residen porque invertir en él no es una prioridad federal" y porque a las regiones indígenas se les ha mantenido completamente fuera del desarrollo del mercado (Favela et al. 2003:49-50).

Es evidente entonces, como bien mencionan Favela et al. (2003:50), que la interacción entre la política económica y el Progresa ha contribuido en gran medida a cerrar las posibilidades para que los campesinos beneficiaros de este programa sigan viviendo en el campo y abre una sola posibilidad: la migración al exterior o hacia centros urbanos o complejos agrícolas industrializados en el occidente y norte del país, donde el empleo no sólo es escaso y precario, sino explotador.

Tenemos entonces que el capital que se ha establecido en los países "periféricos" requiere del suministro permanente de trabajo y comida barata, y ha sido 
precisamente el discurso sobre el desarrollo el que le ha conferido al campesinado un rol especial en el cumplimiento de estas condiciones a través de una serie de estrategias y programas producidos para lidiar con estas necesidades (Escobar 1988:436). Un aspecto particularmente importante en este sentido ha sido la producción de conceptos como "trabajador migrante", "jornalero agrícola", "indígena pobre" y "campesino iletrado", así como la dotación a categorías preexistentes de nuevas y muy particulares características que se insertan muy bien en el discurso de la productividad y el buen desempeño del capitalismo, como cuando se asocia a una etnia en particular, o a las mujeres y a los niños con la habilidad de realizar un trabajo especializado mejor que otros grupos de trabajadores.

Parafraseando a Arturo Escobar (1988:435-437), podemos decir que este tipo de acciones no sólo generan un campo fértil para la implementación de programas especializados en tratar con este tipo de sujetos, sino que estructuran las relaciones que mantendrá con sus "clientes", de manera que la realidad local del campesino, el "pobre" o el "subdesarrollado" es organizada, trascendida y re-elaborada a través de las categorías creadas dentro del discurso institucionalizado de las políticas sociales. El resultado inevitable es la producción de un sujeto caracterizado por un comportamiento dado y constreñido por ciertas prácticas, o bien de un sujeto que es la representación de un problema susceptible de ser "combatido" o "erradicado" a través de un desarrollo efectivo. Todo esto desde luego se traduce en operaciones burocráticas, programas estratégicos y planes de acción que conforman un auténtico cuerpo de "técnicas de poder y conocimiento" que son concebidas desde entidades financieras internacionales que, la mayoría de las veces, poco o nada toman en cuenta la cultura, los conocimientos y las capacidades de los indígenas o los campesinos en cuyas vidas interfieren.

Ahora bien, todo lo anterior no tendría sentido si no estuviera fundamentado en una construcción particular de ciertas necesidades, un elemento fundamental para la legitimación del discurso político y el control social en el capitalismo tardío, y un terreno sumamente fértil para la elaboración y la perpetuación simbólica y material de las inequidades, como argumenta Fraser (1989).

Esto es particularmente interesante en tanto que, como indicara Ivan Illich (1990), en el discurso del desarrollo la existencia de las necesidades es legitimada y precisada 
por profesionales y criterios "científicos" que definen al sujeto por aquello que carece y no por aquello que posee. El cuadro se completa si consideramos que el nuevo conjunto de necesidades identificadas por el proyecto desarrollista están destinadas a ser cubiertas principalmente mediante una mayor producción y un mayor consumo de bienes y servicios.

La pobreza se volvió así un "concepto operacional", un problema que puede ser "resuelto" o un mal que puede ser "curado". El discurso de las necesidades adquirió además poder político en tanto que permitió establecer normas mínimas de "decencia humana" y modos de vida que "degradan" la vida de las personas, que pronto comenzaron a ser traducidos a cantidades en dólares por los científicos sociales que trabajaban para McNamara en el Banco Mundial. El "pobre" comenzó entonces a ser definido como aquél que carece de ingresos con los cuales satisfacer sus necesidades, y la "pobreza" se volvió un parámetro abstracto y universal para medir el subconsumo (Illich 1990) y que pronto comenzó a moldear nuestra concepción de la realidad.

En el comienzo de la década de los 50's mientras que el problema de los países en vías de desarrollo había sido entendido esencialmente como un problema de producción de riqueza, para el final de esta década era ya ampliamente aceptado que el factor crucial no era la producción, sino la capacidad para producir, que es inherente a las personas. Fue así como se volvió legítimo hablar de éstas como un ingrediente más del crecimiento económico y, por tanto, se volvió justificable hablar de aquellas personas o sectores de la sociedad que representaban un "freno" o un "impedimento" para el desarrollo, o bien que podían emplearse para "impulsar" el desarrollo de una nación o región (Illich 1990).

Es por esto que Fraser (1989) aboga por ciencias sociales que se ocupen más por la política de los discursos y las interpretaciones de las necesidades que por los mecanismos mediante los cuáles éstas son satisfechas, con el fin de hacer visible su carácter contextual y refutable, así como para entender mejor los intereses perseguidos por quienes las definen e interpretan; y cómo esto representa un área de contienda donde grupos con recursos discursivos desiguales compiten para establecer como hegemónica sus respectivas interpretaciones. Sólo así podremos comprender y mostrar que las necesidades de la gente no son algo dado y no-problemático, y que detrás de 
éstas hay toda una serie de poderes y relaciones sociales en juego que también se articulan con los patrones sociales de dominación y subordinación.

El centro de la discusión es entonces, siguiendo a lllich (1984a:58), no cómo y dónde emplear más recursos, sino por qué éstos deben ser empleados en absoluto pero, como postula este autor: estamos siempre más tentados a apuntalar y justificar estructuras que a cuestionar su propósito y veracidad.

\section{Marginación trashumante: la migración y el trabajo infantil jornalero}

Hasta ahora hemos visto un panorama general de la conformación socio-histórica de La Montaña de Guerrero, región de procedencia de un gran número de niños jornaleros indígenas, así como de los procesos económicos y políticos globales y nacionales mediante los cuales los campesinos han sido construidos como sujetos "atrasados" y convertidos en objeto de políticas desarrollistas. A continuación se ofrece un análisis de la situación de vida y trabajo de los indígenas en los campos jornaleros y en el marco del desarrollo capitalista.

Aunque el tema del trabajo jornalero agrícola es sumamente complejo y existen diversos puntos de enfoque para abordarlo, en esta investigación me referiré principalmente a la cuestión del trabajo infantil jornalero no sólo porque de todos las materias que el tema del trabajo jornalero engloba, éste es una de las menos estudiadas, sino porque considero que a través del estudio de la participación infantil en las cadenas de producción agrícola podemos comprender algunos de los procesos más complejos de subjetivación, control y construcción del sujeto en el capitalismo tardío.

Es realmente sintomático que junto con el aumento de la migración jornalera al interior de México durante las últimas décadas, ésta haya experimentado una marcada tendencia a volverse familiar. Es decir que si antes migraban sólo los padres de familia o los hombres adultos, ahora lo hacen en creciente proporción familias campesinas enteras. Estos cambios nos hablan de una mayor pauperización de las condiciones de vida en el medio rural y de las consecuencias de la adopción de un modelo económico neoliberal, pero eso no es todo. La implementación de este tipo de medidas macroeconómicas está relacionada con una serie de cambios en la 
organización productiva de la agricultura empresarial en el marco de la acumulación flexible posfordista.

Entre éstos encontramos, por ejemplo, cambios en los patrones de cultivo y el requerimiento de mano de obra (Sánchez 2005:362) con características cada vez más específicas, la introducción y el uso de cultivos genéticamente modificados, el uso de cada vez mayores cantidades de agroquímicos y de nueva tecnología para la siembra, como invernaderos, hidroponía, etc., que requieren que los trabajadores realicen actividades cada vez más especializadas y "delicadas", como amarres, cortes y embalajes. Esto hace que la participación de niños y mujeres, por su baja estatura, su "delicadeza" o sus manos "ágiles", sea sumamente eficiente y rentable para las productoras agrícolas. Muchas veces son los niños quienes realizan toda una serie de actividades paralelas o previas a la pizca o la cosecha -como la limpieza, el deshierbe o el desbrote- que no suelen ser remuneradas y su participación no sólo es admitida sino apreciada, pues "los empleadores consideran que por su estatura y tamaño realizan ciertas actividades con mayor eficiencia que los jornaleros adultos" (Sánchez 2005:367, ver también Barrón 1999:257).

Kim Sánchez (2005:369) reporta incluso la aparición de nuevas estrategias productivas en las empresas hortícolas de Baja California que consiste en separar a los niños de sus familias para formar cuadrillas a cargo de un mayordomo que les asigna lugares y cuotas de trabajo especiales de acuerdo a las ventajas que su trabajo representa. Cabe señalar que el beneficio obtenido por el empleo de la mano de obra infantil ha llegado a ser de tal magnitud que hace algunos años, empresarios norteamericanos e internacionales denunciaron la competencia desigual de los productores mexicanos que utilizaban el trabajo infantil y a quienes amenazaron con negarse a comercializar sus productos (Sánchez 2005:37, Bey 2003:293). Podemos pensar entonces que a la clara división sexual y étnica que existe en el sector agroexportador se añade una nueva diferenciación basada en la edad y el tamaño físico.

La creciente incorporación de mano de obra femenina e infantil en los campos jornaleros y el aumento de la población indígena en los mercados agrícolas no es un acontecimiento fortuito. Esto nos revela la anexión de nuevos grupos sociales que constituyen sujetos ad hoc para una política laboral que supone la desvalorización del 
precio de la fuerza de trabajo (Lara 1991:109) mientras la producción se intensifica. Esta situación ha sido bien aprovechada por el sector empresarial en nuestro país, con el favor de políticas débiles y un Estado laxo incapaz de garantizar el cumplimiento de los derechos laborales por igual a todos sus ciudadanos.

Es importante hacer notar que además la participación laboral de los niños en los campos agrícolas muchas veces contribuye también a regular las fluctuaciones en el suministro de mano de obra, pues cuando la demanda decrece éstos son los primeros en ser despedidos, pero quedándose siempre a la mano para cuando se les vuelve a necesitar (Sánchez 2005:367).

Ahora bien, para poder comprender la magnitud del flujo migratorio de campesinos hacia los campos agrícolas de exportación es necesario conocer algunas cifras (citadas por Pérez Villalba 2005:386). Por ejemplo: para el 2005 la participación del sector agropecuario en el Producto Interno Bruto había disminuido del 7.8\% (en 1990) al $4.2 \%$. Además, a finales de los 90 's, uno de cada cuatro trabajadores en el país estaba ocupado en el campo y esto ha disminuido a menos de uno por cada cinco trabajadores. A esto se suma que México tiene la tasa más baja de subsidios para el campo con un promedio de 44 dólares por hectárea cultivada, según la OCDE (citado por Pérez Villalba 2005:386). El Banco Mundial y el Banco Interamericano de Desarrollo reconocen que el campo mexicano "agoniza", debido a que la población rural no recibe apoyo suficiente, no se ha desarrollado un mercado, ni colocado al desarrollo agrícola como un asunto de seguridad nacional.

Pérez Villalba (2005:387) reporta que hay ocho millones de campesinos en el país, de los cuales un millón son mujeres y seis de cada diez son jornaleros, y que en el lustro de 1995 al 2000 más de dos millones de campesinos (28\% del total) abandonaron el campo. Por su parte, el Programa Nacional de Jornaleros Agrícolas (2000:31) reportaba en el 2000, basado en los datos de la Encuesta Nacional de Jornaleros Migrantes, que 3 de cada 7 niños y 3 de cada 8 niñas de entre seis y once años de edad se incorporan al trabajo asalariado fuera de su comunidad. Kim Sánchez (2005:362) señala que varios estudios coinciden en que la mayoría de estos niños que laboran como peones agrícolas se concentran en cultivos comerciales intensivos de mano de obra y fuerte demanda de trabajo estacional y que además se caracteriza por la persistencia de una variedad de labores no mecanizadas, consideradas de escasa calificación y que 
por lo tanto son mal pagadas. En México estos cultivos suelen ser las hortalizas y los cultivos industriales de café, tabaco, caña de azúcar y algunos frutales de corte anual.

No obstante su importancia numérica y económica, no existe una dato certero de cuántos jornaleros agrícolas hay en México, las cifras suelen variar de acuerdo al organismo o institución que las presente. Según Alejandra Villalpando (2005:21), coordinadora del Programa de Atención a Jornaleros Agrícolas (PAJA) en Hidalgo éstas pueden alcanzar desde los 2.2 hasta los 6.5 millones de personas. Por otra parte, el PRONJAG (Programa Nacional de Jornaleros Agrícolas) calculaba en 1996 que había alrededor de 3.6 millones de jornaleros agrícolas migrantes en el país, de los cuales 1.2 millones corresponden a niños y niñas menores de 18 años, según informan el Poder Ejecutivo Federal y la SEP (1996:46), cifra que muy probablemente se ha incrementado desde entonces. Por su parte, la UNAM calculaba en el 2007 entre los 2.5 y los 3 millones el número de niños trabajadores en el país (Herrera y Ayala 2007:10), mas no ofrece cálculos sobre cuántos de ellos podrían estar empleados en el sector agrícola.

Es un hecho que debido a la heterogeneidad y la alta movilidad espacial que caracteriza a esta población, resulta sumamente difícil elaborar cálculos precisos sobre el volumen total de jornaleros agrícolas en México (Sánchez 2001:80). Sin embargo éste no es un argumento válido para justificar la carencia de políticas públicas capaces de abarcar y resolver, al menos de manera incipiente, las apremiantes carencias de esta población que conforma el principal motor de la economía agrícola de exportación en México. Habrá que determinar si esto se debe a una incapacidad o a una falta de voluntad política, o más bien a una intención de ajustar los mecanismos de reproducción económica de la población campesina del país a las necesidades y exigencias del capital transnacional y el mercado laboral agrícola de exportación.

Es interesante notar que desde la firma del Tratado de Libre Comercio con América del Norte, los productores mexicanos se han visto avasallados por las enormes capacidades productivas de las grandes transnacionales, pues basta solamente saber que tan sólo en el primer periodo desde la entrada en vigor del TLCAN la producción agrícola en México disminuyó un 50\%, mientras que las importaciones se incrementaron en un $73.23 \%$. Es imposible no reconocer los nocivos efectos que todo esto ha implicado para los productores campesinos mexicanos, de los cuales uno de cada seis ha tenido 
que abandonar sus tierras, tan solo como consecuencia de la importación mexicana de maíz estadounidense barato entre 1994 y 1998 (Aragonés 2004:247-48).

Pero peor aún, al poner a competir a la agricultura mexicana minifundista y de temporal con las grandes productoras internacionales y hacer de la agricultura "moderna" una actividad donde las necesidades de inversión y tecnificación sólo pueden ser cubiertas por dueños de empresas agrícolas o capitales transnacionales, los pequeños productores y los campesinos indígenas han quedado automáticamente excluidos de los beneficios que supuestamente el TLCAN representaría para el "desarrollo rural". Como consecuencia a esto, la migración jornalera se ha convertido muchas veces en la única vía de supervivencia para millones de familias campesinas, indígenas y rurales del país.

Todavía más desconcertante resulta saber que, a pesar de que con la firma del TLCAN el sector rural mexicano se enfrentaba a una competencia sumamente injusta, el gobierno federal tomó medias para reducir el monto del capital asignado para apoyar al campo. Su inversión en proyectos agrícolas cayó un $90 \%$ en siete años, siendo que el $39 \%$ de la población nacional vive en comunidades rurales (Aragonés 2004:258). A la par de esto, el auge de los cultivos hortofrutícolas y en general de los cultivos no tradicionales orientados a la exportación, principalmente en el noroeste del país, ha sido enorme, y ha constituido uno de los factores más decisivos en la masificación de los flujos de migración laboral interna con destino rural y desde las regiones deprimidas del sur de México (Sánchez 2005:363).

Ahora bien, para poder comprender a cabalidad la cuestión del trabajo infantil, es necesario entender primero la naturaleza del trabajo familiar indígena-jornalero y el uso que de él hacen las empresas productoras. Probablemente la característica más importante y aprovechable de la migración indígena a los campos jornaleros es que la gran mayoría de las veces emigra la familia entera, y ésta suele incorporarse a la producción agrícola como una "unidad productiva jornalera" (Sánchez 2005:369).

Las ventajas de esta estrategia adoptada por la unidad doméstica indígena para adaptarse a la especialización del trabajo, incrementar su producción y maximizar los bajos ingresos, son enormes para la empresa agrícola. En primer lugar ésta resulta beneficiada por la organización y jerarquización ya establecida al interior de la familia pues, como postula Sánchez (2005:369) aquí el jefe de familia es el responsable 
de capacitar a sus hijos, distribuir el trabajo, apoyar a los novatos o rezagados y asegurar que el trabajo se realice adecuadamente. Al mismo tiempo el pago a destajo, usado frecuentemente por las empresas agrícolas, alienta a la vez que garantiza la productividad y la intensificación del trabajo familiar e infantil, dado que será del interés de los jornaleros incrementar los magros ingresos incorporando a más miembros.

En este contexto, el uso de la fuerza de trabajo de los niños llega incluso a volverse fundamental para la reproducción productiva y económica de la familia, pero al ser visto como una "prolongación" del trabajo realizado por los adultos, tanto por los propios padres como por los patrones, se oculta e invisibiliza la explotación a la que éstos están siendo sometidos. A esto contribuye la tendencia nada infrecuente de calificar su trabajo como "ayuda" y a equiparar las labores que los niños realizan junto con sus padres en los surcos con las actividades que llevan a cabo en sus comunidades durante el ciclo agrícola, justificando su trabajo jornalero como "parte de los valores tradicionales de sus familias". Ahora bien, este "doble sentido y función" otorgado por familias y empresas al trabajo infantil "refleja la relación contradictoria y subordinada de las regiones de la agricultura de subsistencia a la agricultura comercial" donde el trabajo infantil aparece como "un imperativo refuncionalizado desde la lógica empresarial que aprovecha al máximo las (des)ventajas de la fuerza de trabajo eventual" (Sánchez 2005:369-371).

Finalmente, la presencia de los niños -y de las niñas principalmente- en los campos jornaleros resulta fundamental aún cuando no se encuentren trabajando con sus padres en los surcos, puesto que mientras la familia pasa todo el día fuera, las niñas se encargan de preparar la comida, moler el maíz y cuidar a los hermanitos más pequeños. Esto se convierte en un provechoso medio adicional para reducir el costo de la reproducción de la mano de obra que los empresarios aprovechan para reducir sus gastos y, como señala Sánchez (2005:371), para aprovechar por más tiempo a los trabajadores a los que los niños han librado de realizar estas tareas. Tenemos entonces que "una parte fundamental del costo de la reproducción cotidiana de los trabajadores que debería cubrir el empleador" es transferida a los niños y vista como algo natural. 
Con esta normalización de la participación y el trabajo infantil, inestable y no especializado, no sólo se consigue mantener bajos los salarios, sino que es una manera muy efectiva de ir creando trabajadores dóciles, acostumbrados a ser considerados desechables y a no poseer ningún derecho laboral ni garantías de otro tipo. 
Capítulo 2

\title{
El sujeto y el tiempo en el capitalismo tardío
}

\begin{abstract}
We have a dream: a World free of poverty
(Inscripción en la sede del Banco Mundial en Washington)

...and thanks to the World Bank, it remains a dream.

(Polet \& Houtard 1999)
\end{abstract}

\section{Cadenas globales de producción}

Hablar del trabajo jornalero y la producción agrícola de exportación requiere forzosamente hablar de las cadenas globales de mercancía, lo que a su vez nos remite al tema de la transformación de la producción capitalista y el mercado de trabajo en el régimen de acumulación flexible. Pero sería difícil comprender adecuadamente estos fenómenos sin tratar además el de la modernidad. En este capítulo intentaré trazar algunas de las conexiones entre estos temas y la transformación del trabajo y la migración jornalera en México.

Nuevamente, y retomando el enfoque propuesto por Goodman y Redclift (1991:xii), se propone un análisis en base no a las causalidades históricas, sino en el desarrollo de transformaciones y procesos interconectados local y globalmente. Se parte de la idea de que el sistema moderno de producción agrícola es reflejo de una reestructuración y una nueva construcción de los ámbitos social y económico; y que su desarrollo ha implicado una creciente separación entre las formas de producción y las estrategias de subsistencia campesina, favoreciendo la creación de una fuerza de trabajo flexible, precaria y móvil que pueda ser aprovechada y desechada a conveniencia, maximizando las ganancias del capital global.

Es un hecho que la agricultura campesina y el modo de vida rural basado en la autosubsistencia alimentaria actualmente es prácticamente una utopía debido a dos grandes factores que se retroalimentan: por una parte a la devastadora influencia de las cheap food policies o "políticas de alimentos baratos" que han agravado la pobreza rural y han orientado el consumo urbano hacia los granos importados, las 
proteínas animales y los productos procesados; y por otra, a la pérdida de la autonomía alimentaria de la mayoría de los países del "Tercer Mundo", que a su vez responde a la nueva división internacional del trabajo que incrementa la importancia estratégica de la agricultura de exportación, desplazando aún más a los cultivos domésticos y a sus productores rurales (Goodman y Redclift 1991:xv-xvi).

Esto se vincula además con toda una serie de cambios culturales y políticas públicas que han influido enormemente en la transformación de los campesinos, de productores autosustentables a sujetos precarios con múltiples y nuevas necesidades insatisfechas: consumidores de todos los productos y elementos -materiales y simbólicos- que son parte del modo de vida urbano, occidental y por tanto, no-pobre y no-indígena. Sucede entonces que las transformaciones económicas, tecnológicas y políticas que han sustentado el desarrollo moderno de la agricultura de exportación además de provocar un cambio en las formas de trabajo agrícola, están provocando también -y a gran velocidad- cambios en el comportamiento y la auto-percepción de quienes constituyen su nuevo ejército laboral. Pero, ¿̇se trata de un cambio que propone nuevas alternativas a los antiguos mecanismos de subordinación o por el contrario contribuye a fortalecerlos y perpetuarlos? ¿Son los jornaleros migrantes un sujeto con nuevas posibilidades de agencia y resistencia o son sólo la expresión de una nueva modalidad de antiguas formas de explotación?

Para responder a estas preguntas será de gran utilidad estudiar las formas en que las familias campesinas e indígenas jornaleras se adaptan y contienden con las transformaciones tecnológicas y las nuevas exigencias de la producción agrícola de exportación, influyendo a su vez en la organización y el desarrollo del trabajo agrícola. Pero debe hacerse entendiéndolas no como meras unidades productivas, sino como un grupo de personas interdependientes donde las relaciones generacionales y de género, así como las diferencias en los roles son cuestiones trascendentales para entender sus funciones económicas y productivas. Esto nos permitirá entender si la familia campesina migrante se transforma, se disuelve en relaciones laborales, o si se fortalece al emplearse como una unidad productiva en el trabajo agrícola jornalero.

Retomando algunos postulados de Goodman y Redclift (1991:75), podemos trazar una comparación entre lo que estos autores señalan para el desarrollo del trabajo

\footnotetext{
${ }^{5}$ Aragonés (2004) presenta un buen panorama del desarrollo de esta industria y su relación con México.
} 
femenino en el contexto de la producción agrícola familiar con el trabajo infantil en los campos jornaleros. Así, es posible postular que mientras la especialización de las tareas agrícolas crece, la carga de trabajo pasa de la fuerza de trabajo asalariada a los niños, por su capacidad de asumir algunas de las tareas y responsabilidades de los adultos, como el cuidado de los niños pequeños, la compra y la preparación de alimentos, el aseo de la vivienda, etc. De este modo, los miembros de la familia se vuelven cada vez más dependientes de la presencia y la ayuda de los niños como una estrategia de complementación de las funciones entre los miembros de la familia. Es precisamente en este contexto que el trabajo de los niños se vuelve adaptable a las necesidades de los adultos y pierde valor, en tanto que es una función más de la unidad productiva familiar quedando, por lo tanto, invisibilizado.

Durante la industrialización y la expansión del capitalismo que caracterizó al fordismo, la agricultura jugó un rol fundamental, en tanto que permitió disminuir la presión sobre la tasa de beneficio suministrando productos alimenticios básicos a precios verdaderamente bajos para el sector urbano e industrial (Goodman y Redclift 1991:87). Pero ahora, en la era de la acumulación flexible posfordista, la precarización de la agricultura y la creación de nuevos patrones de desarrollo mediante las "políticas de alimentos baratos" y la casi eliminación de la auto-subsistencia alimentaria de los campesinos, parece estar destinada no sólo a atraerlos hacia un nuevo mercado laboral migratorio y temporal, sino al creciente mercado de consumo de servicios y mercancías de producción masiva.

Uno de los aspectos más interesantes a estudiar no es cómo el capitalismo produce una separación entre la fuerza de trabajo y los medios de producción, como se mencionaba antes, sino cómo las muy particulares características de la industrialización posfordista y el régimen de acumulación flexible producen una desestructuración y una transformación en el modo en que el tiempo y el espacio son concebidos y producidos en el contexto de la destrucción de formas tradicionales de vida, el surgimiento de nuevos sujetos que responden a las necesidades del mercado de trabajo y de posibilidades tecnológicas, comunicativas y de desplazamiento inéditas.

Un efecto de estos cambios en la concepción y el uso espacio-temporal es la moderna interconexión de zonas productivas geográficamente discontinuas mediante 
un patrón de producción que incorpora nuevas tecnologías agrícolas (modificación genética de semillas, invernaderos, fertilizantes, etc.) que le permiten al capital romper la dependencia de las estaciones del año y asemejar el proceso de producción agrícola al de la industria y volverlo su complemento (Goodman y Redclift 1991:96,100). Aunque la más sólida y potente relación entre la agricultura y el modelo de producción fordista se dio en el ámbito de la producción y manufactura de comida, ésta continuaba resistiéndose a la adopción de los principios fordistas de organización para regir y racionalizar su capacidad productiva, dejándole al estado la tarea de resolver las contradicciones inherentes (Goodman y Redclift 1991:100-102). No obstante, con la transición al modo de acumulación flexible, la agricultura ha podido ser transformada para ser incorporada coda vez con mayor efectividad a las características de la producción industrial y posfordista.

Junto con las políticas y los tratados de liberalización del mercado (como el TLCAN y el GATT), la prioridad otorgada a los cultivos de exportación y la casi desaparición de los apoyos gubernamentales a los pequeños productores, los factores que más han contribuido a transformar el rostro de la agricultura en México han sido: una creciente tecnificación de las técnicas productivas, la manipulación genética de las semillas para crear cultivos más resistentes, mejor adaptados y con mayor capacidad de respuesta a los agroquímicos, el desarrollo de cadenas de frigoríficos que permitan almacenar los productos y mantenerlos frescos, así como los cambios y la internacionalización en los patrones urbanos de preparación y consumo de los alimentos.

A esto se debe añadir la pérdida de la soberanía alimentaria de los países del Tercer Mundo a partir de la puesta en marcha de diversas estrategias geo-políticas de "ayuda alimentaria" promovidas por los Estados Unidos en su plan Marshall de desarrollo durante la posguerra -y con el apoyo del BM, el FMl y el BIRD (Banco Internacional para la Reconstrucción y el Desarrollo)-, que creó la dependencia de granos importados, transformando a los antiguos beneficiarios en consumidores, y mermando el consumo de productos locales (Goodman y Redclift 1991:134-139).

Esto ha provocado en gran parte de América Latina -y México no es la excepción- un déficit en los productos agrícolas de consumo doméstico y bajas tasas de productividad, crecimiento e innovación de los productos alimenticios básicos, y 
que las prácticas productivas riesgosas e ineficientes se vuelvan el escenario cotidiano de los campesinos pobres, descapitalizados e indígenas (Goodman y Redclift 1991:141). Desde luego, esto ha contribuido a incrementar la migración campesina a los complejos agrícolas empresariales.

La importancia de un enfoque en las cadenas globales de producción radica entonces en que nos permite ver la serie de procesos globales sociales, económicos y políticos que interconectan incluso a las regiones campesinas más remotas con el capital transnacional, permitiéndonos tener una visión más amplia y compleja de las influencias, las transformaciones y las vías de acción. De igual manera, este enfoque nos posibilita para entender el impacto que un cambio en las pautas de consumo -ya sea por una moda o como consecuencia de la pérdida de la autonomía alimentariaejerce sobre la creación de nuevas mercados laborales, y todos los cambios socioculturales que esto acarrea para los sujetos y las colectividades.

\section{Control y disciplinamiento en el capitalismo tardío}

Hemos visto hasta ahora cómo la transición a un modelo posfordista de producción agrícola ha generado una mayor tendencia a la liberalización de los mercados, a la dependencia de cultivos de exportación, a la des-regulación y a la casi exterminación de los modos tradicionales de producción campesina-rural. Según los estudios sobre la migración y el trabajo jornalero en México, esto ha implicado para los trabajadores estacionales nuevas modalidades de ocupación del espacio rural basadas en una "multipolaridad" de los desplazamientos migratorios, pues las nuevas alternativas productivas son la des-estacionalización de la producción y la dispersión geográfica de las empresas agrícolas en amplias zonas ubicadas al norte del país, que crean "configuraciones familiares" ad hoc para los desplazamientos temporales (Lara 2008:18-19). Estas nuevas alternativas productivas han requerido y propiciado el surgimiento de patrones de migración que han sido denominados como de "justo a tiempo" (Besserer y Gil 2008:82), que permiten a las empresas disponer en el momento preciso de la cantidad necesaria de trabajadores temporales que pueden ser despedidos y re-contratados según las necesidades y la conveniencia del capital. 
Un ámbito en lo que esto se hace más evidente en México es el de la producción hortícola que, a pesar de no ocupar una superficie muy extensa (8 ó 9\% de la superficie agrícola total), su importancia se advierte en el hecho de que aporta entre un 34 y un 37\% del valor de la producción agrícola nacional (Grammont et al. 1999:xii). En 1999 nuestro país se había convertido en el octavo exportador mundial de frutas y hortalizas con una participación de $4.52 \%$ en el total de las exportaciones mundiales, generando el 22.6\% del empleo rural (Rubio 2004:39,42). Pero a pesar de esta importancia, y en contraste con otro tipo de cultivos, en este sector nunca ha habido un control de los precios de venta ni una intervención directa del estado en su comercialización (Echánove 2004:207).

El creciente proceso de industrialización que la agricultura en México ha venido experimentando durante las últimas dos décadas ha sido todavía más acelerado en el caso de las hortalizas, donde la creciente incorporación de insumos agroquímicos, maquinaria agrícola y paquetes tecnológicos evidencia el control que sobre este ramo ejercen las industrias alimentarias, pues son las únicas que cuentan con el capital suficiente para la implementación de los insumos. Las agro-industrias transnacionales y los países desarrollados, que otorgan cuantiosas subvenciones a sus productores, son mayormente quienes detentan el poder de decidir sobre el rumbo del sector agropecuario de nuestro país y de muchas otras regiones del mundo (Echánove 2004:208), hasta el punto de convertirse en integradores $u$ ordenadores de la actividad primaria (CEPAL-FAO 1998:31), y ejerciendo una suerte de "colonialismo alimentario" (Rubio 2004:22).

El sector de las hortalizas se caracteriza además por ser el más moderno de toda la agricultura mexicana, por su uso intensivo y especializado de la fuerza de trabajo y por constituir un escenario donde puede apreciarse el surgimiento de una "nueva ruralidad". Otra característica importante es que aquí se administra con mayor eficiencia el uso y el rendimiento de la fuerza laboral para mantener la misma calidad en los productos y disminuir el valor relativo del costo de producción a pesar del incremento de la carga de trabajo (Grammont 1999:3,13).

Pero la horticultura de exportación puede ser pensada como una expresión más de la flexibilización posfordista porque no sólo implica el desarrollo de nuevas tecnologías, un nuevo énfasis productivo sobre el consumo y los gustos de los 
consumidores, la feminización de la fuerza de trabajo o su integración a los mercados globales. La agricultura de exportación es típicamente posfordista porque conlleva además un nuevo régimen social y político de control y disciplinamiento de los sujetos.

Ya el fordismo había creado un modelo de regulación social generalizado y emblemático ajustado a las sociedades nacionales que organizaba a los individuos disponiendo de sus cuerpos en el tiempo y el espacio, coordinando sus fuerzas, transmitiendo poder entre ellos y ordenando las relaciones sociales básicas de acuerdo a una lógica de control diseñada por expertos. El resultado de esto fue una gubernamentalidad totalizante, nacionalmente delimitada y dirigida a racionalizar todos los aspectos de la vida social más allá del ámbito productivo e introduciéndose en la vida familiar y comunitaria (Fraser 2003:19-20)

Una de las principales características de la disciplina fordista fue precisamente que estaba socialmente concentrada en un modelo nacional donde las instituciones de control social estaban interconectadas, trabajando primordialmente mediante la autorregulación, la automotivación y el autogobierno de los individuos. Su objetivo general era la subjetivación de los individuos para mantenerlos responsables de sus procesos internos y aumentar sus capacidades de auto-vigilancia, alentando su autonomía para controlarlos y convertirlos en agentes de control social. En el plano de la producción masiva de mercancías, el resultado fueron cuerpos útiles y dóciles al disciplinamiento de lo "nacional social" (Fraser 2003:21-25).

Sin embargo en la era actual de la globalización posfordista, "Ias interacciones sociales trascienden cada vez más los límites de los Estados", el ordenamiento de las relaciones sociales se ha desnacionalizado o transnacionalizado al tiempo que sus mecanismos regulatorios se van articulando con los ubicados en otros niveles para crear un "nuevo tipo de estructura regulatoria, un sistema de múltiples capas de gubernamentalidad globalizada", más privatizado, disgregado, múltiple, disperso y sujeto al mercado; y en el que la autorregulación ahora se mezcla con la represión (Fraser 2003:24-27). Con el posmodernismo, la fragmentación del sujeto ha venido a reemplazar a la alienación, al tiempo que la vieja concepción del sujeto centrado se derrumba (Jameson 2001:35-36).

La nueva gubernamentalidad posfordista, nos dice Fraser (2003), actúa en un espacio disgregado de múltiples niveles que tienen funciones distintas, y en el Estado- 
Nación no es sino uno más de esos niveles; actúa y gobierna a distancia mediante redes flexibles y fluctuantes que trascienden a lo institucional y lo estructurado. El orden social, por lo tanto, "trabaja por medio de poderes y voluntades de una colección dispersa de entidades que incluyen Estados, organismos supranacionales, compañías transnacionales, ONG's, asociaciones e individuos [...] El resultado es un aparato de reglas cuya composición es tan compleja y cambiante que escapa a una descripción y comprensión única y fija". Esta gubernamentalidad posfordista descansa mucho más en los mecanismos del mercado y en el molde del neoliberalismo, que permite expandir el alcance de la racionalidad económica al introducir la competencia en los servicios sociales, transformando a los clientes en consumidores y sometiendo a los profesionistas a la disciplina de mercado. En esta "gubernamentalidad desestatalizada", la política de bienestar cede lugar a las tecnologías formales de responsabilidad económica, redefiniendo a los individuos para que asuman nuevos niveles de "responsabilidad" en sus vidas y dejando que el mercado organice grandes segmentos de la actividad humana. (Fraser 2003:27-30).

El resultado es un nuevo modelo de sometimiento que no descansa ya en la normatividad individualizante ni en el dominio del bienestar colectivo, sino en el de la gubernamentalidad. Ahora, dado que el individuo ha sido convertido en sujeto de opciones de mercado y consumidor de servicios, está obligado a ampliar su calidad de vida por sí mismo y mediante sus propias decisiones, manejando su propio capital humano para maximizar sus beneficios. En la gubernamentalidad posfordista se encauza a los individuos en nombre de la eficiencia y la previsión del riesgo, se separa al capaz y competitivo del incapaz y no competitivo, construyendo cursos de vida distintos para cada uno. El resultado es una nueva clase de gubernamentalidad segmentada de autorregulación que construye una "sociedad dual" donde una zona completamente interconectada e hipercompetitiva coexiste con un sector marginal de excluidos sin aspiraciones (Fraser 2003:30). Buena parte de esto es visible hoy en los discursos puestos en marcha por las políticas públicas basadas en el asistencialismo y la beneficencia, donde se busca individuos dóciles pero virtuosos, capaces de enfrentar las adversidades de un mundo globalizado y una economía precaria con sus escasos recursos y por sus propios medios. 
El control y el disciplinamiento posfordista actúan gracias a la coexistencia de una serie de aparatos y dispositivos de poder y de subjetivación que producen y regulan las costumbres, los hábitos y las prácticas sociales. Los individuos son producidos y fabricados por las tecnologías del poder, que dirigen sus conductas mediante la imposición de métodos de control que encauzan, rechazan y expulsan (Giraldo 2006:108-1 10). En esta era del control y la disciplina capitalista, el "nuevo paradigma del poder es el cuerpo", a través de cuyo control y disciplinamiento se producen nuevas individualidades, pues "el poder es un control que se extiende por las profundidades de las conciencias y los cuerpos [...] y al mismo tiempo a través de la totalidad de las relaciones sociales" (Giraldo 2006:117).

Esto es un proceso ampliamente observable en los campos agrícolas de explotación, donde cientos de familias jornaleras deben trabajar y vivir en condiciones ignominiosas durante largas temporadas al año solamente para poder subsistir. Además, el trabajo jornalero es un trabajo que produce un disciplinamiento muy específico del cuerpo. Comenzando la jornada antes del amanecer para trasladarse a los campos, los jornaleros pasan la mayor parte del día agachados, realizando movimientos repetitivos y especializados que son equiparables sólo a los que realizan quienes trabajan en las fábricas maquiladoras. Al igual que éstos, los jornaleros pasan los meses rodeados por un paisaje perfectamente ordenado y organizado, conformado por millones de surcos trazados a lo largo de miles de hectáreas que poco se diferencian de las interminables líneas de ensamblaje de las fábricas, pero con la diferencia que aquí las temperaturas muchas veces sobrepasan los 40 grados centígrados, generalmente sin una sola sombra para guarecerse del sol, pues los árboles son inexistentes debido a que podrían contaminar los cultivos. La falta de agua potable a la mano, la prisa con la que se trabaja y la continua exposición a plaguicidas, insectos y plantas urticantes requiere de un estricto disciplinamiento del cuerpo, con el fin de poder soportar las largas jornadas y no caer enfermo.

Las condiciones de vivienda pueden incluso ser peores que la disciplina de trabajo. Son abundantes las investigaciones y los reportajes donde se documentan las terribles condiciones de insalubridad, hacinamiento y carencia hasta de los servicios más elementales que las familias jornaleras deben soportar para poder hacerse de algunos ingresos. En este momento sin embargo no pretendo reproducirlas, pues basta 
con decir que estas condiciones en las que los jornaleros son obligados a vivir no hacen sino mostrar y reforzar la existencia de un mecanismo de precarización y vulneración de su trabajo, sus capacidades de reproducción social y sus propios cuerpos, que está conformado por las relaciones de subordinación y explotación a las que son sometidos, el racismo muchas veces mostrado hacia los indígenas, la subestimación de su trabajo reflejada en los bajos salarios y, la mayoría de las veces, la negación del trabajo infantil como un trabajo valioso y que debe ser remunerado.

Esto concuerda con las ideas expuestas por Raymond Williams (citado en Ong 1987:3) de que la dominación hegemónica no es sólo una cuestión del control de las ideas y las prácticas, sino de una "saturación de todo el proceso de vida", es decir que los significados y las prácticas dominantes buscan moldear la sustancia de las experiencias cotidianas al controlar y disciplinar las expectativas, los significados y las prácticas constitutivas del sentido de la realidad y de las relaciones sociales de los subalternos. Al igual que las maquiladoras asiáticas, las empresas y las corporaciones transnacionales que dirigen la producción agrícola donde se emplean los jornaleros operan no sólo para controlar abiertamente los cuerpos de los trabajadores, sino para controlar además las formas en que éstos se ven, se viven y se piensan a sí mismos (Ong 1987:4).

La disciplina capitalista opera a través de redes superpuestas de relaciones de poder tanto en el lugar de trabajo como en dominio público, regulando las prácticas diarias, las normas y las actitudes que legitiman las relaciones de desigualdad sobre las que se apoya el capitalismo (Ong 1991:286). Como cuando se decide que a un contingente de trabajadores se le puede pagar menos a pesar de sus años de experiencia, simplemente por ser indígena y/o analfabeta y, por lo tanto, no estar "debidamente" capacitado.

Al ser incorporados a un tipo de producción en serie y a las relaciones capitalistas de producción, los jornaleros, al igual que los campesinos Malayos con los que trabajó Ong (1987:7), experimentan profundas contradicciones en su forma de ver el trabajo y la vida. Lo importante aquí es identificar los mecanismos de control que la disciplina capitalista y el Estado ponen en marcha para legitimar y regular las relaciones de desigualdad, alentando una violencia simbólica donde la dominación por parte del 
capital queda justificada en base al discurso del desarrollo, el progreso y el proceso de modernización.

Tenemos entonces que con la creciente desestacionalización de los cultivos las empresas agrícolas han logrado romper su dependencia productiva de los ciclos anuales del clima, logrando cosechas durante todo el año a lo largo de una cadena geográfica de campos donde se han cultivado distintos productos hortofrutícolas en una suerte de "archipiélago de campos" (Besserer y Gil 2008:81-82) que interconectan regiones, mercados, capitales, países, productos y transacciones. Con esto se logra acelerar los ritmos del trabajo, pero se vuelve prácticamente imposible la planeación anual de la migración, con importantes consecuencias negativas para la capacidad de negociación de las condiciones de trabajo y de vivienda para los jornaleros agrícolas. Esto, desde luego implica para ellos nuevas condiciones de sometimiento, pues no sólo no pueden exigir mejores condiciones laborales porque no se sabe cuándo habrá trabajo, sino porque su vida personal y comunitaria muchas veces queda supeditada a la necesidad de migrar para subsistir.

Este moderno mecanismo de producción ha sido posible sólo gracias al desarrollo de cadenas frigoríficas que permiten mantener frescos y almacenados los productos antes de ser exportados, en lo que incluso llega a constituir "nuevas regiones fronterizas" entre países como México y los Estados Unidos (Besserer y Gil 2008:81). Nos encontramos entonces en un mundo que está siendo constantemente transformado por la fragmentación, la reconstrucción y la interconexión de acuerdo a las necesidades del capital global, y en el que los migrantes jornaleros son sujetos a la deriva, intentando incorporarse al panorama cambiante, cada vez más inestable y precario. En el régimen de la acumulación flexible las características -y las necesidadesimperantes del capital son la movilidad, la velocidad, la flexibilidad, el dinamismo, lo efímero y las ganancias a corto plazo. Los jornaleros agrícolas circulan en este nuevo espacio de producción posfordista adaptando, en la medida de lo posible, sus "calendarios de viaje y vida" para hacerlos compatibles, creando así la "migración justo a tiempo" (Besserer y Gil 2008:82) que permite a las empresas disponer en el momento preciso de sendos contingentes de trabajadores temporales que pueden ser despedidos y re-contratados según las necesidades y la conveniencia del capital. 
Como postulan Besserer y Gil (2008:82), con la aceleración de los ritmos de producción, transporte, distribución y de la tasa de retorno de las ganancias, encontramos también un aumento en la velocidad de los ritmos de vida, desplazamiento y trabajo de los jornaleros temporales que provoca la descarga de una "violencia por aceleración" que trae como consecuencia un proceso de dislocación y desarticulación que irrumpe en "los tiempos rituales, familiares, comunitarios, campesinos e incluso íntimos y corporales".

Otro poderoso "experimento", como lo llama Ong (1991:282), del nuevo orden internacional de la producción que ha contribuido a una todavía mayor flexibilización de los sujetos, ha sido la corporación y división de ésta en sistemas de subcontratación que han propiciado que el mercado del trabajo local quede supeditado a las demandas del capital transnacional. Ahora las manufacturas no están confinadas a ciertas zonas comerciales, sino que se dispersan por la geografía global gracias a la fragmentación del proceso productivo y a la capacidad de subcontratación de los empresarios locales. Este es justamente el régimen de producción al que están sujetos los jornaleros migrantes en México, donde el auge y la expansión de la producción hortícola ha influido directamente en la conformación de los mercados de trabajo rural, por ser cultivos que hacen un uso intensivo pero temporal e intermitente de la mano de obra (Sánchez 2006:147).

Esto ha hecho que la producción hortícola se caracterice por ser una "agricultura de contrato", es decir que se desarrolla a partir de acuerdos temporales, orales $O$ escritos entre firmas agroindustriales y productores (que pueden ser exportadores, procesadores, comerciantes o empacadores) con los cuales se especifica una o más condiciones de producción y comercialización de determinado producto (Roy 1972:3) y quienes a su vez se encargan de subcontratar a cuadrillas de trabajadores jornaleros. Por lo tanto, este tipo de producción se ha vuelto cada vez más lábil y flexible, en tanto que en ella confluyen numerosos agentes cuyo poder, intereses y necesidades son extremadamente disímiles. Estos agentes suelen ser:

- La industria agroalimentaria o empresa transnacional, que diseña un programa anual de siembras en función de los volúmenes de producto que necesita procesar y luego contrata a una serie de productores para abastecerse, determinando a priori la 
superficie que será cultivada, los requisitos de calidad que el producto habrá de cumplir y el precio al cual será pagado (Echánove 2004:228-29).

- El productor, que está obligado a seguir las instrucciones técnicas del personal capacitado de la empresa y a venderle toda su cosecha a ésta. Los productores pueden ser "financiados" o "no financiados", dependiendo de si reciben insumos como plántulas, pesticidas, fertilizantes, etc., cuyo costo les es descontado del precio total a pagar (Echánove 2004:229). Éstos, como ha mostrado Sánchez (2006:186), generalmente desconocen quiénes son los trabajadores jornaleros que trabajan en sus tierras produciendo lo que él vende, pues la selección y el reclutamiento están casi exclusivamente en manos de los intermediarios o enganchadores.

- Los intermediarios laborales, contratistas o enganchadores, que son quienes se encargan de reunir cuadrillas de jornaleros entre los trabajadores locales, o bien se trasladan a las comunidades campesinas e indígenas marginadas para reclutar grupos de familias que migran temporalmente al campo agrícola. Su función principal, señala Sánchez (2006:194) ha sido la de organizar "el mercado laboral para adecuar los requerimientos específicos de los productores comerciales a las características propias de la mano de obra disponible".

- Los campesinos minifundistas y/o indígenas que, por las condiciones socioeconómicas prevalentes en su lugar de origen y la crisis generalizada del campo mexicano se ven obligados a migrar, algunos temporal y otros permanentemente, a los campos agrícolas del norte del país para emplearse como jornaleros, muchos de ellos acompañados de toda su familia con el fin de maximizar las míseras ganancias.

Es posible decir que las relaciones de explotación a las que los jornaleros se someten se consolidan y tienen una particular expresión en su relación con el enganchador. Dado que los jornaleros nunca establecen acuerdos directamente con los productores y mucho menos con las empresas, el enganchador es el encargado de mediar entre estos actores. Sin embargo, su poder de negociación es prácticamente nulo, pues aún cuando pida mejores condiciones salariales y de vivienda, la gran mayoría de las veces esto no queda sentado en contrato alguno y sus garantías se basan en meros acuerdos verbales. Suele suceder que al arribar a los campos, los jornaleros se encuentran con condiciones mucho más precarias y sueldos más bajos de lo que les había sido prometido, pero en ese momento ya no hay marcha atrás. 
Es sustancial por consiguiente entender la importancia de la "economía moral" en las relaciones de explotación de los jornaleros migrantes, pues son este tipo de relaciones y acuerdos entre paisanos o conocidos las que posibilitan el flujo migratorio y las relaciones económicas. A éstas se añaden también las relaciones clientelares y de confianza que existen entre los trabajadores y los patrones o jefes de mayor estatus, en quienes ellos confían para resolver cualquier problema que pudiera surgir, esperando que éstos aseguren su bienestar en caso de dificultades mayores. Sobra decir que estas esperanzas la mayoría de las veces son defraudadas.

Resulta casi innecesario mencionar también que los campesinos que pueden convertirse en productores contratados directamente por las empresas son casi exclusivamente los grandes y medianos pues, además de que las empresas los prefieren sobre los pequeños agricultores porque reducen los "costos de transacción" (CEPALFAO 1998:54), éstos son los únicos que pueden cumplir con los requisitos exigidos, como: contar con una infraestructura básica (tractores, equipo de fumigación, medios de transporte para el producto, etc.), conocimientos en el ramo, solvencia económica para cubrir gastos de producción y gran disponibilidad de agua. De modo que aun si la industria hortofrutícola ha crecido en los últimos años, en realidad el número de productores que ha podido participar en ella se ha reducido, pues han sido eliminados todos aquellos que las empresas no consideran "fuertes" (Echánove 2004:230).

Este esquema de "agricultura por contrato" no sólo ha permitido a las agroindustrias controlar a su gusto el proceso de producción agrícola, imponiendo precios realmente ridículos cuando el producto no alcanza sus estándares de calidad (Echánove 2004:229), sino ejercer un dominio sobre la oferta, situarse en mejores condiciones para responder a las demandas cambiantes del mercado y los consumidores (USDA 1997:4), reducir los riesgos de la producción y tener mayor movilidad geográfica (Raynolds 1997:125). Todo ello, por supuesto, a costa de los productores nacionales y los trabajadores jornaleros.

A lo anterior debemos añadir que el capital global se beneficia aún más porque la subcontratación se realiza casi siempre en el Tercer Mundo, donde la legislación laboral suele ser mucho menos estricta que en los países industrializados y donde los patrones de trabajo suelen estar basados en las unidades familiares de producción que, como hemos visto, al incluir la participación de mujeres y niños, permiten la 
maximización de la fuerza laboral y el incremento de las ganancias. Todo esto suele ser completado por exenciones de impuestos, acuerdos comerciales favorables y ofertas de apoyo para la infraestructura por parte de los gobiernos locales. Pero además la subcontratación, uno de los pilares de la acumulación flexible, "reduce la visibilidad de las firmas transnacionales, permitiéndoles ignorar los costos políticos y económicos" (Ong 1991:283) e incluso ambientales que suelen ser consecuencia de sus patrones de explotación. Al mismo tiempo, permite aprovechar las diferentes ventajas que ofrecen los distintos espacios geográficos, amortiguar los costos de las fluctuaciones del mercado, proteger el capital de las grandes corporaciones y volver a estas últimas más flexibles ante la competencia y el riesgo (Harvey 2004:175,178).

Como muestra Ong (1991:284), la creciente preferencia de las corporaciones transnacionales por los sistemas "mixtos" de producción, ha creado una fuerza de trabajo heterogénea que ya no sólo incluye hombres sino también, y de manera creciente, mujeres, niños y trabajo importado. Por ende, ésta ya no puede ser definida o entendida solamente en términos del espacio, la edad o el sexo, pues los límites tradicionales entre grupos ocupacionales, sectoriales y nacionales se han hecho cada vez más borrosos.

A la par de esta regulación ejercida por el régimen capitalista encontramos al Estado moderno que, al promover y marginalizar determinadas normas, valores e identidades, intenta regular la vida social imponiendo prácticas y discursos. Este podría ser el caso de la escolarización y la castellanización para las familias campesinas e indígenas de México, como dos grandes narrativas que han alentado a miles de personas del medio rural a emigrar en busca de una supuesta mejoría en su calidad de vida y a aceptar condiciones laborales infames. Todo con tal de romper el vínculo de clase que los une a su condición étnica y que ha sido asociada con la pobreza, el atraso y la ignorancia. La gran mayoría de las veces, viendo los padres que esto no será posible para ellos, continúan luchando con todas sus fuerzas para que ésta sea una realidad para sus hijos. Para que ellos puedan dejar de ser jornaleros, campesinos 0 indígenas, y se conviertan en profesionistas o, al menos, en maestros.

Es importante entonces estudiar las formas en las que el discurso capitalista, presente en las formas de explotación laboral, se complementa con el discurso normativo del Estado para instaurar jerarquías, relaciones de poder y definiciones 
hegemónicas de los trabajadores. Esto podría mostrarnos en algunos casos que muchas veces las relaciones laborales se articulan con las instituciones nacionales y las normas estatales destinadas a "elaborar y reinventar los principios de la superioridad racial y/o masculina" (Ong 1991:289). Un ejemplo es la infantilización de los trabajadores que, como resultado de su condición de subalternidad, deben obedecer y acatar órdenes de sus superiores sin posibilidad de objetarlas o contrariarlas. Otro ejemplo sería el documentado por Goldman (1999) en la industria frutícola chilena, donde el discurso del "control de calidad" se inserta en las relaciones entre gerente y trabajadores proporcionando mecanismos para calificar y disciplinar a los trabajadores, justificando su sujeción a condiciones físicas extremas que asegurasen la calidad de la fruta, al tiempo que se establece un vínculo entre la fruta exportada y la gente, el clima y el suelo chileno.

Por el hecho de ser considerados como los que realizan las tareas más "sencillas", aunque en realidad sean las más pesadas en términos físicos, y por ser los menos calificados de todos los trabajadores que participan en el proceso de la producción agrícola -por ser indígenas y/o no estar escolarizados- se justifica que los jornaleros sean quienes reciban los sueldos más bajos, aún cuando muchas veces son apreciados por su experiencia, su habilidad y su calidad en el manejo de los cultivos. Esta forma de dominación basada en el género, la raza o la escolaridad contribuye, nos dice Ong (1991:289), a hacer del "manejo científico" un aparato formidable para extraer el excedente de ganancias, que es la esencia de la producción fordista.

Este "manejo científico" o Taylorismo se basa en técnicas de fragmentación y dirección del tiempo, que le dicen al trabajador exactamente cómo debe ser realizada cada una de sus tareas y así poder obtener el más alto nivel de productividad dentro de una estricta economía del tiempo. La fragmentación de las habilidades de los trabajadores en simples procedimientos casi mecánicos, y la extirpación del juicio individual con la separación de la concepción y la ejecución, son estrategias implementadas por el sistema para tratar a los trabajadores como apéndices de una gran máquina y reducirlos a simples herramientas (Ong 1991:289).

En el caso de los jornaleros, si bien el lugar y el momento específico en el que se debe realizar la pizca o la cosecha están determinados por los criterios estandarizados de los controles de calidad, llevados a cabo por los ingenieros y los agrónomos, éstos 
tienen todavía un importante papel al tener que distinguir entre los frutos que están listos para ser cosechados y los que no. No obstante, su constante control a través de la asignación de un número al inicio de la temporada con el cual se puede llevar un registro de la cantidad de "botes" que cada quien ha logrado cosechar, a los jornaleros se les somete a una estricta vigilancia que equipara la calidad de los productos que ha cosechado con su propia "capacidad" y "calidad" como trabajadores.

A esto se suma la producción de "discursos culturales", como una estrategia de regulación social que busca naturalizar la subordinación de los trabajadores (Ong 1991:291-292), como cuando los agrónomos o los empresarios aseveran, por ejemplo, que "los mixtecos" o "las mujeres" son "mejores" para el corte de tal o cual producto porque sus características físicas o capacidades innatas les permiten realizar esta tarea casi de manera natural, creando así el discurso que justifique la depreciación de su trabajo, pues la naturalización, la esencialización y la cosificación del trabajador es una de las formas más efectivas de justificar los sueldos precarios. No obstante esto también se puede convertir en un medio por el cual determinado grupo de jornaleros pueden llegar a defender su trabajo y su lugar en el proceso productivo, como de hecho ha documentado Adriana Saldaña (2008:77) en Morelos para la cosecha del angú por jornaleros originarios de Tula del Río, Guerrero, que justifican su permanencia en el cultivo del producto argumentando la experiencia que han adquirido a lo largo de los años.

Un poderoso factor que contribuye a que la explotación, el control, el disciplinamiento y la sujeción de los jornaleros sea casi total es que por su misma cualidad de trabajadores migrantes, trashumantes y temporales, les es prácticamente imposible organizarse para luchar por condiciones laborales más justas, o aprovechar los logros de otros sindicatos ubicados en las regiones de atracción ${ }^{6}$. Asimismo, la oportunidad que para ellos representa el trabajo familiar para incrementar los magros ingresos permite no sólo la invisibilización, sino la aceptación de la explotación de toda la unidad productiva familiar, creando un sumamente efectivo mecanismo de auto-

\footnotetext{
6 Marguerite Bey (2001) reporta que en la década de los 90's la CTM cobraba a los jornaleros un peso semanal pero defendía abiertamente los intereses de los patrones. No obstante, esta situación parecía ser compensada al menos en parte por la Central Independiente de Obreros Agrícolas y Campesinos (CIOAC), que no cobraba cuotas y luchaba por contratos colectivos y derechos laborales, como la seguridad social familiar.
} 
explotación que encaja muy bien con el discurso de la auto-ayuda promovido por las políticas neoliberales.

\section{Compresión espacio-temporal en el capitalismo tardío}

Hemos visto hasta este punto como la incorporación de la agricultura mexicana al régimen de acumulación flexible ha requerido y fomentado una mayor flexibilidad y dinamismo no sólo en sus métodos de producción, sino en la fuerza laboral que contrata. Estas nuevas condiciones han implicado la creación de cadenas geográficas de producción formadas por una serie de campos agrícolas donde la producción de cultivos se ha logrado desestacionalizar y, por consiguiente, de trabajadores migrantes en constante movimiento entre unos campos y otros, prontos para atender las necesidades de mano de obra de distintos cultivos, adaptando sus habilidades físicas y sus condiciones de vida para ello.

Debido a que los sueldos suelen ser sumamente bajos y a que dentro de los campos jornaleros las familias deben comprar sus alimentos a precios muy elevados en comercios que prácticamente emulan a las "tiendas de raya" de la época Colonial, con frecuencia no logran hacerse de ahorros que les permitan volver a sus comunidades y enfrentar el periodo que resta del año. La situación empeora para aquellas familias que no han sembrado maíz en sus comunidades de origen y que, al volver, no cuentan con una base de apoyo para la subsistencia, lo cual las obliga a permanecer en el trayecto migratorio indefinidamente, con todas las consecuencias que eso implica para la descomposición de sus ciclos de vida comunitarios relacionados con fiestas y rituales, el ciclo agrícola y el calendario escolar de los niños, entre otros.

Con la importante compresión espacio-temporal que la acumulación flexible ha significado en el mundo capitalista (Harvey 2004:171-173) gracias a la contracción de los horizontes para las comunicaciones, la organización y la fragmentación de la producción, la toma de decisiones, las nuevas posibilidades para el transporte de mercancías, y el tiempo de rotación del capital y el consumo, el espacio se ha tornado más amplio y diversificado, mientras que el tiempo se vuelve cada vez más efímero y lábil. El capital ha desarrollado también la capacidad para controlar y ejercer presiones 
cada vez más fuertes sobre una fuerza de trabajo debilitada por el crecimiento del desempleo, la destrucción y la re-construcción de las calificaciones laborales, la caída salarial y el retroceso del poder sindical. Esta situación ha podido ser muy bien aprovechada para impulsar regímenes y contratos laborales cada vez más flexibles, precarios e inestables; como lo muestra el ejemplo de la explotación jornalera.

A este panorama general se suma, nuevamente, la subcontratación que en el caso de las unidades productivas familiares de los jornaleros, como mencionábamos antes, constituye una excelente estrategia para regular las fluctuaciones del mercado y de la demanda en la fuerza de trabajo. La tendencia actual en los regimenes productivos es apelar cada vez más a una fuerza de trabajo que pueda reclutarse sin ofrecimiento de garantías y despedirse rápidamente y sin costos para la empresa, y quién mejor que los niños y las mujeres para esto. Pero además, la subcontratación no sólo permite y alienta el resurgimiento del trabajo familiar y a destajo, sino de prácticas patriarcales y del sometimiento de los trabajadores, en tanto que el jefe de familia funge como una extensión del patrón que vigila de cerca la realización del trabajo, y porque es mucho más fácil rebelarse contra un patrón explotador que contra un padre o un tío. En todos los casos, apunta Harvey, el "efecto es transformar la modalidad del control sobre la mano de obra y el empleo, socavando la organización de la clase trabajadora y transformando la base objetiva para la lucha de clases" (Harvey 2004:175-176).

Podemos ver entonces que la acumulación flexible no sólo ha sabido aprovechar muy bien el cambio en el rol de las mujeres en la sociedad moderna, como apunta Harvey (2004:178), sino que ha sabido usar a su favor la precarización en las condiciones de vida en el medio rural-campesino para explotar la fuerza de trabajo familiar $y$, sobre todo, la de los niños, en tanto que éstos responden muy bien a su necesidad de sujetos débiles, que no exigen garantías laborales ni mejores sueldos y que son adaptables, incluso físicamente, a la especialización de las tareas productivas.

La serie de transformaciones económicas globales que hemos presentado en los apartados anteriores y la sustitución del fordismo por un régimen de acumulación flexible han significado un fortalecimiento del capital financiero frente al Estadonacional, un cambio en las normas, los hábitos y las actitudes políticas y culturales, así como un desplazamiento general de las normas y valores colectivos de las décadas de 
los 50' y 60's hacia un individualismo mucho más competitivo, entendido como valor central de una cultura empresarial que ha penetrado en muchos aspectos de la vida. Este proceso se ha visto acompañado de una acentuación en la vida moderna de lo efímero, lo transitorio, lo nuevo y lo contingente. La acción colectiva se ha vuelto más difícil, efecto que sin duda ha fortalecido el control sobre la mano de obra (Harvey 2004:189-196).

A través de la aceleración fordista de los procesos sociales y el aumento de las fuerzas productivas a partir de la espacialización del tiempo, los intereses capitalistas lograron ganar terreno sobre antiguas formas y concepciones del tiempo y el espacio, creando una nueva sensibilidad. Posteriormente, con la transición a la acumulación flexible, se ha experimentado "una intensa compresión espacio-temporal que ha generado un impacto desorientador y sorpresivo en las prácticas económico-políticas, en el equilibrio del poder de clase, y en la vida social y cultural" (Harvey 2004:314).

En el sector de la agricultura de exportación y la horticultura, esto se ha manifestado en fuertes cambios en la organización productiva, el transporte, la distribución y el consumo de los productos. Una mayor rapidez en la producción se ha logrado mediante la desintegración vertical de tareas, la producción en pequeñas series, el uso de nuevas tecnologías y un sistema de "migración justo a tiempo" para abastecer la demanda de mano de obra. El efecto fundamental que todo esto ha tenido sobre la sociedad ha sido la acentuación de los valores y virtudes de la instantaneidad y lo desechable. Con la nueva capacidad de desechar objetos, valores, estilos de vida y modas se creó también la capacidad de desechar puestos de trabajo, relaciones, lugares, gente y otras formas de vivir y de ser tradicionales. Se creó un contexto para el resquebrajamiento del consenso y una diversificación de los valores en una sociedad en fragmentación (Harvey 2004:316).

Los trabajadores jornaleros migrantes son, a la vez, víctimas y producto de este nuevo orden económico y de esta nueva sociedad que valora lo adaptable y lo móvil, pero sobre todo los beneficios y la planificación a corto plazo. En un mundo saturado por la producción de símbolos, de imágenes, de nuevos valores y, predominantemente, de nuevas necesidades, los subalternos y los desposeídos se enfrentan a una sobrecarga sensorial sin precedentes; y a la cual mucho contribuyen los discursos 
puestos en marcha por las instituciones gubernamentales y sus políticas sociales, como hemos visto en el primer capítulo.

En este sentido, las políticas sociales también constituyen mecanismos a través de los cuales se alienta la conversión de los campesinos en mano de obra flexible y móvil. Desde el momento en que salen de sus comunidades y una vez que se encuentran en los campos jornaleros, los programas de asistencia social sirven prácticamente sólo para contabilizarlos y categorizarlos, en un intento todavía incipiente e infructuoso de saber cuántos son y a dónde están yendo, pero sin tener un control sobre estos flujos migratorios, que están regulados casi exclusivamente por la demanda de las empresas. Se podría incluso decir que las pocas acciones que las instituciones gubernamentales y las políticas sociales han realizado para los jornaleros (construcción de albergues o comedores, guarderías, etc.) están más destinadas a favorecer su emigración y empleo en los campos que realmente a cuestionar e intentar cambiar las relaciones de explotación a las que están sometidos.

Pero para poder comprender el funcionamiento de la economía política contemporánea y su gubernamentalidad, apunta Rudnyckyj (2004:412), es necesario analizar los procesos de regulación, disciplina y subjetivación que no son llevados a cabo directamente por las instituciones gubernamentales, sino por las prácticas cotidianas vinculadas con la producción de sujetos y significados, como los indígenas y campesinos "pobres", entendidos exclusivamente a partir del discurso de las necesidades, o como los jornaleros migrantes, que se adecuan para cumplir con determinados trabajos y están dispuestos a migrar cuando se les necesite.

Campesinos minifundistas e indígenas se incorporan en cantidades cada vez mayores a la migración jornalera nacional e internacional no sólo por la necesidad de subsistir, sino porque esto implica la oportunidad de entrar en el mercado del consumo de bienes que antes no tenían sentido para ellos, y por la supuesta oportunidad que brindaría el ser un trabajador asalariado, incorporado a la vida moderna y a sus aspiraciones, de ascender en la escala social y poder posicionarse mejor en las relaciones de clase. Pocas son las posibilidades que se tienen de ver que en este tránsito de la ruralidad a la acumulación flexible, ellos constituyen un contingente más de trabajadores que viene a reemplazar a otros grupos, antes tan marginados y 
excluidos como ellos, en una cadena interminable de sustitución de la fuerza de trabajo en el contexto de la explotación capitalista.

Los jornaleros son en sí mismos seres efímeros, flexibles y desechables, en tanto que se adaptan a la movilidad y las necesidades del mercado, pudiendo ser contratados y despedidos a conveniencia. Pero también porque las inefables condiciones de vida y de trabajo a las que están sujetos, trastocan el ritmo de su vida cotidiana, convirtiéndola en un permanente ir y venir entre el trabajo y el exiguo descanso, exponiéndolos constantemente a la muerte y acortando la duración de sus vidas. Nada de esto resulta exageración si comprobamos que la esperanza de vida de un jornalero suele ser en promedio de 45 ó 50 años (dato citado en Rojas 2006:10).

Finalmente, cabe decir que "el nuevo régimen capitalista entraña una fuerte paradoja: mientras menos importan las barreras espaciales mayor es la sensibilidad del capital a las variaciones del lugar dentro del espacio y mayor el incentivo para que los lugares se diferencien a fin de hacerse más atractivos. El resultado ha sido la producción de una fragmentación, una inseguridad y un desarrollo desigual efímero en un espacio económico global altamente unificado de flujos de capital" (Harvey 2004:327). A la vez, la experiencia cambiante del tiempo, del espacio y del dinero ha formado una base material para el surgimiento de sistemas de interpretación y representación específicos. La fragmentación y la dispersión en el pensamiento filosófico y social han mimetizado las condiciones de la acumulación flexible (Harvey 2004:332-334).

Pero esta condición posmoderna que entraña una compresión espaciotemporal y una excesiva transitoriedad y fragmentación en lo político, lo privado y lo social, no es sino una más de las olas sucesivas de compresiones espacio-temporales generadas por las presiones de la acumulación capitalista en su constante afán de aniquilamiento del espacio por el tiempo y de reducción de los tiempos de rotación (Harvey 2004:339).

Podemos incluso pensar que la idea misma de infancia que impera en las sociedades capitalistas, definida principalmente como un estado biológico temporal y transitorio de la humanidad, es también un resultado de estas sucesivas olas de transformaciones en las concepciones del tiempo y del espacio de las que habla Harvey. De hecho, nuestra noción de la niñez y la infancia no adquirió su forma 
"moderna" sino hasta bien entrado el siglo XVIII, como síntoma de una profunda transformación en las creencias y las estructuras sociales de la época, alentadas en gran medida por los avances científicos y escolásticos que tuvieron lugar en las primeras ciudades modernas, como atestigua Jaques Gélis (1990); y sobre las cuales el desarrollo del capitalismo, que fomentó una transición de las formas de vida colectivas hacia una creciente individualidad, ciertamente tuvo mucho que ver, pero a esto me abocaré en el siguiente capítulo. 
Capítulo 3

Infancia y niños jornaleros

En este capítulo me propongo vincular los conceptos teóricos expuestos en los capítulos anteriores con un análisis de la conformación histórica del concepto de infancia y del entendimiento que del trabajo infantil tienen el gobierno federal y algunas empresas agrícolas, enlazando sus discursos con algunas experiencias etnográficas.

\section{La invención de la Infancia}

Durante mucho tiempo, en la Europa occidental antigua dominó una concepción "naturalista" de la vida y del cuerpo que contemplaba a éste último como algo individual y colectivo a la vez. Es decir, como una entidad que era autónoma y al mismo tiempo una extensión del linaje o del grupo social. Los hijos, por lo tanto, siendo cuerpos que emergen de otros cuerpos, eran considerados "vástagos del tronco comunitario", una parte del gran cuerpo colectivo conformado por las sucesivas generaciones. Cuerpos que pertenecían tanto al linaje como a sus padres, eran pues niños "públicos" (Gélis 1990:311-12).

Esta condición era reforzada posteriormente por las circunstancias del nacimiento y la educación, ámbitos ambos en los que lo público y lo privado se hallaban fuertemente entrelazados, estableciendo un vínculo entre la familia y la sociedad, y entre los vivos y los muertos. Por lo tanto, el aprendizaje durante la infancia y la adolescencia debía hacer al individuo apto para transmitir la vida y, llegado el momento, garantizar la permanencia de la familia. Esto suponía una educación que convertía a cada ser en producto de la colectividad, preparándolo para el cometido que de él se esperaba: tener la sensación de pertenecer a una gran familia a la que se estaba vinculado para lo bueno y lo malo (Gélis 1990:313-15). 
En conformidad con esto, a finales del siglo XIV comenzó a aparecer en las clases acomodadas de las ciudades europeas una nueva relación con el niño que se evidenciaba a través de una voluntad creciente por preservar su vida. El rechazo de la enfermedad del niño constituyó entonces un aspecto esencial de la nueva concepción de la vida y del tiempo, que denota que el ser humano había comenzado a verse a sí mismo con otros ojos. Los comportamientos familiares empezaron a modificarse y a este nuevo modelo de relación entre el individuo y el grupo correspondió una nueva imagen y una nueva relación con el cuerpo: "mi cuerpo es mío e intento librarle de la enfermedad y del sufrimiento; pero sé que es perecedero y, por tanto, sigo perpetuándolo a través de la semilla de otro cuerpo, el cuerpo de mi hijo" (Gélis 1990:316-17).

Gélis postula que el hecho de que el cuerpo individual se haya ido desprendiendo simbólicamente del "gran cuerpo colectivo" es lo que nos permite comprender por qué el niño habría de ocupar en lo sucesivo un puesto tan importante en las preocupaciones de los padres y de la sociedad. El niño comenzó a ser una persona a la que se quería por sí misma y no únicamente por el placer que proporcionaba a los adultos. La sombra del grupo familiar y del parentesco dejó, poco a poco, de aplastar al individuo y de borrar su personalidad. Este cambio de actitud respecto al niño, que según Gélis es fundamentalmente una "mutación cultural", posiblemente se originó en la ciudad, lugar de innovación por excelencia; lugar donde también emergiera, desde el siglo XV la "familia moderna", constituida por la pareja y sus hijos. En esta ciudad moderna, que también fue "pensada como cuerpo orgánico", la reducción de la vida social al ámbito de la familia nuclear se fue haciendo manifiesta cada vez con mayor frecuencia a través de la creación y el acondicionamiento de espacios domésticos más íntimos y privados (Gélis 1990:317-19).

No obstante, la permanencia de la idea de la infancia como algo "público" durante los siglos sucesivos, hizo que el niño continuara siendo visto como una persona cuya fisonomía y espíritu eran "blandos" e inacabados y, por tanto, debían ser moldeados para satisfacer el gusto de los padres y la sociedad. Fue así que, durante el siglo XVI, los niños comenzaron a entrar en un universo de imposiciones apenas venían al mundo. Uno de los símbolos más dramáticos de ello son las fajas que le privaban de toda libertad corporal, o los gorros y capillos con los que se practicaban las 
deformaciones craneanas. El niño era visto todavía como una cera blanda sobre la que se podía actuar para ajustarlo a un modelo estético y de comportamiento ideales (Gélis 1990:320).

Durante los siglos XVI y XVII las relaciones entre padres e hijos comenzaron a cambiar, los textos de la época hablaban ya del surgimiento de un "nuevo niño", de conformidad con las relaciones que los "nuevos padres" establecían con sus hijos, cada vez más basadas en el afecto y la preocupación por éstos. Curiosamente, al mismo tiempo surgieron también textos de inspiración moralista que, para luchar contra los "excesos" de afectividad frecuentes en la educación privada de los impúberes denunciaban a aquellos padres que, amando tanto a sus hijos, llegaban incluso a amar sus defectos, corriendo el riesgo de volverlos "unos pillos llenos de malicia". Fue así que durante el siglo XVII se impusieron severas reglas de comportamiento conforme al decoro y esto, explica Gélis, puede ser una de las razones que expliquen por qué la Iglesia y el Estado comenzaron a hacerse cargo del sistema educativo, pues el paso progresivo de lo privado a lo público coincidió con la voluntad del poder político y religioso de controlar al conjunto de la sociedad, fin al que las nuevas estructuras educativas -en particular las de los colegios-, respondían perfectamente (Gélis 1990:322-24).

El sentimiento "moderno" de la infancia tuvo su origen en el siglo XVIII, como síntoma de una profunda transformación en las creencias y las estructuras mentales de la época. Signo de una mutación sin precedentes de la conciencia de la vida y el cuerpo en Occidente, la concepción de la vida como la permanencia de la estirpe y la comunidad fue sustituida por la idea de la familia nuclear, ampliando los derechos que los padres tenían sobre los hijos. En este clima de creciente individualismo, mientras que se trataba de favorecer el desarrollo del niño, la pareja -alentada por la Iglesia y el Estado- delegó parte de sus poderes y responsabilidades al educador (Gélis 1990:328).

Surge entonces la idea de que los niños están siempre a merced de instintos primarios que es preciso contener y de que es importante "someter sus deseos al gobierno de la Razón". Llevar a un niño a la escuela es, por tanto, sustraerle a la naturaleza. Más el éxito de esta nueva educación se debió sobre todo a que templaba el espíritu y a que respondía a las exigencias de un individualismo creciente. No existía entonces contradicción entre la "privatización" del niño dentro de la familia nuclear y 
la educación pública a la que se le confinaba. Surge una conciencia de la vida que ya no implica el respeto de las antiguas solidaridades y que, otorgando mayor valor al individuo, obliga a ponerlo en manos de terceros: preceptores y directores, cuya misión es la de lograr que el niño acceda a conocimientos que no podría recibir de sus padres. Éstos, por otra parte, comprenden que son incapaces de darle una formación distinta de la que antaño recibía sólo de la comunidad. Se efectúa así una doble transición: una que va de la familia troncal a la familia nuclear, y otra que va de la educación pública, comunitaria y abierta, destinada a integrar al niño a la colectividad para que adopte los intereses y los sistemas de representación de la estirpe, a una educación pública de tipo escolar, destinada a integrarle, pero también a dominarle y formarle, guiando el desarrollo de sus capacidades y su comportamiento (Gélis 1990:324-25).

Por tanto, la modificación de la condición del niño no fue resultado sólo de la transformación de las estructuras familiares durante los siglos del clasicismo. La Iglesia y el Estado fungieron un papel clave en este cambio, pues la afirmación de la idea y el sentimiento de la infancia vino acompañada de toda una serie de disposiciones legales que respondían a la vez a escrúpulos de moral religiosa y a preocupaciones de carácter público. Esta legislación es asimismo el testimonio de los primeros intentos de construir una política de protección a la infancia, que requería de una intervención más amplia del Estado en las cuestiones demográficas, por ejemplo (Gélis 1990:325).

Según Phillipe Ariès no fue sino hasta el siglo XVIII que en el mundo europeo occidental comenzó a hacerse una distinción entre la infancia y la adolescencia. Antes de ello estos términos eran utilizados indistintamente, del mismo modo que en Francia la palabra "niño" era utilizada indiscriminadamente para nombrar a un crío, a un muchacho, a un pequeño sirviente o a un hombre joven. Según apunta el autor, este uso tan ambiguo de la palabra se debía a la indiferencia con la que durante la época se veía a los fenómenos estrictamente biológicos. En esa época nadie hubiera pensado que la infancia culmina en la pubertad. Dominaba la idea de la infancia como algo fuertemente vinculado a la dependencia, y los términos utilizados para denominarla eran los mismos que se utilizaban en el vocabulario de la subordinación feudal (Ariès 1962:25-26). 
Los términos asociados con la infancia pervivieron durante décadas en el lenguaje hablado para indicar a aquellos hombres de origen humilde cuya sumisión era absoluta (Ariès 1962:26), y posiblemente podamos encontrar aquí el origen del uso del término "infantil" para definir a alguien que es inmaduro, pueril, vano, caprichoso, o incompleto, así como de una visión que naturaliza a la infancia tomándola como una mera etapa biológica. De hecho, Ariès (1962:28), menciona que durante el siglo XVII, época que se caracterizó más bien por un desprecio hacia la niñez, surgieron varias expresiones y frases que se usan hoy en día, relacionándola con actitudes caprichosas, maliciosas e inadecuadas.

En su obra Centuries of Childhood, Phillipe Ariès nos muestra que durante toda la Edad Media y hasta el surgimiento de la edad moderna, los niños eran incorporados de inmediato al grupo de los adultos apenas eran considerados capaces de valerse por sí mismos, es decir, cuando podían caminar y hablar sin dificultad y eran capaces de realizar tareas sencillas. La vida se desenvolvía en un fuerte ambiente de colectividad, con poco espacio para la soledad y la privacidad, y la familia cumplía con la función de transmitir la vida, la propiedad y el nombre. La educación como la conocemos hoy era algo desconocido para la época (Ariès 1962:411).

Hoy en día, en cambio, nuestra sociedad depende en gran medida del éxito de su sistema educativo, sus bases están fuertemente fincadas sobre una idea específica de la educación, del sistema educacional y, principalmente, sobre una conciencia de la importancia que la educación tiene para los niños. Pero ésta era una preocupación inexistente en la Edad Media, puesto que no había una idea de la educación infantil ni siquiera similar a la de ahora, dado que los niños eran concebidos solamente como los compañeros de los adultos (Ariès 1962:411).

El gran acontecimiento consistió entonces en el surgimiento, al inicio de la edad moderna, de un interés en la educación. No obstante, puesto que los humanistas continuaron estando interesados mayormente en la idea de una cultura general, mostraron poco interés en la educación de la niñez, desinterés que moralistas, clérigos, abogados y reformistas aprovecharon para tomar las riendas de la "moralización de la sociedad", entronizando el orden y los valores religiosos. Fue así como se impuso la primacía de la educación y se dio lugar a la transformación de la escuela pública y liberal en un colegio estrictamente disciplinado. Varias órdenes religiosas comenzaron a 
enseñar a los niños sometiéndolos a un tratamiento especial, sosteniendo que éstos no estaban preparados para la vida, por lo que se les debía disciplinar, adoctrinar y preparar para que pudieran unirse a la población adulta (Ariès 1962:412), en bien de la sociedad. Fue así como la "recta disciplina" de la que nos habla Foucault (1978a:175), es decir, el arte del buen encauzamiento de la conducta, comenzó a tener la función de enderezar conductas, mas no para reducirlas, sino para multiplicarlas y usarlas, pues la disciplina "fabrica" individuos en tanto que es la técnica específica de un poder que se da los individuos a la vez como objetos y como instrumentos de su ejercicio.

La nueva concepción de la escuela como el ámbito exclusivo para la educación de los niños fue poco a poco arraigándose en el corazón de la sociedad, transformándola por completo. La familia comenzó a asumir la función moral y espiritual de moldear los cuerpos y las almas de los niños, y el aprendizaje tradicional, colectivo y empírico fue reemplazado por la escuela regida por la disciplina y el orden. Familia y escuela trabajaron juntas para retirar y alejar al niño de la vida del adulto (Ariès 1962:412-13) y, con ello, de sus espacios de socialización, aprendizaje, participación y poder.

Con su estricto sistema disciplinario, en ocasiones carcelario, la escuela se empeñó en silenciar y restringir a una niñez que hasta entonces había podido gozar libremente de la compañía y los espacios de los adultos, enclaustrándola -durante los siglos XVIII y XIX principalmente- en internados, e imponiéndole los castigos que hasta entonces habían estado reservados para los estratos más bajos de la sociedad. Según Ariès, esta severidad no fue sino la expresión de un cambio radical en la sensibilidad, que pasó de la total indiferencia hacia la infancia que caracterizó a las sociedades occidentales europeas de épocas tan remotas como el siglo X, a un "amor obsesivo" que dominó a toda la sociedad a partir del siglo XVIII (Ariès 1962:413).

Este nuevo ejercicio disciplinario sobre la infancia sin duda responde también a lo que Foucault denominó el surgimiento del "poder de la Norma" en las sociedades modernas, cuando lo Normal se establece como principio de coerción en la enseñanza con la instauración de una educación estandarizada y el establecimiento de las escuelas normales. La vigilancia y la normalización -no sólo de los niños- se convierten así en los grandes instrumentos del poder (Foucault 1979a:188-89). El "profesor-como-moralista" reemplazó a los padres, a Dios y al Estado ante los niños, 
para adoctrinarlos sobre "lo bueno y lo malo" en la escuela y en la sociedad, y para hacer que todos se sintieran hijos del mismo Estado, pero un maestro que combina estos poderes contribuye mucho más a la deformación del niño que las leyes que dictan su menoría de edad legal o económica, o que restringen su libertad de acción (Illich 1978:65).

No es necesaria mucha imaginación para dilucidar cuál sería el siguiente eslabón en esta cadena de transformaciones históricas que han acompañado una transición que va de la comunidad, a la familia, al individuo. En un principio los niños ni siquiera eran vistos como algo distinto a sus padres o al resto de la comunidad. Más adelante, el énfasis en la familia nuclear cambió las cosas y otorgó a los niños un lugar y un rol en la sociedad, lo cual derivó en que los padres y el Estado ejercieran un mayor control sobre ellos, principalmente a través de la figura del maestro. Subsecuentemente el Estado, apoyándose en valores morales y religiosos, comienza a intervenir en la dinámica familiar y a intentar controlar la vida y el futuro del niño por considerar su bienestar como un asunto de interés público. Fue entonces que se crearon las primeras disposiciones legales que intentaban "proteger" al niño con una intervención más amplia del Estado.

Actualmente, en la era del capitalismo tardío se tiende a la sustitución de la familia y de la colectividad por el individuo, en el cual están basados los derechos humanos y también las leyes y los deberes fundamentales del Estado-nación moderno. Ya no es la familia ni la perpetuación de la estirpe el medio por el cual el individuo-niño alcanzará su máxima realización, ahora lo son la escuela y el libre mercado. Por consiguiente, el siguiente eslabón en la gesta histórica de la infancia y la niñez moderna son las instituciones internacionales y las políticas públicas.

\section{Gubernamentalidad e infancia indígena}

Siguiendo a Nancy Munn (1992:109), podemos decir que controlar el tiempo no sólo es una estrategia de interacción, sino un medio de poder y gobierno; y que controlar el calendario u otros instrumentos cronológicos no sólo es ejercer un control en ciertos aspectos de la vida cotidiana de las personas, sino conectar estos niveles de 
control con un universo más comprensivo que implica valores críticos y potencias en las que está basada la gobernancia.

Así, definir a la infancia como una etapa transitoria, como un periodo o un episodio momentáneo en el desarrollo de la humanidad es tener el poder de naturalizarla y, por tanto, de controlarla. Y pocas veces los niños son más naturalizados y neutralizados que en las políticas públicas y las instituciones destinadas a "atender" a la infancia, basadas en concepciones unilineales y universalistas que generalmente evitan abundar en las especificidades socio-culturales que hacen posible la existencia de distintas concepciones de la infancia alrededor del mundo. En este sentido, el concepto de gubernamentalidad es particularmente interesante y útil, no sólo porque nos permite analizar la serie de prácticas que tienen lugar en la esfera de las políticas estatales y las entidades supra-estatales, sino particularmente porque nos permite reflexionar sobre las prácticas que tienen lugar en el ámbito de la vida cotidiana (Rudnyckyj 2004:410) y que están destinadas a la definición y el control de sujetos específicos.

Tener el poder de definir y controlar la duración de algo, como cuando la UNICEF determina que son niños todas las personas menores de 18 años, implica tener la capacidad de mediar entre el individuo y un orden más amplio del ser social para poder controlar incluso las subjetividades y los cuerpos. ¿̇ajo qué criterios se determina, por ejemplo, que el cuerpo de una mujer de diecisiete años, que quizás tiene ya dos hijos, sigue siendo el de una niña? ¿Dónde comienza y dónde termina un interés por el cuerpo social y un afán de controlar los cuerpos individuales? Todas estas determinaciones tienen que ver con la construcción de una gobernancia cultural ejercida a través de una definición del tiempo corporal de las personas para coordinarlo con los valores de un tiempo global que responde a un universo de poder más amplio, como el del capitalismo posfordista.

La regulación del tiempo laboral por el capitalismo occidental, junto con su mercantilización y estandarización, es sólo un ejemplo de cómo el control del tiempo es una forma de reconstrucción de la autoridad usada para gobernarse a sí mismo en la vida cotidiana, es decir, una gobernancia fundada en la persona y en su actividad cotidiana como parte de un orden mundial más amplio (Munn 1992:110-111). 
Munn (1992:111) apunta que al establecer un tiempo estándar con base a los meridianos, la astronomía y la ciencia se aliaron para investir a los relojes de una autoridad intachable que poco a poco se fue fusionando con la autoridad humana. El reloj se fue concretizando en la experiencia cotidiana, incrustándose en las actividades y las experiencias a través de los silbatos de las fábricas y las alarmas en los talleres, hasta introducirse en el cuerpo y fusionarse con el tiempo corporal y el espacio vivido; para luego volver al reloj como objeto visible que corresponde al un orden cósmico más amplio de la industria, la ciencia y la tecnología.

Definir y situar al "otro" en un tiempo distinto, atrasado, primitivo, tradicional o infantil es una estrategia común del poder político y económico, casi siempre con el fin de aplicar un conocimiento sobre una población que permita "alcanzar ciertos efectos que son considerados benéficos para los individuos, la colectividad y el Estado" (Rudnyckyj 2004:410). Algo similar sucede con la infancia. Definida a lo largo de la historia mediante criterios científicos biológicos, psicológicos y sociales, la infancia ha sido caracterizada como un periodo con una duración determinada, y se ha ido incorporando a nuestra experiencia cotidiana de ser articulando nuestras experiencias con un orden político mucho más amplio, con valores y poderes particulares y designando ordenes, jerarquías y espacios. Esto ha llevado a que en las sociedades industriales modernas la niñez sea definida primordialmente como un periodo psicofísico universal. Asimismo, dado que se le ha conferido a la infancia una cualidad transitoria, su mérito reside en que constituye una etapa de "preparación" para alcanzar un estado más "deseable" de madurez adulta y, por lo tanto debe ser salvaguardada de todo vicio y todo mal.

Pero la infancia, al igual que el tiempo, finalmente no es sino una categoría cultural sustentada en determinadas prácticas colectivas y que en cierto sentido responde a una gubernamentalidad que se hace visible en las técnicas, las teorías y las estrategias destinadas a producir ciertas actitudes y habilidades. Después de todo, no existe ningún conocimiento sobre el Otro que no sea a la vez "un acto temporal, histórico y político" (Fabian 1983:1).

En el caso de la infancia "vulnerable" o "marginada" empresas, políticas sociales e instituciones nacionales e internacionales contribuyen a la creación de un tipo específico de gubernamentalidad con sus discursos y prácticas cotidianas. En este 
sentido sería importante un estudio de las relaciones que los capataces o los productores establecen con los niños o con las familias con niños en los campos jornaleros, qué estrategias usan para controlar y medir el rendimiento laboral de los niños y bajo qué mecanismos se racionaliza su participación en la producción agrícola. Son este tipo de tecnologías del saber las que nos revelan una voluntad por perpetuar ciertas nociones, pero también ciertas actitudes, habilidades y determinadas "disposiciones hacia uno mismo y hacia los otros" (Rudnyckyj 2004:412).

Un ejemplo de esta gubernamentalidad que pretende definir al otro a partir de características estereotipadas que son erróneamente consideradas "culturales", como si esto quisiera decir "naturales" o "normales", es la desafortunada declaración que a finales del 2007 hizo un burócrata de la Secretaría de Desarrollo Social (SEDESO) para justificar las carencias que esta secretaría no ha podido subsanar en algunos campos jornaleros de Chihuahua, diciendo que los jornaleros agrícolas "de por sí son sucios y no se bañan ni limpian los cuartos", y que por eso "no vale la pena construir albergues" para ellos, aduciendo incluso que "los jornaleros tienen otra cultura, son gente que llega del sur del país". Por si fuera poco, esta persona todavía se atrevió a quejarse diciendo que los jornaleros son "un problema social para el estado"7. De esta manera y con una retórica racista no sólo se justifica el hecho de que los jornaleros sean sometidos a condiciones francamente inhumanas de vivienda, sino que por sus supuestos orígenes "culturales" y su "atraso" se espera que estén conformes con ello.

Algo muy similar ha ocurrido en el caso de la infancia rural y marginada de México, que durante décadas ha sido construida como desvalida, victimizada, e incompleta por no poseer las "oportunidades" de "desarrollo" que han sido pensadas para una clase mestiza, asalariada, urbana y escolarizada. De todos los sujetos que conforman nuestra sociedad, probablemente sean los niños indígenas quienes más han sufrido las consecuencias de la consolidación de la escuela y el sistema educativo en general como el ámbito de reproducción de la cultura hegemónica, el orden social dominante, jerárquico y discriminatorio, así como de su uso político para la construcción de la ideología sobre la cual se ha fincado la identidad nacional y una gubernamentalidad específica. Con la creación del indigenismo, la escuela se concibió como el ámbito y el instrumento más adecuado y significativo para la

\footnotetext{
7 La Jornada, viernes 26 de octubre del 2007.
} 
aculturación del indio. ¿̇Y sobre quién habría de actuar de manera más incisiva y perdurable la escuela sino sobre el cuerpo, la mente y la identidad del niño indígena, todavía no por completo plagado de las 'perversiones' y los 'defectos' de su cultura? Aun cuando fuese en supuestos "planos de igualdad", el indigenismo buscó una "integración ideológica" de la población india para que ésta pudiera alcanzar su participación plena en la conformación de las clases sociales, y en el desarrollo y el progreso nacional. Para que ésta finalmente pudiera librarse del "estado indeseable" en el que se le mantenía y pudiera así integrarse a la sociedad como ciudadanos con derechos, obligaciones y lealtades plenas (Aguirre Beltrán 1973:279-80). La educación y la castellanización constituyeron entonces la vía a través de la cual se pretendía lograr la aculturación del indígena y, con ello, posibilitar su integración a la nación (Aguirre Beltrán 1957:192).

Desafortunadamente, aun cuando los principales postulados del indigenismo han sido incluso fervientemente rechazados desde hace ya tiempo, un orden de ideas bastante similar, todavía despectivo y paternalista, continúa siendo predominante hoy en día en gran parte de las instituciones gubernamentales del país, que piensan a los indígenas como entes subdesarrollados -económica e intelectualmente-, que deben ser redimidos de su pobreza. Dentro de esta perspectiva, el niño indígena ha sido concebido como un individuo que, habiendo crecido en un ambiente de marginación y con pocas herramientas para desarrollarse plenamente, es la máxima expresión del descuido y el desamparo, víctima de toda clase de abusos y carencias.

Esta clase de concepción, tan piadosa y compasiva como irreflexiva y poco autocrítica, ha llegado inclusive al punto de considerar que, cuando el niño indígena es también un migrante $\mathrm{o}$ un trabajador jornalero monolingüe, las causas de su explotación son precisamente su condición lingüística y su origen étnico, sin reparar siquiera en las estructuras políticas y macroeconómicas a las que el niño, junto con su familia y su comunidad se encuentran sujetos, auténticas causas de la pauperización de sus condiciones de vida y de trabajo (ver PRONJAG 2002, SEDESOL-UNICEF 2006).

Podemos entonces ver que en la voluntad de los ideólogos del indigenismo y los precursores de la educación indígena ${ }^{8}$ de que la escuela fungiera como un

8 Moisés Sáenz (en Aguirre Beltrán 1970), Aguirre Beltrán (1957 y 1973), Rafael Ramírez (1982) y Samuel Ramos (1979). 
mecanismo homogeneizador y unificador de la población en favor del progreso nacional, persistía una inclinación por contemplar a la niñez rural e indígena como el fragmento de la sociedad que podía ser educado y moldeado en aras de un ideal superior, colectivo y nacional. Pero la escuela no constituía solamente el espacio para la educación de los futuros ciudadanos, era también el espacio para la transformación y el cambio cultural, y una de tantas otras "agencias para el mejoramiento social" que se encargarían de todos aquellos niños pobres e indígenas que no sólo necesitaban educarse, sino alejarse el "mayor tiempo posible de sus chozas miserables" (Aguirre Beltrán 1970:16).

En consonancia con lo que se planteaba durante la llustración respecto a la educación y la infancia, en las primeras décadas de la existencia de la Secretaría de Educación Pública -y principalmente durante el indigenismo-, el indígena (y el niño indígena por ende) era pensado como un ente anacrónico y pasivo, cuyo carácter debía ser disciplinado y moldeado según las exigencias del nuevo Estado-Nación. De modo que éste era descrito como "manso y apacible", y se pensaba que su receptividad respecto al orden social impuesto a través de la escuela sería indudable, aún cuando su actitud socarrona fuese bien conocida (Saenz 1926 en Aguirre Beltrán 1970:24).

Como agencia civilizadora, la escuela debía efectuar el paso de una mentalidad folklórica a una civilizada. Sáenz sostenía que la escuela, encargada de ilustrar, enseñar a leer y establecer normas era, por definición, opuesta a la cultura, entendida como "la calidad especial de un grupo humano". La educación en México era, por tanto, un esfuerzo para hacer, con el diseño cultural mexicano, una civilización. El niño indígena ofrecía entonces un campo ideal de acción, siendo primitivo pero inmaduro y todavía no formado por completo, debía ser castellanizado para poder pertenecer y participar en el proyecto de Nación. La integración debía producirse "mental y materialmente", hasta lograr la unidad nacional (Saenz 1926 en Aguirre Beltrán 1970:42-44).

Esta perspectiva, por demás romántica y etnocéntrica cuando no etnocida, donde la escuela representa el pináculo del progreso y la solución a todos los problemas de la población marginada del país -sea ésta indígena o no- ha persistido todavía hasta nuestros días en la ideología sobre la cual se sustentan la mayoría de los programas de combate a la pobreza implementados como parte de una política 
social paternalista, asistencialista y compasiva, como el Solidaridad, el Progresa y el Oportunidades. Por lo tanto, desde hace ya más de tres décadas se ha contemplado a la educación de los sectores más pobres y marginados como la solución para eliminar los "vestigios de pobreza" (Favela et al 2003:45) que han caracterizado a estos individuos. La educación fue contemplada como la panacea que habría de solventar todos los problemas de las pauperizadas familias, rompiendo con el "círculo vicioso" de la exclusión y la miseria. Se construyó a la educación, el aprovechamiento escolar y el combate a la deserción escolar, como la solución para todos los males de pobres y misérrimos, rurales y urbanos.

Esta monumental transformación debía, desde luego, comenzar con los niños. Por lo tanto, gran parte de las actividades de este tipo de programas desarrollistas se han centrado en la "concientización" de los padres sobre la absoluta necesidad de educar a sus hijos, para que éstos sean capaces de superarse y superarlos a ellos, así como de la necesidad de dotarlos con las aptitudes básicas para aprovechar de mejor manera la educación: buena alimentación y servicios de salud, argumentando que así serían más productivos y aptos para el trabajo. Asimismo, se han combatido y desprestigiado todas las actividades que imposibilitan o distraen a los niños de su actividad fundamental: la escuela. Por su parte, el deber primario y primordial de los niños como individuos y ciudadanos en potencia, es el de concluir con su educación básica, reproduciendo el discurso de que la educación solventará en un futuro todos sus problemas económicos.

Ya en los comienzos de la década de los 70 Ivan Illich hacía notar, no sin cierta preocupación, que los gobiernos latinoamericanos y las agencias internacionales habían puesto, durante demasiado tiempo, sobradas esperanzas en la capacidad de la educación para sacar a la mayoría de la población rural de sus condiciones de marginación y hacerlos encajar en el progreso iniciado por la introducción de la tecnología en la vida socioeconómica. Se asumía que la educación eventualmente produciría una amplia clase media cuyos valores se asemejarían a aquellos de las clases altas de los países industrializados, a pesar de que sus modos de subsistencia continuaran caracterizándose por la escasez (Illich 1984b:91).

Hoy en día algunos autores sostienen que la intención del Estado mexicano ha sido siempre la de mantener la dominación étnica a través de sus instituciones y que la 
escuela, siendo una de las instituciones fundamentales, ha servido sin duda para este fin (Maldonado 2002:126), situación que afortunadamente ha sido matizada por intelectuales indígenas y no indígenas que han trabajado en la construcción de importantes críticas y nuevas posibilidades educativas. No obstante, en muchos casos la escuela ha logrado introducirse hasta el núcleo mismo de la vida familiar, campesina e indígena, transformándola con sus discursos paternalistas y su afán concientizador, demagógico y etnocéntrico. Influyendo incluso en el modo mismo en que estas familias conciben a sus hijos y haciendo a los padres sentirse culpables por incorporarlos a sus labores agrícolas y domésticas tan pronto los niños adquieren la capacidad física, bajo el absurdo discurso de estar contribuyendo a la explotación de sus propios hijos.

Pero la escuela, como ha señalado Illich, también ha sido un efectivo instrumento de custodia para todas aquellas personas que han sido declaradas indeseables, encargándose del excedente de población proveniente de las calles, la familia o la fuerza de trabajo. Asimismo, las escuelas han sido importantes bastiones para la creación y el sostenimiento del status quo, así como importantes herramientas para atemperar el potencial subversivo en una sociedad alienada, puesto que si la educación es confinada solamente a las escuelas, sólo aquellos que han tenido acceso a ellas podrán intentar escalar a los niveles superiores; introduciendo en las mentes de los desescolarizados la aceptación de la ideología que proclama la superioridad e incuestionable autoridad de aquellos que han tenido una mejor o más prolongada educación (lllich 1984b:93-98).

En este contexto resulta significativo retomar las palabras de Moscoso (2008:264) respecto a que para poder entender a profundidad el papel que la infancia juega en la sociedad contemporánea y su papel para las ciencias sociales, es fundamental reflexionar acerca de cuáles son las instancias desde las cuales se ha construido e institucionalizado el pensamiento en torno a los niños y como una manera de constituir un aparato moderno de reproducción de saberes que legitiman ciertas prácticas relaciones de poder y ejercicios cotidianos de ser, estar e interpretar en el mundo en las cuales los niños pueden estar siendo pensados desde la otredad, reproduciendo la exclusión y perpetuando las diferencias.

Muchas veces la colonialidad del poder y del conocimiento se extiende hasta nuestros días en un largo proceso que nos muestra que el poder sólo ha cambiado de 
manos. Es en este contexto que se produce una "diferencia colonial" en la que se construye al niño como "un sujeto fracturado en su identidad, valorado negativamente por el discurso hegemónico que clasifica al mundo según un sistema geopolítico constituido, de configuraciones raciales y de estructuras jerárquicas de comprensión y de conocimiento" (Moscoso 2008:264), pero también de edad y de cualidades basadas en un modelo "adultocéntrico".

En tanto que "fijar los significados ha permitido naturalizar las diferencias" (Moscoso 2008:266), debemos hacer visible aquellos aparatos de pensamiento que funcionan por medio de sistemas de exclusión. En este sentido, las reflexiones desarrolladas por el feminismo, apunta Moscoso, nos han mostrado cómo determinados conceptos y categorías contribuyeron a la invisibilización de las mujeres y los mecanismos de desigualdad a los que estaban sujetas. De igual manera, los estudios de género nos ayudarían a entender por qué niños y niñas no han ocupado sino un lugar invisible en la construcción del pensamiento o, por qué, al igual que a las mujeres, durante mucho tiempo no se les reconoció sino un "estatus secundario" dentro de la sociedad y las disciplinas.

Siendo que, como postula Moscoso (2008:268) para poder hablar de los "otros" es necesario, hasta cierto punto, mantenerlos fuera del tiempo de la antropología, podemos decir que el Estado, para poder controlar, disciplinar y someter al escrutinio a la niñez, ha necesitado mantenerla fuera de una plena participación en la sociedad, confinándola al universo único de la escuela y la familia. Considerándolos incompletos e inmaduros, se ha pensado en los niños sólo como "ciudadanos en potencia", cuyo deber es formarse para convertirse en individuos disciplinados y productivos.

Desde luego, esta categorización ha estado acompañada de prácticas, saberes y valores que han delimitado los modos de vida de la infancia, menoscabando su importancia y su valor como un modo distinto de ver y experimentar el mundo, y excluyéndola de las distintas esferas de la vida social (cultural, económica y política) para construirla como el espacio de la "ajenidad, la otredad y la exclusión" (Moscoso 2008:270).

Siguiendo los planteamientos de Moscoso (2008) y Spivak (en Asensi 2006), podemos decir que durante el proceso histórico de formación del pensamiento occidental y las instituciones modernas (y principalmente de la escuela), la infancia ha 
sido construida fuera de los límites de la discursividad, es decir, como una entidad subalterna, en tanto que subalterno es todo aquél que no puede hablar puesto que no hay institución que escuche y legitime sus palabras. Asimismo, hemos construido y perpetuado una visión de la infancia como subordinada, en términos de clase, casta, género, oficio y generación, lo cual explicaría por qué "la teoría social dominante excluye sistemáticamente el pensamiento y la experiencia de los niños" (Moscoso 2008:270). Hemos permitido además que el poder de los discursos hegemónicos construya al niño como el sujeto débil, como el "otro", colocando sobre él el peso de una concepción jerarquizada de la producción del conocimiento que descalifica y silencia sus modos de ver, pensar y actuar en el mundo.

\section{La visión institucional del trabajo infantil}

La importancia de reflexionar y contestar las ideas y las categorías a partir de las cuales actualmente se piensa a la infancia es fundamental para develar nuevas formas de gubernamentalidad apoyadas por nuevas ideologías y prácticas. Pero también para comprender mejor cuál es el papel que la infancia indígena, rural y migrante desempeña en la reproducción económica, social e incluso política de sus comunidades y de la sociedad nacional. Es a través de un estudio de la participación y las relaciones que los niños sostienen con el mercado laboral agrícola, así como de las representaciones que de ellos se construyen en los discursos institucionales y de políticas públicas, que podemos entender cómo se construyen hoy en día, en nuestra sociedad posfordista y globalizada, nuevas formas de otredad y de exclusión. De este modo comprenderemos también como todos estos factores tienden a la creación de sujetos lábiles, prescindibles y móviles que sean fácilmente manejables por las políticas públicas y puedan satisfacer las demandas del mercado.

En este sentido, pocos terrenos son tan fértiles para este tipo de reflexiones como el del tema del trabajo infantil, lleno de las implicaciones de los discursos que hemos construido y reproducido en torno a la infancia indígena, migrante y trabajadora a partir de políticas públicas, programas asistencialistas e intereses desarrollistas que la mayoría de las veces sólo han servido para "problematizarla", estigmatizarla y 
encasillarla en una visión extremadamente simplista, paternalista y miserabilista que en nada contribuye a clarificar las verdaderas causas de su marginación y explotación.

Los niños que forman parte de la población empleada en los campos jornaleros suelen aparecer en los estudios sobre el tema jornalero cuando se quiere mostrar una de las caras más devastadoras de la explotación capitalista, cuando se presentan las cifras del deterioro económico y social que las políticas neoliberales han impuesto sobre las familias campesinas, o bien para indicar, a través de las tasas de mortandad y desnutrición, las peores consecuencias de la crisis rural y alimentaria en México. Sin embargo, poco se ha hecho todavía para estudiar de fondo el impacto que la participación infantil tiene en la agricultura de exportación, en términos tanto económicos como sociales y políticos y en el plano tanto familiar como empresarial o industrial desde una perspectiva que los reconozca como los actores sociales que son.

Todavía se sabe menos acerca de las estrategias que los niños, aún a sus cortas edades, implementan en los campos agrícolas para adquirir las capacidades y los conocimientos necesarios para poder ser considerados aptos para el trabajo, para hacer frente a las duras jornadas laborales o a la enfermedad y el hacinamiento, para asumir el papel de "hombre de la casa" cuando los padres han migrado y sobre ellos ha recaído la responsabilidad de trabajar al lado de la madre por el sostenimiento familiar, o bien para intentar hacer compatible todo lo anterior con la asistencia a la escuela, cuando la hay en los campos.

Uno de los principales factores que han contribuido a desviar la atención de las verdaderas causas de la explotación infantil es el prejuicio bastante generalizado de que la población jornalera es víctima de la marginación, la mortandad y la pobreza por culpa de su ignorancia, sus costumbres, su desidia y su holgazanería. O bien, que los niños indígenas son explotados en los campos jornaleros porque sus padres así lo han decidido, pues así se los dicta su cultura. Desafortunadamente esta es la visión que suele primar, o al menos así se nos da a entender, en algunos programas gubernamentales destinados a la población jornalera, como el Programa Nacional de Jornaleros Agrícolas (PRONJAG), que ahora se ha descentralizado en el Programa de Atención a Jornaleros Agrícolas (PAJA).

Un ejemplo más bien preocupante de esto es el programa de "desmotivación" y "desaliento" del trabajo infantil que el PRONJAG promovía en el 2002 a través de su 
programa "Proceder", con el objetivo de "concienciar" a los padres indígenas de que haciendo trabajar a sus hijos están violando sus derechos, y difundiendo la absurda idea de las familias indígenas gustan de explotar y depender del trabajo de sus hijos (ver PRONJAG 2002). Así lo dejaba sentado la Secretaría de Desarrollo Social todavía en el 2006, año en que publicó su último informe sobre el Programa de Atención a Jornaleros Agrícolas (PAJA). En su Diagnóstico sobre la condición social de las niñas y niños migrantes internos, hijos de jornaleros agrícolas, esta secretaría continúa planteando sus iniciativas solamente en términos de "desalentar" el trabajo infantil, esta vez principalmente a partir de la incorporación de los mejores en programas de transferencias económicas condicionadas (SEDESOL-UNICEF 2006:6), como el Oportunidades.

Lo que este Diagnóstico busca, grosso modo, es ofrecer un "perfil socioeconómico y demográfico de las hijas y los hijos de las familias jornaleras que se encuentran entre los seis y los catorce años de edad, de acuerdo a su condición de trabajo, en los campos de cultivo de 23 regiones agrícolas" en 10 estados del país (SEDESOL-UNICEF 2006:9). El problema es que dicho diagnóstico está fundado sobre un grave inconveniente: que la SEDESOL no cuenta con una fuente estadística propia para la identificación y el conocimiento de la población que constituye el objeto del PAJA, por lo que ha tenido que utilizar datos de otras instancias que no han sido actualizados, principalmente de la Encuesta Nacional de Jornaleros Migrantes (ENJOMI). Peor aún resulta saber que, por muy útil y relevante que esta encuesta haya resultado en su momento, ésta fue realizada en 1998, es decir que para el momento en que se elaboró el Diagnóstico (2006) ésta tenía ya ocho años de haberse realizado y no había sido actualizada. Resulta entonces que en el momento en que el Diagnóstico fue publicado, se podría decir que resultaba ya prácticamente obsoleto, dado que su abordaje y su análisis del problema son fundamentalmente cuantitativos.

Además de estar mal redactado y algo desorganizado, el Diagnóstico ofrece una gran cantidad de gráficas y tablas estadísticas que conducen a una serie de datos más que varias veces parecen contradecirse y que otras tantas simplemente culminan en conclusiones fútiles e incluso obvias. Al final de la lectura, uno se queda con la impresión de que el documento se elaboró con demasiada premura, sospecha que se ve confirmada cuando uno descubre que su realización tomó sólo 3 meses, con trabajo 
de campo, entrevistas a instituciones y reuniones de trabajo incluidas. Una prueba más del grado de importancia que se le da a este tipo de cuestiones a nivel federal.

El documento termina siendo más un recuento de los síntomas y los signos del problema al que se aboca, que un análisis o una reflexión sobre sus causas. De modo que la cuestión del trabajo infantil es analizada principalmente a través de una "semblanza" de la "estructura económica y familiar en la que éste se reproduce". Basándose en el relato del caso de una sola familia zapoteca con tres hijos que migró a Culiacán para emplearse en los campos jornaleros, y en la cual el aporte económico de los niños representa el $60 \%$ del ingreso familiar, así como una escueta entrevista con un par de niñas trabajadoras (SEDESOL-UNICEF 2006:37 y 43). Con esta entrevista, sin embargo, la SEDESOL pretende mostrar que ha introducido el 'punto de vista del nativo' en su estudio y quizás hacernos creer que promueve la participación de los sujetos, dos estrategias que desde hace un par de años están siendo promovidas por instancias internacionales que trabajan con poblaciones marginadas, como el Programa de las Naciones unidas Para el Desarrollo (PNUD) y la UNICEF.

No es difícil llegar a la conclusión de que uno de los discursos que sutilmente permean todo el Diagnóstico es que el trabajo infantil es un problema intrínseco a las familias indígenas y/o pobres, pero dejando fuera de toda consideración cuáles son las causas estructurales -sociales, económicas y políticas- de que una enorme proporción de la población indígena y campesina del país sea presa de condiciones sumamente adversas de marginación y pobreza, y por consiguiente se vea en la necesidad de migrar a otras regiones en busca de un trabajo explotador y precario para poder subsistir.

La cuestión a pensar entonces es por qué la SEDESOL se empeña en analizar las dinámicas de las pauperizadas familias jornaleras en torno al trabajo infantil y no las de las empresas agrícolas, que obtienen enormes tasas de ganancia a expensas de éste, por ejemplo. Constantemente, la SEDESOL sitúa a la familia jornalera como el escenario principal para la focalización de políticas públicas destinadas solamente a desincentivar el trabajo infantil (SEDESOL-UNICEF 2006:40) argumentando -y no sin razónlas repercusiones que tiene sobre la educación la salud y la alimentación de los niños y niñas migrantes que se encuentran entre los seis y los catorce años. Pero, aún cuando es bien sabido que las peores consecuencias del trabajo infantil son la serie de 
perjuicios para el desarrollo y la integridad moral y física de los niños que éste acarrea, el diagnóstico no cuestiona cuál es la responsabilidad de las empresas. Además, hemos podido constatar durante las últimas décadas que el problema no se ha resuelto con un mero despliegue de políticas y programas de transferencias económicas condicionadas, ni con la puesta en marcha de "cualquier tipo de apoyo que permita desincentivar el trabajo infantil" (SEDESOL-UNICEF 2006:45).

Cuando uno lee que una de las principales estrategias del PAJA para lidiar con el trabajo infantil es realizar una "categorización por tamaño y tipo" de las familias en las cuales se presenta, para "ubicar mejor la condición de los niños" respecto a éste (SEDESOL-UNICEF 2006:50), difícilmente se puede desechar la idea de que detrás de esta perspectiva existe una cierta tendencia a encontrar un sujeto, accesible y lábil, en el cual puedan ser focalizados todos los síntomas del problema y sobre el cual se pueda actuar con cierta eficacia y prontitud. Y qué mejor que el padre, la madre y el niño indígena y campesino, cuyas carencias económicas, costumbres inexplicables y analfabetismo fácilmente podrían justificar su situación y 'preferencia' por el trabajo infantil. $\dot{\imath} \bigcirc$ con qué intención entonces se declara que "en el $46 \%$ de las familias que cuentan con parte o la totalidad de niñas y niños trabajando, los padres iniciaron como jornaleros agrícolas migrantes al igual que sus hijos, entre los 6 y 14 años"? (SEDESOLUNICEF 2006:42). Porque a mi juicio lo único que esto demuestra es que el nivel de marginación, pobreza y falta de oportunidades no ha mejorado en el transcurso de varias generaciones.

Mientras uno va recorriendo las páginas del Diagnóstico le va quedando la ligera sospecha de que lo que en cierta medida se busca hacer con esta alusión es establecer un vínculo casi 'natural' entre la condición jornalera de los padres y la situación laboral de los niños, cuando el hecho digno de analizar y explicar es que éstos no solamente trabajan a la par de sus padres, sino que están dando cuantiosos beneficios a las compañías agrícolas. Como si la duración de las extenuantes jornadas, el mísero pago y el hacinamiento que los niños padecen en los campos jornaleros fueran culpa o decisión de los padres, o consecuencia de una suerte de legado o herencia familiar de la que a la familia le ha sido imposible escapar. Pero nada se dice en este documento sobre las condiciones inhumanas de vivienda y trabajo que estas 
familias deben soportar para poder obtener los ingresos que en sus comunidades ya les prácticamente imposible ganar.

¿Qué motivación existe detrás de la aseveración de que "entre las familias de 3 a 6 miembros existe una tendencia respecto al trabajo infantil"? (SEDESOL-UNICEF 2006:52), siendo que el término "tendencia" es sinónimo de propensión e inclinación. ¿Es un error de sintaxis o un síntoma de la errada comprensión que sobre el fenómeno en cuestión presenta dicha institución?

¿Es el hecho de que para el $29 \%$ de estas familias la aportación del trabajo infantil pueda llegar a representar la tercera parte del ingreso familiar una muestra de que los padres se benefician gozos de la explotación de sus hijos? Sería interesante que se ofreciera en el Diagnóstico alguna explicación sobre ello o del por qué reiteradamente se presentan este tipo de datos y cifras. Y no estaría por demás que también se le explicara al lector por qué las 94 páginas que conforman el último esfuerzo de la SEDESOL por entender "la condición social de las niñas y niños migrantes internos, hijos de jornaleros agrícolas" se centran casi exclusivamente en presentar tipos, semblanzas, características, perfiles socio-demográficos, datos, cifras, gráficas y estadísticas sobre las familias y los niños campesinos migrantes; y no sobre el papel que juegan las empresas agrícolas, las grandes transnacionales, los gobiernos municipales, los empresarios, los políticos y la sociedad civil en la perpetuación de la explotación y la migración infantil. ¿̇Es solamente falta de voluntad política o acaso podemos pensar que existe una intención de no hacer demasiado evidente la implicación de estos actores para no afectar sus intereses?

Ahora bien, en ningún punto de este Diagnóstico se ofrece al lector una aclaración sobre qué es lo que se está considerando como "trabajo infantil", ni se hace una distinción entre lo que varias ONG's y organismos internacionales -como la OIT (2002)- han diferenciado como "trabajo" y "explotación" infantil o child work y child labor. Tampoco se hace una referencia explícita a los niños jornaleros como sujetos del análisis, a pesar de que el documento se centra en ellos y sus problemáticas, y sólo se les menciona como "hijos e hijas de los jornaleros migrantes".

Cuando por fin a la mitad del texto se establece una tímida relación entre las condiciones de precariedad económica y el trabajo infantil al decir que "en términos generales, la situación de las familias y de sus integrantes se muestra más aguda en los 
casos de aquellas en las que se da el trabajo infantil por parte de todos o de alguno de IOs niños y niñas" (SEDESOL-UNICEF 2006:56), uno se pregunta, no sin cierta desazón, por qué entonces todo el discurso de la institución gira en torno a "desincentivar" el trabajo infantil si más bien éste responde a las pauperizadas condiciones de vida y de salarios a las que están sometidos los jornaleros. Aún en los desatinados casos en los que se podría "culpar" a los padres por incluir a los niños en las labores jornaleras, a sabiendas de que no recibirán un pago extra por su trabajo, una explicación podría estar en que los padres deciden incorporarlos de todos modos porque el trabajo familiar o grupal permite maximizar los magros ingresos que se obtienen del trabajo a destajo (ver Sánchez 2001 y 2006). Asimismo, investigaciones realizadas en Chile señalan que el trabajo infantil es una respuesta coyuntural a situaciones de "emergencia" económica. Sin embargo, dado que la precariedad parece "constituir la norma más que la excepción", el trabajo infantil suele persistir a lo largo de varias generaciones (Maureira 2002:116).

Como bien demuestran Sánchez (2006) y Lomnitz (1974) en sus estudios, las estrategias productivas de las familias se definen tanto por las necesidades de consumo que éstas tienen según su tamaño y composición; como por las características generales del proceso económico regional e incluso global, que se manifiesta a través del desarrollo y la competencia de diversos sectores productivos, que son los que determinan las tendencias del mercado de trabajo, el volumen de la producción y el tipo de mano de obra que se requerirá (Maureira 2002:117).

\section{La naturalización del trabajo infantil}

No sólo las instituciones gubernamentales difunden discursos aberrantes y distorsionados. La British American Tobacco' de México distribuye en sus campos tabacaleros, donde cada temporada se emplean miles de niños Huicholes, Coras, Tepehuanos y Mexicaneros, un folleto que ha producido en el marco de su programa para prevenir la mano de obra infantil -ambos llamados "Florece"- donde manifiesta la intención de lograr una "concientización familiar [para] buscar un cambio cultural para

9http://www.batmexico.com.mx/OneWeb/sites/BAT_5NNARK.nsf/vwPagesWebLive/07A07E40CFB57573C 125 731300603CA9? opendocument\&SID=\&DTC $=$ 
erradicar esta práctica ancestral del trabajo de menores" (citado en Manzanos 2002:17). Nuevamente encontramos subyacente el prejuicio de que el origen de la explotación infantil está en la "cultura" y las "costumbres ancestrales" de las familias indígenas, que son vistas como atrasadas, ignorantes e incivilizadas. Lejos de ser un discurso inofensivo, estas palabras denotan una intención prejuiciosa de responsabilizar a la cultura indígena por los males que sufren los niños, eximiendo desde luego, a las compañías de toda responsabilidad. Lo que por supuesto no se menciona en este folleto es que las cuatro empresas tabacaleras transnacionales que firman el documento están obteniendo cuantiosas ganancias gracias a las ventajas que proporciona el trabajo infantil en un país como México, que resulta ser mucho más tolerante a este tipo de explotación que sus propias naciones "primermundistas".

Pero la explotación de los niños indígenas parece no ser un problema cuando se celebran a bombo y platillo los programas de voluntariado que la British American Tobacco promueve a través de su página Web, sin explicar siquiera si éstos se implementan en los municipios donde la compañía tiene sus plantíos tabacaleros, o si se trata en cambio de los lugares de origen de los migrantes. En esta página de Internet, la BAT muestra un video ${ }^{10}$ que no se distingue en nada de otras cápsulas sentimentalistas mostradas por bancos que encabezan programas de donaciones para "mejorar la calidad de la educación", asociaciones asistencialistas, o decenas de otras compañías como Danone, Coca-Cola o Bonafont que promueven campañas de supuesto beneficencia social sin aclararle al público cuán eficientes son los donativos para deducir impuestos o introducir sus productos en nuevos mercados. En él se muestra, sobre un fondo musical que pretende ser conmovedor, una serie de imágenes donde aparecen las ya mil veces vistas hileras de niños esperando su turno para recibir un juguete, una despensa o una cobija que, curiosamente, no fueron donados por la administración de la empresa, sino por sus trabajadores, quienes las pagaron con sus propios sueldos ${ }^{11}$.

La fórmula de la empresa es promover "la participación del personal en programas que beneficien a la comunidad" a través de "brigadas de reforestación, restauración de espacios públicos como parques, playas y escuelas, donación de

\footnotetext{
10www.batmexico.com.mx/OneWeb/sites/BAT_5NNARK.nsf/vwPagesWebLive/DA31D73EB472D9F7C 1257313 $00617 F 6 C$ ? opendocument\&SID=\&DTC=

11 Información proporcionada por la empresa en su página web.
} 
medicinas y ropa a instituciones necesitadas, capacitación a jóvenes y apoyo a comunidades rurales"12. Es decir, intervenir voluntariosamente en un conjunto de localidades y poblaciones que nada tienen que ver con quienes constituyen la principal fuente de trabajo de la empresa. En ningún momento se especifica si alguna de esas acciones beneficiaron a las comunidades de donde provienen los miles de niños indígenas que año con año son empleados, de manera ilegal, por la compañía para actividades como corte y ensarte de las hojas de tabaco. No obstante, se tiene buen cuidado de mencionar que a través de estas "variadas iniciativas en todo el país", se ha logrado beneficiar a 10,000 personas mediante 69 proyectos en un solo año que le han valido a esta 'caritativa' empresa dos premios del Centro Mexicano para la Filantropía (CEMEFI) en el ramo de las Mejores prácticas de Responsabilidad Social Empresarial.

Parecería ser la panacea, si no fuera por lo fútil que nos resulta ver una vez más la típica imagen del niño bien peinado y vestido para la ocasión, sosteniendo entre las manos un pandero que le acaba de ser obsequiado por un tipo que, sonriendo, le da palmaditas en la espala. Hubiera sido provechoso que junto con todos los datos que la empresa presenta, sobre el número de cobijas entregadas y los "miles de beneficiados", ésta explicara también de qué le serviría un pandero a un niño cuyas primeras necesidades son la alimentación y la vivienda, o por qué entre todas las imágenes editadas en este video ninguna muestra los campos jornaleros ni las condiciones en las que viven las familias indígenas que con sus miserables sueldos contribuyen a la bonanza económica de la empresa.

La cuestión es que, como bien dijera Ivan Illich (1984b:50-52), "la incuestionable alegría de dar y los frutos del recibir deben ser tratados como dos cosas totalmente distintas". Un involucramiento emocionalmente superficial obscurece toda capacidad de reflexión sobre la naturaleza y los beneficios de la ayuda que se intenta dar. Esto solamente provoca que se nos escape por completo toda posibilidad de reflexionar sobre la intención de control y normalización que a veces hay detrás de nuestras políticas, o sobre el daño que muchas veces pueden provocar nuestras intenciones al pretender, aunque esto sea de "todo corazón", que todos tengan nuestras mismas formas de vida, y por supuesto, de consumo.

12 Ídem. 
En su excelente obra Celebration of Awareness, Illich hace un lúcido llamado a frenar lo que podríamos llamar la 'hipocresía de la caridad, sometiendo a revisión nuestras propias prácticas piadosas y tratar de comprender hasta qué punto las empleamos para paliar el dolor que produce un sistema "canceroso", y cuántas veces esperamos que esto sea suficiente para que el "organismo" inicie una "cura espontánea". Pero es mucho más posible, nos dice lllich, que el paliativo "vuelva adicto al paciente, y logre así, persuadirlo de querer buscar una cura radical" (1984b:55).

En la página Web de la British American Tobacco se hace mención del trabajo infantil sólo para afirmar que éste ha existido "históricamente" en México. No obstante, a la compañía no le resulta difícil deslindarse de este hecho aduciendo que son los "productores de tabaco" los que contratan con frecuencia a los jornaleros migrantes en ciertos estados y ella, simplemente, concentra la mayoría de sus operaciones agrícolas en dichas áreas.

Debemos reflexionar entonces, como asevera Manzanos (2002), acerca de cuáles son los conceptos y las prácticas sobre las que se asientan las llamadas "políticas de infancia' que tanto bien dicen buscar para la niñez trabajadora. ¿Por qué los discursos tanto de instituciones gubernamentales nacionales y ONG's internacionales insisten en señalar, una y otra vez, a los padres y las familias indígenas pobres como los mayores responsables de que los niños tengan que trabajar extensas jornadas bajo condiciones inhumanas? ¿Por qué se centran casi exclusivamente en sus supuestas costumbres, y no en las causas estructurales, políticas y económicas, que cada año empobrecen a miles de familias y las obligan a migrar en busca de trabajo? Es aquí donde habría de comenzar a buscar una solución al problema, y no en una voluntad de simplemente "donar", "desalentar" y "concienciar" a las familias jornaleras, como de hecho pretenden hacer el PAJA y la SEDESOL.

Aquellos que ofrecen asistencia y caridad deben pensar, antes que en sus necesidad de altruismo, en cuáles son las causas de que existan las carencias que ellos creen percibir, así como en los efectos sociopolíticos que lo que ellos llaman "ayuda" traerán más delante, pues como bien apunta lllich (1984b:57), "Los ricos y los poderosos pueden optar por no dar, pero los pobres difícilmente pueden negarse a aceptar". Entonces, el centro de la discusión no es cómo lograr reunir más recursos para los programas de transferencias económicas condicionadas o para los programas de 
beneficencia que tanto ansían ayudar a los "pobres niños jornaleros", sino entender y hacer visible por qué razón están siendo explotados y marginados.

Finalmente es importante añadir, a manera de cierre para este capítulo, que si he decidido elegir estos dos casos para mi análisis es no porque considere que son la única perspectiva o forma de trabajo que existe desde las políticas públicas, pero sí que representan una visión muy significativa e interesante, digna de discusión y análisis. Las políticas públicas y los programas institucionales, como cualquier otra forma de ejercicio del poder, contribuyen a la creación de sujetos específicos y es por ello que considero fundamental hacer una reflexión sobre el tipo de prácticas e ideas que a partir de estos programas se reproducen sobre la infancia indígena y la población jornalera. Se trata de una evidencia más que apoya mi argumento de que el sustento teórico y empírico de estas iniciativas debe estar basado en un reconocimiento real y efectivo de los niños como actores sociales plenos, capaces de agencia. De lo contrario continuaremos en una retórica que no produce avances materiales palpables ni argumentativos. 


\section{Capítulo 4}

\section{Nuevas posibilidades desde la antropología}

\section{Infancia y representatividad}

El estudio de la infancia ha tenido una mayor cabida en la antropología a partir de la década de los 80's. Como mencionábamos en la introducción, esto puede deberse en buena parte al creciente impacto que los problemas de la infancia están teniendo en un mundo cada vez más globalizado e interconectado. Pero también los debates de la antropología contemporánea y las aportaciones de los estudios feministas de las últimas décadas, así como los postulados sobre la representatividad, la autoría y la escritura etnográfica de autores como Geertz, Clifford y Marcus, figuran como responsables de este creciente interés y esta mayor visibilidad de la infancia en las ciencias sociales en general. Fue gracias a estas reflexiones teóricas que la antropología comenzó a abrir nuevos espacios para el análisis de la otredad, la alteridad, el diálogo y el encuentro etnográfico con sujetos que no habían sido objeto de interés antropológico.

Un ejemplo de las contribuciones de este tipo de reflexiones teóricas para el estudio de la infancia es el llamado de atención que Clifford Geertz (1989) hizo sobre el "ventrilocuismo antropológico", dado que también en las investigaciones con niños y sobre la infancia debemos poner atención para no solamente hablar de otra(s) forma(s) de vida, sino para intentar de hablar desde ella(s) (James 2007:265) o junto con ella(s). Hay una sutil pero muy importante diferencia entre estas dos formas de construir el conocimiento antropológico, y esto es quizás lo que los organismos internacionales, que en su mayoría promueven visiones homogéneas y universalistas de la infancia, no han notado.

Existe una diferencia fundamental entre simplemente presentar entrevistas o los testimonios de los niños (como sucede en el caso del PAJA analizado en el cap. 3) e intentar comprender su perspectiva como un fenómeno que en es en sí mismo múltiple 
y multivocálico, en tanto que en ella intervienen diversos procesos socio-culturales, relaciones de poder, mecanismos de aprendizaje, pautas de socialización y relaciones intersubjetivas. Debemos, por lo tanto, reconocer y enfrentar de manera adecuada las distintas posibilidades e implicaciones que esto conlleva.

La antropología de la infancia ha revelado que los niños representan una forma de otredad antes no vista, una otredad con respecto a los adultos y a un mundo adultocéntrico que los había hecho "conceptualmente extraños" (James 2007:262), e incluso irrelevantes para las disciplinas sociales. Pero el debate antropológico iniciado en la década de los 80's y que se extiende hasta hoy, ha demostrado que trabajar por una antropología de la infancia significa llevar hacia nuevos horizontes teóricos y nuevas posibilidades etnográficas los resultado del debate acerca de la relación investigador-informante, el punto de vista del sujeto y el papel activo que los actores sociales juegan en el proceso de construcción y escritura de la investigación antropológica.

A raíz de la mayor visibilidad de la infancia y la niñez en la arena global, organismos internacionales encabezados por la UNICEF y la OIT, han puesto un énfasis cada vez mayor en cuestiones como la inclusión, la participación y los derechos de la infancia. Como postula James (2007:261), desde la proclamación de la Convención Universal de los Derechos del Niño en 1989 "escuchar las voces de los niños se ha convertido en un poderoso y persuasivo mantra para activistas y para quienes construyen las políticas públicas alrededor del mundo". Esto en sí mismo es un avance positivo, no obstante, la antropología ha hecho notar que si bien es fundamental un reconocimiento cada vez mayor de la importancia de los niños como actores de su sociedad y sujetos que deben ser escuchados, con frecuencia los postulados y las concepciones de este tipo de instituciones o de ciertas ONG implicadas en la atención de la infancia en el mundo, se dan desde un marco analítico demasiado universalista, homogéneo y prominentemente basado en concepciones occidentales sobre la niñez. Se habla de la infancia en el mundo como si ésta no fuera tan multifacética y compleja como lo es la propia diversidad cultural.

Con frecuencia estos organismos adoptan ideas y postulados unilineales que, al ser el fundamento de sus discursos, prácticas y metodologías, dan como resultado nociones homogéneas sobre la infancia, muchas veces sustentadas en el paradigma 
de la igualdad, pero que no necesariamente constituyen un avance para la construcción de contextos y condiciones más equitativas para los niños en distintas regiones del mundo. Tal es el caso del nuevo postulado sobre la "participación" infantil que, reconociendo a los niños como sujetos, insta a escucharlos y a registrar su voz como si en ella se encontrase una especie de verdad "más auténtica" o noproblemática.

Ciertamente, como apunta la Carta para los Derechos del Niño, las voces de los niños deben ser prominentes en la exploración de lo que sucede en sus vidas, debemos entenderlos y aproximarnos a ellos como sujetos cognoscentes. No obstante, muchas veces este tipo de postulados favorecen una visión en la que parece que en las palabras que los niños yacen encapsuladas "la inocencia y la autenticidad de la condición humana, que rápidamente se pierde en el mundo adulto" (James 2007:261). Es como si los niños fueran inocentes e inmaculados, como si tuvieran una bondad natural y una claridad de visión que debe ser idolatrada y alabada como la fuente de todo lo que es bueno por naturaleza en el género humano y que, sobre todo, debe ser protegido y salvaguardado.

Como hemos visto en los capítulos anteriores, este tipo de discursos que intentan normalizar una visión particular sobre una realidad empírica mucho más compleja y diversa, con frecuencia llevan implícita una intención de controlar y definir las categorías en consonancia con su propia visión de las cosas. Nuevamente se trata de un tipo de gubernamentalidad a la que los niños de ninguna manera escapan. Es así que "recitadas ahora por políticos y activistas, las voces de los niños se han convertido en un símbolo del compromiso moderno por los valores de la libertad, la democracia y el cuidado" (James 2007:261). En el nombre de los niños y la infancia se han trazado políticas, legislaciones e iniciativas que muchas veces nos dicen más acerca de las agendas políticas de las instituciones y organismos que las promueven y de una cada vez más globalizada "economía política de la infancia" (Schepper-Hughes \& Sargent 1998), que sobre los niños mismos.

Un ejemplo muy ilustrativo de esto es el caso estudiado por Rosen (2007) de los niños soldado en África y la construcción de una política transnacional de la edad que busca acoplar el concepto de infancia a la legislación internacional en materia de conflictos armados. A través de esta "política de la edad" distintos actores 
internacionales, locales y regionales -como gobiernos nacionales, grupos humanitarios y la propia ONU-, manipulan el uso de las categorías de edad para promover sus posturas ideológicas, legales y políticas particulares, haciendo que una agenda política específica termine siendo concebida y aceptada como una norma cultural preexistente. Esto no sólo lleva a ignorar definiciones culturales previas de la infancia y la niñez, o la complejidad y la diversidad social de que la antropología ha dado cuenta durante décadas, sino a construir la retórica y el pensamiento sobre la infancia sobre bases normativas, políticas y legales más que empíricas.

El principal problema detectado por Rosen (2007) es por lo tanto que la definición humanitaria de la infancia y su expresión en la ley internacional más que estar fundamentada en la experiencia empírica y en nociones trans-culturales, está imbuida en la política transnacional, lo cual la hace extremadamente limitada y provoca que no sea un instrumento efectivo para encontrar diversas soluciones a la serie de problemas que los organismos humanitarios mismos han identificado y están tratando de resolver.

Resulta entonces que, basadas en el compromiso que las instituciones han hecho con los valores supremos de la ilustración, como la libertad y la igualdad, éstas se han atribuido las facultades de controlar y normar también el mundo infantil. Basta con revisar el Artículo 12 de la Declaración Universal de los Derechos del Niño, donde se habla del "interés superior del niño", a quien, después de haberle otorgado el derecho de hablar, se le encapsula en una sola categoría universal e indiferenciada, logrando nuevamente naturalizar, invisibilizar y esencializar a la infancia (James 2007:265).

Aunque lo común es que a los niños no se les pregunta por su opinión y su punto de vista, cuando esto se llega a hacer pocas veces sus ideas y perspectivas son realmente tomadas en serio y son aplicadas. Por ello, la antropología ha llamado la atención acerca de que lo substancial no es sencillamente dejar hablara a los niños, sino reconocer y explorar a profundidad la contribución que sus perspectivas hacen para nuestro entendimiento y la teorización del mundo social (James 2007:262).

Es justamente por esto que la antropología de la infancia está tan interesada y comprometida con un debate acerca de la autenticidad de las voces, la polifonía y la traducción, la mediación y la interpretación antropológica, pues sólo explorando estas cuestiones podremos entender qué "voz" es la que habla a través de los niños y qué es 
lo que realmente se está transmitiendo cuando se escribe un texto antropológico sobre la infancia, además de entender cómo ésta se produce y reproduce. Efectivamente no basta con sólo escuchar a los niños, debemos también preocuparnos por cuestiones epistemológicas mucho más profundas y complejas, como la reflexión acerca del modo en que es construido y experimentado el espacio en el cual y a partir del cual los niños se posicionan y se expresan; o bien cómo se puede rastrear y comprender el sentido de sus palabras, cómo se pueden representar adecuadamente sus intereses, quién deberá representar e interpretar sus voces y cómo y por qué, o qué función deben jugar estas voces en las investigaciones antropológicas al tiempo que nos hacemos concientes de las implicaciones que las relaciones de poder tienen en la construcción de las mismas.

No pensar sobre todo esto o pasarlo por alto sería "orientalizar" (Said 1990) a los niños. Siguiendo los postulados de Edward Said, podemos decir que la concepción universalista y etnocentrista en la que están basadas las políticas y los discursos de las organismos internacionales que trabajan con la infancia, constituyen una narrativa "orientalizante" que busca instaurar un punto de vista hegemónico, cultural e ideológico sobre la infancia, definiéndola en base a características superficiales que optan por naturalizarla, esencializarla y delinearla en base a una otredad definida con respecto al mundo adulto.

Este punto de vista se sustenta en una serie de instituciones que a su vez tienen vocabularios, doctrinas, normas, valores e incluso declaraciones de carácter universal que pretenden definir, determinar y ejercer una autoridad sobre el conocimiento y el trabajo con la niñez, desplegando una suerte de "colonialismo" sobre la infancia que termina por entenderla y definirla como fenómeno discreto y unilineal enmarcado en una concepción progresiva del desarrollo humano, donde un estado de "inmadurez" es superado para alcanzar la plenitud del adulto. Esto, discretamente sugiere la idea de que el mundo está dividido en dos ámbitos separadas: el de los niños, donde las personas son mayormente frágiles, inacabadas, inocentes y pueriles, y el de los adultos, al cual se accede luego de que el individuo ha madurado y se ha convertido en un sujeto responsable, dueño de sí, autónomo y autosuficiente, pero también autoregulado y auto-vigilado. Una visión que, como hemos visto en capítulos anteriores, concuerda muy bien con la idea que sobre el individuo promueven el capitalismo y las 
instituciones que tienen su fundamento en el paradigma de la modernidad y el progreso.

La existencia y la reproducción institucional de estas ideas, que acaso buscan convertirse en un control normativo, es posible sólo gracias al establecimiento de una serie de pautas y principios para la acción y la intervención a las que distintos países deben adherirse bajo el supuesto de hacer primar el "interés superior del niño". No obstante, esta idea debe ser discutida y sobre todo matizada, en tanto que pasa por alto el hecho fundamental de que si no hay una sola forma de ser niño, tampoco una sola forma de entender a la infancia $y$, por ende, no hay una única vía para comprender sus experiencias y sus problemáticas cotidianas. En realidad esto nos habla más de una voluntad por disciplinar, manipular e incorporar a los individuos a un mundo en el que el individuo está definido en base a determinadas ideas, enmarcado por ciertas reglas y controlado por instituciones específicas. Es por esto que, el conocer los pormenores de las instituciones dedicadas a la atención de la infancia, y sobre todo de aquellas destinadas a la infancia "pobre o marginada", nos será más útil para entender sobre qué bases está fundamentado el control y la gubernamentalidad posmodernas, que para entender a los niños y a la infancia en sí misma.

Al igual que postula Said para el Orientalismo, con este tipo de prácticas de saber se pretende, más que conocer, crear un sujeto manejable y disciplinable en el que los instrumentos del poder y el conocimiento puedan ser aplicados. Un claro ejemplo serían los documentos analizados en el capítulo 3, donde los padres indígenas, las familias jornaleras y los niños trabajadores son revisados, definidos y pensados una y otra vez como víctimas de sí mismos, como sujetos subdesarrollados, incapaces de generar un cambio favorable en sus paupérrimas condiciones de vida, tampoco de distinguir entre lo que es "bueno" y lo que es pernicioso para sus hijos. Son de hecho "infantilizados", una práctica común de la sujeción colonial, para poder hacer de ellos sujetos dóciles, que ilustran bien el lado perfectible del Desarrollo y sobre los cuales debe aplicarse todo el aparato de las políticas públicas y los planes nacionales e internacionales de desarrollo.

Con los niños jornaleros esto resulta todavía más fácil, pues la niñez ha sido tradicionalmente construida como la representación de la "pureza" y el precioso "futuro" de la nación. En la sociedad moderna los niños representan actores políticos 
incompletos, pero aun más, la infancia "simboliza una inocencia esencial que trasciende la política y la cultura" (Mankekar 1997:52) para perderse en el terreno de la naturaleza, de lo inmaculado y de lo que no ha sido corrompido, pero también de lo que es irracional y voluble. Por ello, los niños jornaleros, siendo indígenas, pobres, analfabetos y migrantes, son los sujetos idóneos para encarnar la sinécdoque de esta "frágil pureza", la pureza y la inocencia de la nación, sus valores y su moral, que es fácilmente puesta en peligro, incluso por su propia cultura y sus propios padres y que es "nuestra" legítima responsabilidad proteger.

Resulta entonces crucial comprender y tener presente que el conocimiento producido desde estas instancias no es otra cosa que una representación más, en este caso sobre los niños y que, al igual que cualquier otra, debe ser contextualizada y discutida. Es indispensable tener en mente, como postula Said (1990:40-43), que estas representaciones se apoyan en tradiciones, instituciones, creencias, convenciones y códigos de inteligibilidad que les proporcionan una gran coherencia interna y un conjunto muy bien articulado de relaciones con la cultura dominante que las envuelve y sustenta. ¿ Cuáles son entonces las ideologías y los discursos que le dan al Estado la legitimidad para definir, decidir e intervenir a favor de los niños jornaleros, para decidir lo que es "bueno" y "malo" para ellos? ¿Por qué es tan fácil que los niños sean apropiados por la autoridad y el discurso nacional? ¿ Qué lecciones nos deja un análisis del papel del Estado en la construcción de la infancia?

Un interesante ejercicio teórico y metodológico para explorar nuevas posibilidades de experimentar e intentar trascender estas implicaciones sería una antropología como la propuesta por Charlotte Hardman (1973), donde los niños son sus propios informantes acerca del mundo social y éstos juegan un papel crucial para la construcción y la conducción de la investigación. Aunque esta propuesta podría realmente constituir una diferencia sólo si se haya asentada en una reflexión sobre qué es exactamente lo que la inclusión de las voces de los niños busca lograr y de hecho logra en la investigación antropológica, pues debemos ante todo reconocer sus intervenciones como discursos construidos, cuya pertinencia y "autenticidad" debe ser cuestionada, no asumida (James 2007:265).

De manera que debemos matizar y encontrar un punto intermedio entre las aseveraciones universalistas sobre el bienestar y las vidas de los niños hechas por 
algunos organismos internacionales, que pasan por alto la necesidad de un cuidadoso y profundo reconocimiento del contexto cultural en el que estos niños se desenvuelven; y la idea contraria de que las voces de los niños, por el mismo motivo, serían imposibles de representar. El objetivo es crear un justo equilibrio entre la inconmensurable variabilidad de sus experiencias y sus formas de ser niños y de vivir su infancia, y la universalización que se puede y debe hacer algunas veces para poder hablar de una antropología de la infancia que haga aportaciones para el conocimiento de los niños de todas las sociedades (James 2007:266).

\section{Economía y cultura política de la infancia}

Numerosos autoras han reconocido la importancia de la teoría feminista para el desarrollo crítico de la antropología de la infancia y han usado este enfoque para el desarrollo de nuevas orientaciones analíticas y teóricas en sus propias investigaciones (Moscoso 2008, Schepper-Hughes \& Sargent 1998, Mankekar 1997, James 2007). Fundamentalmente, lo que se propone a través de este acercamiento a la crítica feminista es que sus cuestionamientos sobre el poder, la posmodernidad y la construcción del saber, las subjetividades y el Estado-Nación contemporáneo contribuyen de manera muy significativa al debate epistemológico sobre la infancia en tanto que hacen patentes los distintos posicionamientos y agendas desde los cuales la infancia ha sido construida de acuerdo a las grandes narrativas de la Nación y sin cuya comprensión estaremos fallando en la tarea de entender cómo se han ido construyendo los "múltiples posicionamientos de los niños en el mundo contemporáneo" y cómo éstos han sido relegados a los márgenes del conocimiento y de los discursos hegemónicos (Mankekar 1997:30,51).

Estudiar a la infancia recuperando las aportaciones de la crítica feminista nos permitirá avanzar hacia el entendimiento de las profundas relaciones que la concepción de la niñez guarda con otras nociones de orden capital para el análisis de las sociedades contemporáneas, permitiéndonos comprender cómo los "regimenes modernistas de poder y conocimiento median la posición de los niños al interior de la nación" entremezclando e inscribiendo en la construcción de la infancia discursos sobre clase, comunidad, nacionalismo, cultura y naturaleza, poder, pobreza, moral, 
sexualidad, inocencia y control. Lo relevante es entonces en qué manera estos discursos están implicados no sólo en la construcción y la inscripción de la infancia, sino en qué manera moldean nuestro entendimiento de la subjetividad de los niños (Mankekar 1997:51).

El reto de la antropología de la infancia es, por lo tanto, recuperar los postulados críticos que se han hecho y se están haciendo desde otras áreas de la antropología sobre la otredad, la desigualdad, la exclusión, la resistencia y la representatividad, entre otras cuestiones, para lograr un conocimiento profundo de la construcción de la infancia como categoría cultural imbuida en complejas realidades sociopolíticas y económicas, de la participación de los niños en la creación de nuevos mundos sociales a través de sus vidas cotidianas, y de lo que la utilización discursiva de la infancia puede revelarnos acerca de las nuevas formas de crear identidades, comunidades, instituciones, necesidades, modernidades y naciones. De igual manera, la antropología de la infancia tiene mucho que devolver a otras áreas de la antropología y de las ciencias sociales porque nos muestra que, contrario a lo que se pensaba hace no mucho tiempo, hoy sabemos que las identidades nacionales y los contextos políticos permean y afectan profundamente las vidas y las conciencias de los niños, así como su moralidad y sus formas de ser y pensar acerca del mundo (Schepper-Hughes \& Sargent 1998:2). Estudiar y trabajar con la infancia es, entonces, devolvernos a nosotros mismos una mirada crítica sobre nuestras sociedades y nuestra forma de entenderlas y estudiarlas para permitirnos develar nuevos proyectos sociales de poder, conocimiento, de Nación y de modernidad.

Inclinarnos simplemente por una condena piadosa de la explotación laboral de la infancia, como la que suelen proclamar diversas ONG, instituciones humanitarias y organismos gubernamentales e internacionales como SEDESOL y UNICEF puede no sólo ser ineficaz, sino estar contribuyendo a la invisibilización y el obscurecimiento de las causas que están en el fondo de la problemática, como un aparato legal disfuncional y negligente, dispositivos e incentivos económicos que favorecen este tipo de patrones laborales explotadores, políticos y funcionarios corruptos que permiten y solapan esta situación y, desde luego, una sociedad fundada en profundas desigualdades políticas y económicas. 
Por otra parte, querer simplemente sustituir el trabajo infantil por la escolarización como se suele proponer, sin discutir o polemizar esta medida, puede incluso servir para ocultar la creación de una arena para la transferencia y el adoctrinamiento en los valores de la sociedad urbana, mestiza, occidental, para la creación de sujetos compatibles con sus formas de producción, sus estilos de vida y sus mecanismos de reproducción social; para disciplinar política, moral y éticamente a las poblaciones subdesarrolladas y a la futura mano de obra lábil, competitiva, móvil y desterrada que la economía global requiere. La solución no es, de ninguna manera, unilineal.

El problema con el discurso sobre el derecho de los niños a no trabajar y a recibir educación, por ejemplo, es que, como sucede con el discurso sobre los Derechos Humanos en general, se "hace de la moralidad política el resultado de un imperativo moral incondicional" (Schepper-Hughes \& Sargent 1998:10) e incuestionable, evitando abordar las implicaciones que en ello tienen los discursos políticos, la agenda nacionalista, o la importancia de una reflexión sobre una realidad empírica concreta, un contexto regional y un compromiso social y económico específico. Se ignora por completo la construcción social -y por ende la complejidad política- de categorías como la de infancia, indígena, pobreza, jornalero, migrante, etc., y se tiende a naturalizarlas, esencializarlas y a darles un carácter universal y estático.

Parafraseando a Schepper-Hughes \& Sargent (1998:10) podemos decir que todo esto nos muestra hasta qué punto la propagación del "mito de la infancia", a través de decenas de discursos y programas sobre los derechos y la protección y la "salvación" de la infancia, ha contribuido a que en nuestra sociedad adultocéntrica se desplace a los niños a los márgenes de la cultura postindustrial y consumista del capitalismo tardío; y cómo esto puede ser el resultado de la pérdida en las sociedades post-agrícolas y post-industriales de los países del Norte, de los roles productivos que los niños solían tener.

En los países ricos y en la sociedad posfordista hoy en día los niños son vistos más como consumidores que como productores o aprendices de algún oficio, por lo tanto, nos dicen Schepper-Hughes \& Sargent (1998:11), han sido relegados al estatus de "receptores del bienestar familiar, compadecidos y conmiserados tanto como valorados y protegidos". Esta visión contemporánea sobre la infancia, característica y complementaria del pensamiento político y económico de la época, ha logrado 
retratar a los niños, y sobre todo a los niños de otras culturas y estratos sociales, mayormente como un peligro y una amenaza para el orden social y la seguridad personal y económica de los adultos.

Un ejemplo de ello es el hecho de que el reclamo más frecuente de los sindicatos de trabajadores adultos en contra del trabajo infantil es que éste contribuye a vulnerar sus intereses como trabajadores y a depreciar sus salarios. No son la explotación a la que los niños y ellos mismos están sujetos cotidianamente ni las estructuras de desigualdad que sustentan estos regimenes laborales lo que les preocupa, sino el hecho de que los niños estén dispuestos a aceptar trabajar en peores condiciones que ellos y por lo tanto, ponen en peligro su trabajo y su salario.

De manera que al haber obtenido derechos que los protegen del trabajo familiar y forzado o el aprendizaje temprano de un oficio, los niños modernos pueden haber ganado o 'recuperado' su infancia, pero han perdido considerablemente el estatus y el poder de que gozaban en sociedades tradicionales, donde su trabajo, explotador o no, era valuado socialmente por su contribución a la reproducción familiar y en muchas de las cuales sus opiniones eran escuchadas y respetadas como la voz de actores sociales auténticos (Schepper-Hughes \& Sargent 1998:11), como ejemplifica el trabajo de Pamela Reynolds entre los Tonga de Zimbabwe (1991).

En las sociedades posfordistas sucede que mientras el trabajo de los niños ha tendido a desaparecer y su importancia económica es ya casi nula -al menos en algunos estratos sociales-, el "valor instrumental" de la infancia ha sido reemplazado por su "valor expresivo", y ahora los niños son apreciados por su valor psicológico. Esto ha estado acompañado por un proceso concomitante en el que el creciente individualismo y la prevalencia del discurso de los derechos humanos han otorgado a los niños una autonomía prematura (Schepper-Hughes \& Sargent 1998:12). Para ilustrar esta situación cabe mencionar el caso de los "parachute children" de origen coreano, estudiado por Faulstich Orellana et al (2001 576-581), que son enviados por sus familias a los Estados Unidos para estudiar y obtener la nacionalidad americana y quienes muchas veces terminan encarnando -no sin complejas consecuencias- las aspiraciones familiares de lograr la movilidad social mediante estrategias transnacionales y en una esfera económica global reordenada. 
Podríamos concluir este apartado diciendo que trabajar con la infancia contemporánea y sus complejidades es enfrentar las contradicciones propias de la modernidad, es poner nuestra mirada en los márgenes de los discursos hegemónicos, en los márgenes de las prácticas políticas contemporáneas, de los proyectos de construcción del poder y el conocimiento, de la explotación económica globalizada, de la construcción del otro aquí y allá, de las nuevas formas de control y disciplinamiento, de las grandes narrativas de la modernidad, del flujo y de la reinvención de las identidades transnacionales y post-nacionales. Dedicar una mirada analítica al problema de la infancia es, en suma, abordar desde nuevas posibilidades teóricas y metodológicas la siempre vigente discusión sobre la construcción del poder y la hegemonía, la otredad y la subalternidad. 


\section{Capítulo 5}

\section{Propuesta doctoral}

Para el doctorado es mi intención profundizar y perfeccionar los postulados teóricos que ya se han planteado en esta tesina de modo que pueda dar continuidad a este trabajo, pero sobre todo para construir una base teórica lo suficientemente sólida como para permitirme realizar un estudio comparativo sobre las relaciones entre la explotación laboral y la construcción de la infancia en el capitalismo tardío en la India y México.

Por lo tanto, planteo un primer periodo de trabajo de campo en distintos campos jornaleros de los estados de Morelos y Michoacán, donde cuento ya con apoyo para el ingreso y el trabajo con la comunidad jornalera y, si se presenta la oportunidad, en otros campamentos del Norte del país, como Sinaloa o Baja California.

Los métodos de campo a desarrollar habrán de adaptarse desde lvego a las condiciones físicas y materiales de cada campamento, así como al número de niños que en éstos encuentre y a su disponibilidad de horarios de acuerdo a sus jornadas de trabajo. No obstante, considero que cuento ya con una sólida base metodológica que he puesto en práctica con anterioridad y que ha probado ser efectiva y muy interesante para el trabajo antropológico con niños.

Esta consiste principalmente en la creación y puesta en práctica de ejercicios lúdico-creativos basados en las posibilidades comunicativas del arte, el juego, el teatro y los medios audiovisuales para aprovechar el uso de estas herramientas tanto como sus resultados como formas alternativas de expresión y representación etnográfica. Este tipo de ejercicios y métodos será por supuesto complementado y enriquecido con los métodos tradicionales de la antropología, como son la observación participante, el diario de campo, la historia de vida, las entrevistas a profundidad y posiblemente también la aplicación de encuestas y la creación de mapas, entre otros.

Como he mencionado ya con anterioridad, la investigación antropológica con niños no es cuestión de sencillamente dar a los niños las herramientas o simplemente 
dejar la investigación en sus manos. Esto sería mucho más que irresponsable y contraproducente. Por el contrario, trabajar junto con los niños intentando una auténtica colaboración y una co-autoría significa saber aprovechar las posibilidades que nos brindan las interacciones entre los niños y la investigadora y de los niños entre sí. Es decir que se debe ser capaz de promover un diálogo entre los distintos actores sociales en el que uno pueda ser tanto un "detonador" de las preguntas de investigación -y sus respectivas respuestas-, como un observador de las interacciones entre los sujetos-actores de la investigación, en tanto que el momento y el escenario mismo de la producción de las respuestas, los testimonios y las intervenciones de los niños constituyen momentos etnográficos que deben ser registrados y teorizados.

Pero incorporar a los niños como sujetos activos de la investigación e intentar poner en sus manos el desarrollo y los alcances de la misma significa también saber interpretar su voluntad, sus motivaciones y su agencia, la naturaleza socialmente construida de sus testimonios y sus puntos de vista, así como poder comprender la complejidad de sus subjetividades, su creatividad y sus experiencias.

Puesto que el objetivo de este proyecto es generar una investigación que nazca de la intencionalidad, las experiencias y las reflexiones de los niños jornaleros pretendo utilizar lo que la antropóloga Rossana Podestá (2004, Podestá et al. 2002) ha llamado una metodología "detonadora", que retoma las herramientas básicas de la investigación etnográfica para convertirlas en auténticas posibilidades de diálogo intercultural entre el investigador y los niños, así como entre los propios niños. Esto, a través de una serie de preguntas que permiten desplazar al investigador como centro del conocimiento etnográfico y figura de poder, para así abrir un espacio donde los niños puedan cuestionarse a sí mismos y a sus compañeros acerca de sus vidas y problemáticas, asumiendo un papel reflexivo, de investigadores y narradores.

Empleando además distintas herramientas lúdicas se ofrecerá a los niños diversas posibilidades de representación y diálogo a través del arte, el juego, el teatro y la narrativa (gráfica, oral y escrita), que han probado ser sumamente eficaces en contextos interculturales y particularmente difíciles, como el de la migración y el trabajo infantil indígena (Quinteros 2005, Glockner 2008).

Finalmente, una vez reunido un vasto corpus de datos etnográficos y narrativas construidas por los propios niños (textos, testimonios, fotografías, audiovisuales, etc.), se 
hará un segundo ejercicio para "devolver" a los niños el material recopilado o trabajado hasta entonces con el fin de que ellos puedan trazar nuevas conclusiones sobre sus propios testimonios, documentos y reflexiones. El objetivo de este ejercicio será motivar la construcción de un diálogo reflexivo de los niños con sus propias ideas y creaciones testimoniales, así como trazar la ruta epistémica seguida por sus opiniones y narrativas. Esto, nuevamente, constituirá en sí mismo un momento "etnografiable" que nos permitirá entender más sobre la intencionalidad y la agenda detrás de los testimonios producidos.

Por supuesto no todo el trabajo de campo estará enfocado en los niños, de manera que la documentación bibliográfica, las entrevistas a otros actores sociales e instituciones involucrados con la infancia jornalera y/o trabajadora serán igualmente importantes.

\section{Algunos ejes para el estudio comparativo}

En 1996 la Organización No Gubernamental "Human Rights Watch" (1996) publicó un informe extensivo sobre el trabajo en India en el que se declara que este país asiático tiene el mayor número de menores trabajadores en el mundo, pues se calcula que la cifra total oscila entre los 60 y los 115 millones de niños. Por su parte UNICEF ha citado que el total puede contabilizarse entre los 75 y los 90 millones de niños (Human Rights Watch 1996:122). Cual sea la cifra exacta no es lo realmente importante, dada la enorme magnitud del problema. Lo preocupante es que el conocimiento que el gobierno indio ha producido sobre esta problemática es escaso y caduco, como demuestra el hecho de que éste continúa basándose en datos recolectados durante el Censo nacional de 1981 (Badiwala 1998:1) para la elaboración de sus programas y estadísticas. Incluso en eso, la situación de la información gubernamental sobre el trabajo infantil en India no es muy distinta a la de México.

Gracias al Censo de India antes mencionado se sabe que el $84.29 \%$ de los niños trabajadores en el área rural son empleados en tareas agrícolas, mientras que el 39.16\% de los niños trabajadores urbanos son empleados en labores como la manufactura, el procesamiento, los servicios y las reparaciones, la mayoría de los cuales trabajan en condiciones de esclavitud y/o para el pago de alguna deuda (Badiwala 1998:2). 
Haciendo una sucinta revisión del panorama del trabajo infantil en India, sea éste de carácter rural o urbano, podemos ver que es significativamente similar a México, y en particular al caso de los niños jornaleros migrantes, en tanto que el ingreso económico aportado por los niños a la economía familiar puede llegar a representar hasta la mitad o la tercera parte del ingreso total de la familia y, por lo tanto, es esencial para la supervivencia y la reproducción de la misma. En la India además, el panorama se torna acaso algo más complejo no sólo por la magnitud demográfica de la población de menores trabajadores, sino por la naturaleza de los problemas a los que éstos se enfrentan, como el trabajo en condiciones de esclavitud para el pago de una deuda familiar, la venta de menores para su empleo en trabajos insalubres y peligrosos, y la pertenencia a ciertas castas que obstaculizan o complican la asistencia de los niños a la escuela.

Por otra parte podemos decir que, al igual que en el caso mexicano, en la India la pobreza está íntimamente relacionada con el trabajo infantil y tiene mucho que ver con sus causas. Sin embargo, limitar nuestro análisis al factor de la pobreza sería no sólo buscar explicaciones unilineales y deterministas sino, como asevera Mankekar (1997:3435), sino despojar de toda agencia y voluntad a las personas que viven bajo estas duras condiciones económicas, haciéndola a ésta equivocadamente responsable por sus acciones. Por lo tanto, el análisis del trabajo infantil jornalero en México, así como el de la explotación infantil en India, requiere de perspectivas más complejas que sepan interpretar y conjugar las distintas realidades macro y micro sociales, políticas y económicas.

En el caso de la India, la existencia de castas que históricamente han sido relegadas a los estratos más bajos de la sociedad y a las cuales pertenecen la mayor parte de los niños trabajadores en algunas regiones, nos ofrece un rico e interesante panorama para la comparación con las etnias indígenas de México y los mecanismos de explotación y sometimiento a los que éstas se enfrentan en el marco de dinámicas macroeconómicas y políticas internacionales que trascienden los límites nacionales y se interconectan en la escala global.

De igual manera, un análisis sobre la conceptualización de estos menores trabajadores por parte de ONG, políticas públicas e instituciones gubernamentales en ambos países constituye una magnífica oportunidad para adentrarnos en el 
conocimiento de los mecanismos de construcción, posicionamiento y explotación de la niñez marginada y vulnerable en el marco de la construcción y legitimación de los estados Nacionales y en el contexto de una economía política internacional de la infancia.

Sumamente interesante sería, por ejemplo la oportunidad de comparar y contrastar las experiencias y los testimonios de los niños jornaleros en México con las de otros niños y niñas trabajadores del sur de India, donde los menores se organizaron para la creación del Sindicato de Niños y Niñas Trabajadores Bhima Sangha, que ha logrado el reconocimiento del gobierno estatal y que actualmente cuenta con más de 20 mil miembros, todos ellos menores. Este sindicato infantil trabaja dando asistencia a la niñez trabajadora y participando directamente en los programas de planificación de los gobiernos locales o panchayats. Han logrado además presionar a dichos gobiernos locales para que proporcionen a los niños la posibilidad de estudiar y trabajar a la vez, además de que han provocado un giro en la experiencia de la democracia a nivel local con la inclusión de niños y niñas en los propios comités de gobierno y dando, además, un lugar preponderante a la perspectiva de género.

A grandes rasgos la propuesta de continuación para el Doctorado se centra en la investigación, la comparación y el análisis de las condiciones de trabajo de los menores de origen rural en India y México para indagar sobre los vínculos que éstas tienen con los mecanismos de explotación característicos del capitalismo tardío y con la construcción de subjetividades en el posfordismo. Para que este último enfoque tenga una profundidad suficiente se plantea también la investigación, la comparación y el análisis de los discursos producidos en contextos nacionales e internacionales sobre la niñez vulnerable, manifestados y materializados principalmente a través de políticas públicas, planes de desarrollo, ONG, e instituciones gubernamentales y humanitarias, entre otros, con el fin de entender la vinculación de éstos con la construcción de grandes narrativas como las de nación, infancia, pobreza, agencia, modernidad y desarrollo.

\section{Capítulo 6}

Conclusiones 
La presente investigación ha buscado ofrecer un panorama teórico-empírico que abunde en el conocimiento del fenómeno jornalero haciendo un énfasis especial en la infancia indígena jornalera con el propósito de mostrar que, profundizar en el conocimiento del papel que estos niños ocupan en el fenómeno de la migración laboral jornalera y la reproducción económica de sus familias campesinas, es también profundizar en nuestro entendimiento de las cadenas globales de producción de mercancías y, por ende, de los mecanismos de producción y reproducción del capitalismo posfordista.

Los niños indígenas migrantes y jornaleros son un sujeto paradigmático del capitalismo tardío y la modernidad, pues en ellos se conjugan la explotación y la victimización, en plena era de los derechos humanos y las garantías individuales, de la mano del ensalzamiento neoliberal de la autonomía individual y la autosuficiencia.

En una era en que la legitimación de las grandes narrativas enfrenta una crisis y un declive, la infancia indígena y vulnerable representa una oportunidad para apuntalar los tambaleantes cimientos de los valores primordiales del Estado-nación, reafirmar identidades y construir subjetividades de acuerdo a los grandes ideales occidentalescapitalistas. La infancia se convierte así en un terreno fértil para hablar sobre la pureza, la inocencia y lo inmaculado, para salvaguardar los intereses nacionales al tiempo que es transformada en una arena desde la cual se pelean las batallas más idealistas que buscan reafirmar el triunfo de la razón, la escolarización, la modernidad, el desarrollo, el progreso, el individualismo, la autonomía y la industrialización como los pilares de la historia y la humanidad.

Al mismo tiempo, el estudio de la infancia nos abre novedosas posibilidades para aplicar y ampliar las reflexiones propuestas por teóricos y académicos del feminismo, la crítica poscolonial y los estudios subalternos en tanto que, habiendo sido construida como una categoría más de otredad, la niñez también representa todo aquello que debe ser relativizado, contestado, contextualizado e incluso resistido.

A lo largo de esta investigación se ha argumentado que investigar y reflexionar sobre la infancia trabajadora y migrante desde una perspectiva que reconozca a los niños como actores sociales móviles y sujetos de procesos y acontecimientos que 
tienen lugar no en paisajes socioculturales fragmentados e independientes, sino en espacios "jerárquicamente interconectados", nos abre la posibilidad de develar y analizar mejor las características y el funcionamiento de las "topografías del poder" (Gupta y Ferguson 1992). Es así que las experiencias de vida de los niños jornaleros migrantes cobran un mayor sentido como ventanas o puntos de inflexión a partir de los cuales nos es posible comprender complejos fenómenos como el éxodo campesino, las cadenas de producción posfordista o la explotación capitalista del mercado laboral agrícola contemporáneo.

Se postula asimismo que a través del estudio de la participación infantil en las cadenas de producción agrícola que podemos comprender algunos de los procesos más complejos de subjetivación, control y construcción del sujeto en el capitalismo tardío. Hemos visto por ejemplo que la presencia de los niños en los campos jornaleros junto con sus padres ha sido bien aprovechada por empresas y agricultores que, valiéndose de su estatura, su "delicadeza" o sus manos "ágiles", han creado patrones de trabajo sumamente eficientes y rentables que representan cuantiosos beneficios para las productoras agrícolas. Sucede entonces que a la división sexual y étnica que organiza el sector agroexportador, se añade una nueva diferenciación basada en la edad y el tamaño físico que también es aprovechada y explotada por el capital.

Ahora bien, el fenómeno del trabajo infantil no debe ser explicado de manera unilineal pues sus causas son múltiples y complejas. Entre ellas se cuentan tanto el deterioro del campo mexicano, la introducción de nuevos ideales de vida en las comunidades campesinas y la aplicación de políticas económicas neoliberales, como los cambios sucedidos en los patrones de trabajo y migración familiar indígenajornalera, así como el uso que de éstas hacen las empresas productoras.

Dado que las familias campesinas suelen incorporarse al trabajo agrícola como unidades productivas con el fin de adaptarse mejor a la creciente especialización del trabajo, para incrementar su producción y así maximizar los bajos ingresos, los beneficios para la empresa agrícola son grandes. Porque la organización y jerarquización ya establecida al interior de la familia garantiza la eficiencia y el buen funcionamiento de la misma, porque el pago a destajo alienta a la vez que garantiza la productividad y la intensificación del trabajo familiar e infantil y porque el patrón 
familiar de trabajo facilita la subcontratación, una de las estrategias más efectivas para la maximización de la producción y las ganancias a bajos costos.

A esto se suman los casos en los que los niños y niñas que no están trabajando en los surcos con sus padres, éstos se dedican a tareas que permiten la reproducción de la familia jornalera, como es la preparación de comida, el cuidado de los bebés o el acarreo de agua, liberando, por consiguiente, la mano de obra adulta para el trabajo propiamente agrícola. Es así que una parte fundamental del costo de la reproducción cotidiana de las familias que debería quedar cubierta por el empleador es transferida a los niños y su carga de trabajo es vista como algo normal.

Tenemos entonces que por la forma en que se dan las relaciones de trabajo en el interior de los campos jornaleros y por la naturaleza del mismo, el trabajo infantil suele ser visto como algo natural y quedar, por lo tanto, invsibilizado. A esto debemos sumar la normalización que se hace de los niños como sujetos pequeños, frágiles y dóciles que son idóneos para la realización de tareas delicadas y muy especializadas pero a las que, al mismo tiempo, se les otorga poca importancia o no son consideradas como parte fundamental de la producción agrícola, por lo que son escasamente remuneradas.

Los niños jornaleros son explotados por el capital transnacional como mano de obra barata, móvil y flexible que puede incluso ser utilizada y organizada de manera autónoma por sus cualidades y características. A esto se suma la responsabilidad económica que muchos niños deciden o no tienen más alternativa que compartir con sus parientes para lograr la supervivencia familiar y que también es un imperativo que es bien aprovechado por los empresarios agrícolas, que saben de las carencias y las necesidades que enfrentan estas familias. Por lo tanto, a los ojos del capital, los niños no serían distintos a cualquier otro individuo capaz de vender su fuerza de trabajo, de no ser porque al tiempo que su trabajo es altamente valorado para ciertas tareas productivas, éste es depreciado en términos salariales. Esto sucede porque los niños jornaleros son Orientalizados, es decir, infantilizados, construidos en el discurso de la productividad y las relaciones laborales como individuos inmaduros e incompletos, definidos por rasgos esenciales y cualidades naturales, que hacen que sus cargas extras de trabajo no sean consideradas como relevantes para el ciclo productivo y, por lo tanto, la magnitud y la importancia de su participación es depreciada e ignorada. 
Al mismo tiempo, como sujetos de políticas públicas victimizadoras y meramente asistencialistas, los niños son perpetuados como sujetos subalternos, carentes de agencia y de la capacidad de tomar decisiones racionales. Desde las políticas públicas dedicadas a la atención de la infancia marginada o vulnerable se suele entender a los niños jornaleros como meras víctimas. De sus padres, de las costumbres ancestrales, de sus culturas o bien del trabajo jornalero. Esta es una visión que no sólo contribuirá a mantenerlos en un estado de otredad y subalternidad permanente y que además resulta favorable para la lógica del capitalismo posfordista, que busca sujetos dóciles, flexibles y auto-disciplinados; sino que, al entenderlos fundamentalmente como víctimas pasivas y casi exclusivamente en base a sus problemas y sus carencias, las políticas públicas construyen a los niños indígenas y jornaleros como individuos desvalidos, que deben ser acogidos y protegidos por el estado y sus instituciones, al tiempo que sus familias deben enfrentar el reto de romper "el círculo vicioso de la pobreza" por sí mismas y utilizando los apoyos económicos condicionados que el gobierno les proporciona como una herramienta para la superación personal. Se reproduce así la idea de que los jornaleros son individuos necesitados y desvalidos, regidos por una cultura irracional, que deben ser educados y asistidos, pero que a la vez deben aprovechar los beneficios que su inserción a la modernidad supuestamente les proporciona para ser plenos partícipes de la economía, el consumo y la sociedad capitalista.

Las transformaciones económicas, tecnológicas, ideológicas y políticas que han propiciado y sostenido el desarrollo de la moderna agricultura de exportación, además de provocar un cambio en las formas de trabajo agrícola, han promovido también cambios en el comportamiento, los estilos de vida y los valores de quienes constituyen su nuevo ejército laboral. Pero, ise trata de un cambio que propone nuevas alternativas a los antiguos mecanismos de subordinación o por el contrario contribuye a fortalecerlos y perpetuarlos? ¿Son los jornaleros migrantes un sujeto con nuevas posibilidades de agencia y resistencia o son sólo la expresión de una nueva modalidad de antiguas formas de explotación?

La propuesta de esta investigación es que una antropología de la infancia jornalera puede contribuir significativamente a dar respuesta a estas interrogantes en tanto que los niños también son actores sociales de estos fenómenos y las 
problemáticas que han originado. Los niños también participan y contribuyen a construir las "luchas culturales" (Ong 1991) que los jornaleros sostienen contra las nuevas y variadas formas de dominación que enfrentan y para encontrar nuevas formas de contender con la realidad social. Los niños jornaleros también contribuyen a la construcción y al enriquecimiento de la conciencia práctica que permite a las poblaciones indígenas contemporáneas contender y resistir la explotación y la sujeción, creando novedosas producciones culturales que le otorgan nuevos sentidos al individuo y a la comunidad.

\section{Bibliografía}

Aguirre Beltrán, Gonzalo 
1957 El proceso de aculturación. UNAM, México, D.F.

1973 Teoría y práctica de la educación indígena. SEP, México, D.F.

Aguirre Beltrán, Gonzalo (prólogo y selección)

1970 Antología de Moisés Sáenz. Ediciones Oasis, México, D.F.

Aragonés, Ana María

2004 "Migración y explotación de la fuerza de trabajo en los años noventa: saldos del neoliberalismo", en: Blanca Rubio (coord.) El sector agropecuario mexicano frente al nuevo milenio. UNAM-Plaza y Valdés, México, D.F. Pp: 239268.

Ariès, Phillipe

1962 Centuries of Childhood: A Social History of Family Life. Vintage Books, New York.

Asensi, Manuel

2006 "Spivak o el mundo subalterno". Documento electrónico disponible en: http://salonkritik.net

Badiwala, Mithesh

1998 "Child labour in India: causes, governmental policies and the role of education". Versión electrónica disponible en: http://www.geocities.com/CollegePark/Library/9175/inquiryl.htm

Barrón, Antonieta

1999 "Las migraciones en los mercados de trabajo de cultivos intensivos en fuerza de trabajo: un estudio comparativo", en: Agricultura de exportación en tiempos de globalización: el caso de las hortalizas, frutas y flores. Juan Pablos/UACH/UNAM, México, D.F. Pp: 255-283.

Berman, Marshall

1989 Todo lo sólido se desvanece en el aire: la experiencia de la modernidad. Siglo Veintiuno Editores, México, D.F.

Besserer, Federico y Rocío Gil

2008 "¿Desde Babel o hacia Babel??", en: Paolo Corvo y Raúl Enríquez Valencia (eds.), Babele e Dintorni: fra catastrofismi e nuovi percorsi di senso. Mauro Pagliai, Firenze. Pp: 79-87.

Bey, Marguerite

2001 "Relación campo-ciudad: desarrollo regional y la nueva especialidad social", en: Beatriz Canabal Cristiani (coord.), Los caminos de la montaña: formas de reproducción social en la montaña de Guerrero, UAM/CIESAS/Porrúa, México, D.F.

2003 "The Mexican Child: From Work with the Family to Paid Employment". Childhood, 10, pp: 287-299. 
Bluebond-Langer, Myra \& Jill Korbin

2007 "Challenges and Opportunities in the Anthropology of Childhoods: An Introduction to "Children, Childhoods and Childhood Studies". American Anthropologist, Vol. 109, No. 2. pp: 241-246.

Canabal, Beatriz

2002 "Estrategias de sobrevivencia y el contorno regional", en: Beatriz Canabal Cristiani (coord.), Los caminos de la montaña: formas de reproducción social en la montaña de Guerrero, UAM/CIESAS/Porrúa, México, D.F.

CEPAL-FAO

1998 Agroindustria y pequeña agricultura: vínculos, potencialidades y oportunidades comerciales. ONU, Santiago de Chile.

Chávez Román, José Antonio

2004 "Marginación, desarrollo y manejo de los recursos naturales en la Montaña de Guerrero", en: Beatriz Canabal Cristiani y José Joaquín Flores Félix (coords.) Montañeros: actores sociales en la Montaña del estado de Guerrero. UAM/Universidad Autónoma de Chapingo/El Atajo Editores, México, D.F. Pp: 15-59.

Dehouve, Danièle

2001 Cuando los banqueros eran santos: historia económica y social de la provincia de Tlapa, Guerrero. Universidad Autónoma de Guerrero, México, D.F.

Echánove Huacuja, Flavia

2004 "La expansion de las hortalizas en los años noventa y su vínculo con la agroindustria hortícola", en: Blanca Rubio (coord.) El sector agropecuario mexicano frente al nuevo milenio. UNAM/Plaza y Valdés, México, D.F., Pp: 207-235.

Escobar, Arturo

1988 "Power and Visibility: Development and the Invention and Management of the Third World". Cultural Anthropology, Vol. 3, No. 4, pp. 428-443.

Fabian, Johannes

1983 Time and the Other: How Anthropology Makes Its Object. Columbia University Press, New, York.

Faulstich Orellana, Marjorie, Barrie Thorne, Anna Chee, Wan Shun Eva Lam

2001 "Transnational Childhoods: The Participation of Children in Processes of Family Migration". Social Problems, Vol. 48, No. 4, pp: 572-591.

Favela Alejandro, Miriam Calvillo, Alfonso León, Israel Palma y Pablo Martínez

2003 El combate a la pobreza en el sexenio de Zedillo. UAMI, Plaza y Valdés, CEDIOC, México, D.F. 
Foucault, Michel

1978a Vigilar y castigar. Siglo Veintiuno, México, D.F.

Fraser, Nancy

1989 "Talking about Needs: Interpretive Contests as Political Conflicts in WelfareState Societies". Ethics, Vol. 99, No.2, pp: 291-313.

2003 "¿De la disciplina hacia la flexibilización? Releyendo a Foucault bajo la sombra de la globalización". Revista Mexicana de Ciencias Políticas y Sociales. enero-abril, año/vol. XLVI, No. 187, pp: 15-33.

Geertz, Clifford

1989 El antropólogo como autor. Paidós Studio, Barcelona.

Gélis, Jaques

1990 "La individualización del niño", en: Phillipe Ariès y Georges Duby (coords.), Historia de la vida privada: el proceso de cambio en la sociedad del siglo XVI a la sociedad del siglo XVIII. Vol. 5. Taurus, Buenos Aires. Pp: 311 -329.

Giraldo Díaz, Renato

2006 "Poder y resistencia en Michel Foucault". Tabula Rasa, No. 004, pp: 103-122.

Glockner, Valentina

2008 De la montaña a la frontera: identidad, representaciones sociales y migración de los niños mixtecos de Guerrero. El Colegio de Michoacán. Zamora.

Goldman, Julie

1999 "Interpretaciones de la producción agroindustrial: el control de calidad en la industria frutícola chilena", en: Grammont, Hubert C, Manuel Ángel Gómez Cruz, Humberto González y Rita Schwentesius (coords.) Agricultura de exportación en tiempos de globalización: el caso de las hortalizas, frutas y flores. Juan Pablos/UACH/UNAM, México, D.F. Pp: 341-378.

Grammont, Hubert C.

1999 "La modernización de las empresas hortícolas y sus efectos sobre el empleo", en: Grammont, Hubert C, Manuel Ángel Gómez Cruz, Humberto González y Rita Schwentesius (coords.) Agricultura de exportación en tiempos de globalización: el caso de las hortalizas, frutas y flores. Juan Pablos/UACH/UNAM, México, D.F. Pp: 3-22.

Grammont, Hubert C, Manuel Ángel Gómez Cruz, Humberto González y Rita Schwentesius (coords.)

1999 Agricultura de exportación en tiempos de globalización: el caso de las hortalizas, frutas y flores. Juan Pablos/UACH/UNAM, México, D.F.

Goodman, David y Michael Redclift

1991 Refashioning Nature: Food, Ecology and Culture. Routledge, New York, NY.

Gupta, Akhil y James Ferguson 
1992 "Beyond "Culture": Space, Identity, and the Politics of Difference". Cultural Anthropology, Vol. 7, No. 1, pp: 6-23.

Charlotte Hardman

1973 "Can there be an anthropology of children?". Journal of the Antrhropology Society of Oxford. 4(1):85-99.

Harvey, David

2004 La condición de la posmodernidad: investigación sobre los orígenes del cambio cultural. Amorrortu, Madrid.

Herrera y Ayala

2006 "Debaten expertos sobre el problema del trabajo infantil", en: Gaceta Universitaria del 18 de junio de 2007, No. 3,993, UNAM, México, D.F.

Human Rights Watch

1996 The Small Hands of Slavery: Bonded Child Labour in India. Human Rights Watch, New York.

Illich, Ivan

1978 La sociedad desescolarizada. Posdata, México, D.F.

1984a "The Seamy Side of Charity", en: Celebration of Awareness: A Call for Institutional Revolution. Penguin Books, Singapore. Pp. 47-58.

1984b Celebration of Awareness: A Call for Institutional Revolution. Penguin Books, New York.

1990 "Needs". Documento electrónico: http://www.davidtinapple.com/illich.

INEGI

2000 Tabulados básicos. Estados Unidos Mexicanos. XII Censo General de Población y Vivienda. INEGI y Gobierno Federal, México, D.F. Documento electrónico: http://www.inegi.gob.mx

James, Allison

2007 "Giving Voice to Children's Voices: Practices and Problems, Pitfalls and Potentials". American Antrhopologist. Vol. 109, No. 2, pp: 261-272.

Jameson, Fredric

2001 Teoría de la Posmodernidad. Trotta, Madrid.

Lara, Sara

1991 Las obreras agrícolas: un sujeto social en movimiento. Nueva Antropolgía. Vol XI:39, pp. 107-111.

2008 "Espacio y territorialidad en las migraciones rurales. Un ejemplo en el caso de México", en: Pablo Castro Domingo (coord.) Dilemas de la migración en la sociedad posindustrial. Porrúa/UAM/Universidad Autónoma del Estado de México/CONACYT, México, D.F. Pp: 17-38.

Lomnitz, Larisa 
1974 Cómo sobreviven los marginados. Siglo Veintiuno, México, D.F.

Maldonado, Benjamín

2002 Los indios en las aulas: dinámica de dominación y resistencia en Oaxaca. INAH, México, D.F.

Manzanos, César

2002 La infancia migrante explotada: mercantilización y utilización política. Presentado en el Foro Invisibilidad y Conciencia: Migración Interna de niñas y niños jornaleros agrícolas en México, México, D.F. Documento electrónico: http://www.vam.mx/cdi/foroinvisibilidad/conferencistas/cesarmanzanos.pdf

Maureira, Fernando

2002 "Trabajo infantil. Algunas consideraciones desde la antropología". Revista Austral de Ciencias Sociales. No.6, pp. 113-124. Versión electrónica.

Mankekar, Purnima

1997 "To Whom Does Ameena Belong?: Towards a Feminist Analysis of Childhood and Nationhood in Contemporary India". Feminist Review, No. 56, pp: 26-60.

Miranda, Adela e Ibis Sepúlveda

2008 Piececitos transhumantes: los niños jornaleros migrantes en México, México, D.F.

Moscoso, María Fernanda

2008 "Nuevos sujetos, nuevas voces: èhay lugar para la infancia en el pensamiento transnacional?". En: Enrique Santamaría (Ed.), Retos epistemológicos de las migraciones transnacionales. Anthropos, Barcelona. Pp: 261-281.

Munn, Nancy

1992 "The Cultural Anthropology of Time: A Critical Essay". Annual Review of Anthropology, Vol. 21, pp: 93-123.

Muñoz, Maurilio

1963 Mixteca-Nahua-Tlapaneca. INI, México, D.F.

Nemecio, Isabel Margarita

2004 "Niños en la economía doméstica de la Montaña de Guerrero", en: Beatriz Canabal Cristiani y José Joaquín Flores Félix (coords.) Montañeros: actores sociales en la Montaña del estado de Guerrero. UAM/Universidad Autónoma de Chapingo/El Atajo Editores, México, D.F. Pp: 101-128.

2006 Migrar o Morir: el dilema de los jornaleros agrícolas de la montaña de Guerrero. Tlachinollan, Centro de Derechos Humanos de la Montaña. México, D.F.

Ocampo, Sergio

2005 Metlatónoc, el imperio de la pobreza. Crónica de la visita del presidente mexicano Vicente Fox. Documento electrónico: 
http://www.rebelion.org/noticia.php?id=18256, accesado el 30 de diciembre del 2005.

2007 "En México no se cumple la ley sobre trabajo infantil: relator de la ONU". La Jornada, miércoles 7 de marzo de 2007.

Ong, Aihwa

1987 Spirits of Resistance and Capitalist Discipline: Factory Women in Malaysia. State University of New York Press.

1991 "The Gender and Labor Politics of Postmodernity". Annual Review of Anthropology, Vol. 20, pp: 297-309.

Pérez Villalba, Elba

2005 "La fuerza de trabajo migrante mexicana, de procedencia rural, ante el mercado laboral norteamericano", en: Anita Brumer y Diego Piñeiro (coords.) Agricultura Latinoamericana: Novos arranjos e velhas questoes. Universidade Federal do Rio Grande do Sul. Pp: 379-391.

Podestá, Rossana

2004 Encuentro de miradas, hacia nuevos modelos para el estudio de las representaciones sociales infantiles nahuas y occidentales de su territorio: Tesis doctoral inédita, Universidad Autónoma de México-Iztapalapa, Departamento de Ciencias Antropológicas, México, D.F.

Podestá, Rossana y niños y niñas nahuas

2002 Nuestros Pueblos de Hoy y Siempre. El Mundo de las Niñas y los Niños Nahuas de México a Través de sus Propias Letras y Dibujos. Benemérita Universidad Autónoma de Puebla-Instituto de Ciencias Sociales y HumanidadesVicerrectoría de Investigación y Estudios de Posgrado, México, D.F.

Polet, François y Françoise Houtard

1999 "La pauvreté à l'aube du troisième millénaire". Alternatives Sud, cahiers trimestriels, Vol. 6.

Poder Ejecutivo Federal y Secretaría de Educación Pública

1996 Programa de desarrollo educativo 1995-2000. PEF-SEP, México, D.F.

PRONJAG

2000 Jornaleros Agrícolas. Secretaría de Desarrollo Social, México, D.F.

2002 "Programa para contribuir al ejercicio de los derechos de niñas y niños, hijos de jornaleros agrícolas, y al desaliento del trabajo infantil (Proceder)". Presentado en el Foro Invisibilidad y Conciencia: Migración Interna de niñas y niños jornaleros agrícolas en México, México, D.F. Documento electrónico: http://www.uam.mx/cdi/foroinvisibilidad/trabajo/pronjag.pdf. Accesado el 26 de octubre del 2005.

Quinteros, Graciela

2005 El arte, la imaginación y el juego: fronteras indómitas y espacios mediadores 
de lo esencialmente humano. Documento electrónico:

http://www.xoc.uam.mx/utilerias/search2.html Accesado el 7 de febrero del 2006.

Ramírez, Rafael

1982 La escuela rural mexicana. SEP-FCE, México, D.F.

Ramos, Samuel

1979 El perfil del hombre y la cultura en México. Espasa Calpe, México, D.F.

Raynolds, Laura

1997 "Restructuring National Agriculture, Agro-Food Trade and Agrarian Livelihoods in the Caribbean", en: Goodman y Watts (comps.), Globalizing Food: Agrarian Questions and Global Restructuring. Routledge, New York.

Reynolds, Pamela

1991 Dance Civet Cat: Child Labour in the Zambesi Valley. Ohio University Press, Atenas.

Rodríguez Solera, Rafael (coord.)

2007 Menores jornaleros migrantes: derechos, educación y cultura en el Valle del Mexquital. Universidad Autónoma del Estado de Hidalgo/Editorial Praxis, México, D.F.

Rojas, Teresa

2006 "Las niñas y los niños jornaleros migrantes en México: condiciones de vida y trabajo", en: III Conferencia de la Red Latinoamericana y del Caribe de Childwatch International, del 17 al 19 de julio, México.

Rosen, David

2007 "Child Soldiers, International Humanitarian Law, and the Globalization of Childhood". American Antrhopologist. Vol. 109, No. 2, pp: 296-306.

Roy, P.

1972 Contract Farming and Economic Integration. Interestate Press, Danville, III.

Rubio, Blanca

2004 "El sector agropecuario mexicano en los años noventa: subordinación desestructurante y nueva fase productiva", en: Blanca Rubio (coord.) El sector agropecuario mexicano frente al nuevo milenio. UNAM/Plaza y Valdés, México, D.F., Pp: 17-45.

Rudnyckyj, Daromir

2004 "Technologies of Servitude: Governmentality and Indonesian Transnational Labor Migration". Anthropological Quarterly, Vol. 77, No.3, pp: 407-434. 
Said, Edward

1990 Orientalismo. Libertarias, Madrid.

Saldaña, Adriana

2008 "La experiencia de una agroempresa estadounidense en la producción de hortalizas de exportación en Morelos", en: Pablo Castro Domingo (coord.) Dilemas de la migración en la sociedad posindustrial.

Porrúa/UAM/Universidad Autónoma del Estado de México/CONACYT, México, D.F. Pp: 65-81.

Sánchez, Kim

2001 Los niños en la migración familiar de jornaleros agrícolas. En La infancia vulnerable de México en un mundo globalizado, coordinado por Norma Del Río. UAM-UNICEF, México, D.F. Pp. 79-94.

2005 "La experiencia de niños y niñas en la migración estacional de jornaleros agrícolas en México", en: Anita Brumer y Diego Piñeiro (coords.) Agricultura Latinoamericana: Novos arranjos e velhas questoes. Universidade Federal do Rio Grande do Sul. Pp:361-377.

2006 Los capitanes de Tenextepango: un estudio sobre intermediación cultural. Universidad Autónoma del Estado de Morelos-Porrúa. México, D.F.

Schepper-Hughes, Nancy and Carolyn Sargent (eds.)

1998 Small Wars: The Cultural Politics of Childhood. University of California Press, Berkeley.

SEDESOL - UNICEF

2006 Diagnóstico sobre la condición social de las niñas y niños migrantes internos, hijos de jornaleros agrícolas. SEDESOL-UNICEF, México, D.F.

SIPAZ (Servicio Internacional Para la Paz)

S/F "Guerrero en Datos". Documento electrónico:

http://www.sipaz.org/fini esp.htm

Tlachinollan, Centro de Derechos Humanos de La Montaña

2007 "Caso del niño David Salgado", en:

www.tlachinollan.org/casos/David\%20salgado/david.htm

Toren, Christina

2007 "An Anthropology of human development: what difference does it make?", en: Alan Fogel and Stuart Shanker (eds.) A Dynamic Systems Approach to the Life Sciences. Cambridge University Press, Cambridge.

Turati, Marcela, Laura Toribio y Lucía Irabién

2007 "La muerte se empaca en guacales". Excélsior, 27 de junio de 2007.

USDA (United States Agricultural Department) 
1999 Farmer's Use of Marketing and Production Contracts. (AER-747), Washington. http://www.usda.gov/wps/portal/!ut/p/_s.7_0_A/7_0_1OB? navtype=SU\&navid $=A G R I C U L T U R E$

Villalpando, Alejandra

2005 Políticas públicas en la atención a jornaleros migrantes. Foro La Educación de Menores Jornaleros Migrantes en el Valle del Mezquital, Hidalgo. Pachuca, Hidalgo. Pp. 18-26.

Zedillo, Ernesto

1997 "Versión estenográfica de las palabras del presidente Ernesto Zedillo, durante la presentación del Programa PROGRESA, en donde suscribió, junto con el gobernador Jesús Murillo, el Acuerdo de Coordinación entre el Gobierno Federal y el Gobierno del Estado para Apoyar las Acciones del Programa PROGRESA, en la escuela primaria federal Adolfo López Mateos, de la comunidad rural "Emilio Hernández" La Florida, perteneciente a este municipio". En: http://zedillo.presidencia.gob.mx/pages/disc/ago97/06ago97$\underline{1 . h t m l}$ 


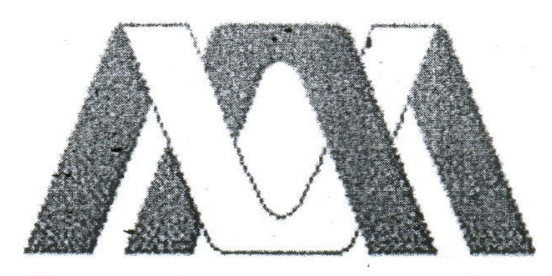

Casa abierta al tiempo

\section{¿VÍCTIMAS O TRABAJADORES?}

Niños jornaleros y producción

de subjetividades en el capitalismo tardío

Tesina que para obtener el grado de Maestra en Ciencias Antropológicas presenta Valentina Glockner Fagetti

Universidad Autónoma Metropolitana, Iztapalapa.

Directora: Dra. Margarita Zárate Vidal Asesor: Dr. Federico Besserer Alatorre Asesora: Dra. Adela Miranda

México, D.F., Junio del 2009

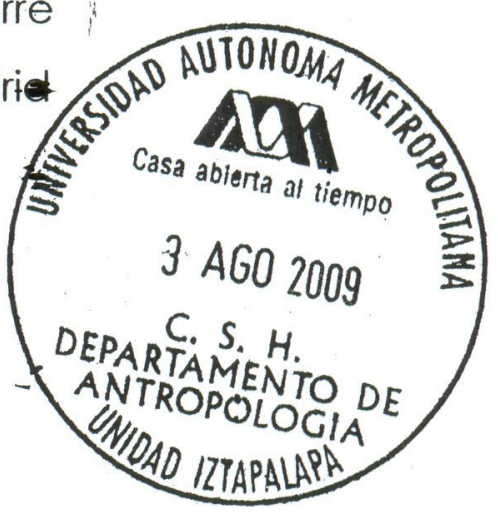

